\title{
PRESSURIZED FLUIDIZED-BED HYDRORETORTING OF EASTERN OIL SHALES
}

Progress Report for the Period September-November 1991

By

F.S. Lau

M. C. Mensinger

M. J. Roberts

D. M. Rue

December 1991

Work Performed Under Contract No.: DE-AC21-87MC11089

For

U.S. Department of Energy

Office of Fossil Energy

Morgantown Energy Technology Center

Morgantown, West Virginia 26505

$B y^{\prime}$

Institute of Gas Technology

Chicazo, Mlinois 60616

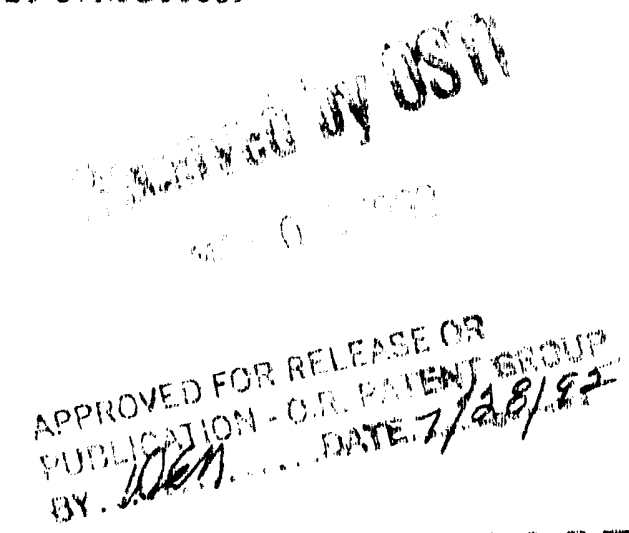

TECHNICAL INFORMATION CENTER

MASTER OFFICE OF SCIENTIFIC AND TECHNICAL INFORMATION UNITED STATES DEPARTMENT OF ENERGY

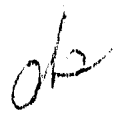




\section{DISCL.AIMER}

This report was prepared as an socount of work eponcored by an agency of the United States povermment. Nelther the United Stalas Government nor any agency thereof, nor any of their employese, makes any warranty, expreses or impliad, or esesumes uny begal liability or responslbility for the accuracy, complatences, or usefulness of eny information, eppuratuls, product, or proseses dicclosed, or represents that the use would not inininge privately owned righte. Feferance hereln to any epeclilc commerclal product, process, or enrvice by trade name, tredemark, manufecturer, or otherwise, does not necessarly constltute or imply tis endorsement, recommendation, or tevoring by the United states Covernment or any agency thereof. The vlews and opinions of author expresed herein do not necesesully state or reflect those of the United States Covemment or any agoncy thereot.

Printed in the United States of America

Avaliable from

National Technical Information Service

U.S. Department of Commerce

5285 Port Royal hoad

Springfield, VA 22161

NTIS price codes

Printed copy: 403

Microfiche copy: A01 


\title{
PRESSURIZED FLUIDIZED-BED HYDRORETORTING OF EASTERN OIL SHALES
}

Progress Report for the Period September-November 1991

\author{
By \\ F. S. Lau \\ M. C. Mensinger \\ M. J. Roberts \\ D. M. Rue
}

December 1991

Work Performed Under Contract No.: DE-AC21-87MC11089

\author{
For \\ U.S. Department of Energy \\ Office of Fossil Energy \\ Morgantown Energy Technology Center \\ P.O. Box 880 \\ Morgantown, West Virginia 26505
}

Institute of Gas Technology

IIT Center, 3424 S. State Street

Chicago, Illinois 60616 


\section{EXECUTIVE SUMMARY}

This report presents the work performed during the program quarter from September 1 through November 30, 1991, under U.S. Department of Energy (DOE) Contract No. DE-AC21-87MC11089 for the project "Pressurized Fluidized-Bed Hydroretorting (PFH) of Eastern Oil Shales." The Institute of Gas Technology (IGT) is the prime contractor for the overall program extension to expand the PFH data base to beneficlated shales. Four universities are working with IOT as subcontractors; their responsibilities and achievements in the program are discussed below in the appropriate tasks.

Some of the tasks in the original program were not continued in the current program extension. The task achlevements discussed below represent. the active tasks of the program.

In Subtask 3.7 (Innovative Reactor Concept Testing), IGT completed the construction of the cracking-combustion unit. Shakedown tests in this laboratory-scale batch unit will be initiated next quarter.

In Subtask 3.8 (Niche Market Studies), all of the equipment necessary for characterizing asphalts produced from PFH processing of beneficiated shale have been ordered and received. IGT will begin the asphalt screening tests next quarter.

The University of Alabama Mineral Resources Institute (MRI) is responsible for the work being conducted in Task 4 (Beneficiation Research).

In Subtask 4.1.4 (Grinding-Flotation Circuit Design), MRI continued work on determining methods for reducing stirred ball mill grinding costs. As part of this effort, MRI ground several hundred kilograms of Alabama shale to - 100 , -200 , and -460 mesh for the tests. Also, hydrocycloning tests were conducted on these samples of shale. The results of these tests showed that, for several feed solids concentrations, the $d_{s 0}$ of the cyclone overflow product can be in the 11 to $12 \mu \mathrm{m}$ range, thus reducing the quantity of material reporting as stirred ball mill feedstock. However, the cyclone underflow products would require thickening to yield stirred ball mill feedstock in the 45 to 50 percent solids range required.

In Subtask 4.4 (Integrated Grinding and Flotation), the University of Kentucky Center for Applied Energy Research (UK-CAER) conducted column flotation tests in the $5.1 \mathrm{-cm}(2-1 \mathrm{nch})$ diameter $6.1-\mathrm{m}$ high (20-ft) Ken-Flote column. Among the operating conditions tested were the froth height, slurry feed rate, wash water addition rate, and refloating the rougher concentrate. Fuel oil and pine oil were also tested to determine their effect on organic carbon recovery. In the rougher stage, the recovery of carbon was 54.7 percent with a concentrate grade of 47.8 percent carbon. Cleaner flotation of this product yielded 54.8 percent carbon recovery with a concentrate grade of 56.8 percent carbon. The overall recovery for this two-stage process was 30.0 percent with a final grade of 56.8 percent carbon. These results show that a cleaner flotation can increase the carbon content of the final product, however, the overall recovery was poor. This test was conducted using the static sparger for fine bubble generation with a concentration of $1 \mathrm{~kg}$ of pine oil 
per metric ton of shale. To lmprove the overall recovery it would be necessary to significantly increase the recovery in the rougher flotation stage.

In Subtask 4.5. (Evaluation of Different Grinding Media), MRI conducted stirred ball mill tests with the Molinex Option with sand, and the John Option with sand and steel media. Both types of media were $1.1 \mathrm{~mm}$ in diameter. The results show that for ultra-fine grinding to a $d_{\infty}$ of 6 pm or less, sand media requires less energy than steel media. For a smaller size reduction ratio, in which the product $d_{s}$ is between 6 and $9 \mu \mathrm{m}$, steel media requires less energy.

In Subtask 4.6.1. (OII Agglomeration and Pelletizing), MRI conducted shale agglomeration tests with different chemicals, such as n-pentane. The results show that agglomerate formation has not yet been achieved.

In Subtask 4.6.2 (Bioflocculation of Kerogen), the University of Nevada, Reno (UN) conducted tests to determine the effects of $\mathrm{pH}$ and microorganism concentration on flocculation. The flocculation and settling rate of kerogen increases with the addition of Mycobacterfum phle1. At a pH of 4.6, no significant difference in the settling rate was observed after 5 minutes with and without organisms. However, for settling times of less than 5 minutes, bacterial addition has a positive effect on initial flocculation and setting.

In Task 5 (Operation of PFH on Beneficiated Shale), IGT completed equipment modifications to the bench-scale fluidized-bed unit. These improvements include the addition of new feed and residue screw controllers and counters, modification of the residue screw flights, and modification of the environmental sampling train to ensure that only Teflon-coated surfaces come in contact with the acid and base scrubs. Bench-scale tests with beneficiated shale will begin next quarter.

In Subtask 6.2.2 (Wastewater Treatability), Tennessee Technological University (TTU) continued acclimating microorganisms to 4-methyl pyridine. Biological treatability studies continued with phenol and methyl ethyl ketone (MEK). In batch treatability studies with phenol, biological stabilization of phenol began within 10 hours and was completed for reactors containing as much as $450 \mathrm{mg} / \mathrm{L}$ within 58 hours. In the batch treatability studies with MEK, biodegradation began within the first 4 hours of the experiment and was completed for reactors containing as much as $250 \mathrm{mg} / \mathrm{L}$ within about 32 hours.

In Subtask 6.4.3. (Plant Energy Optimization), TrU focused on the detailed exergy analysis of the PFH plant and initiated the thermoeconomic evaluation. A preliminary analysis of the PFH plant design showed an overall exergetic efficiency of 84.9 percent for the total plant. TTU also inftiated development of the computer software, the cost balances, and the equations required to complete the thermoeconomic evaluation.

In Task 7 (Sample Procurement, Preparation, and Characterization), MRI collected about 9 tons of shale from a site in Alabana for use by the program participants. This bulk sample was shipped to Michigan lechnological University and beneficiated in MTU continuous equipment. Portions of the beneficiated shale have been shipped to IGT, UK-CAER, and MRI. 
In Task 8 (Project Management and Reporting), IGT personnel visited the carapuses of TTU, UK-CAER, and MRI during the quarter. IGT continued to monitor the progress and activities of the subcontractors working in the program via telephone and written reports. Also, several papers were presented by IGT personnel at the 1991 Eastern Dil Shale Symposium (held November 12-14 in Lexington, Kentucky) on various project.related topfcs. Papers were also presented by MRI, TTU, and UN on project activities. 
TABLE OF CONTENTS

$\underline{\text { Page }}$

INTRODUCTION

ACHIEVEMENTS

Task 3. Testing of Process Improvement Concepts 2

Task 4. Beneficiation Research 4

Task 5. Operation of PFH on Beneficiated Shale 25

Task 6. Environmental Data and Mitigation Analyses 25

Task 7. Sample Procurement, Preparation, and Characterization 37

Task 8. Project Management and Reporting 43

$\begin{array}{ll}\text { FUTURE PLANS } & 43\end{array}$

$\begin{array}{ll}\text { ACKNOWLEDGMENTS } & 43\end{array}$

Appendix A. Results of the Preliminary Exergetic Evaluation of the PFH Process Plant by Tennessee Technological University

Table A-1. Thermodynamic Properties of Streams in the PFH Plant

Table A-2. Heat Loss, Power Supplied, Exergy

Destruction Flow Rate, Exergy Destruction Ratio, Exergy Destruction to Shale Exergy Ratio, and

Exergetic Efficiency for Plant Components

Table A-3. Steam Generation/Consumption: (positive values mean steam generation, negative values mean steam consumption)

Appendix B. Development of Thermoeconomic Factors for the PFH Plant by Tennessee Technological University 
Figure No.

Page

4-1 Effect of Cyclone Pressure and Feed Size at

High Feed Solids ( 27 to 31 Percent)

4-2 Effect of Cyclone Pressure and Feed Size at Medium Feed Solids ( 12.5 to 15 Percent)

4-3 Effect of Cyclone Pressure and Feed Size at Low Feed Solids ( 4.8 to 6.8 Percent)

4-4 Continuous Grinding and Sizing Circuit

4-5 Effect of Media Type on the Shape of Particle Size Distribution at Similar Product Median Size

4-6 Effect of Mill Type on the Shape of Particle Size Distribution at Similar Product Median Size

4-7 Effect of Media Type on the Shape of Particle size Size Distribution at Similar Median Product Size

4-8 Alternative Oil Agglomeration and Pelletizing Schemes

4-9 Settling Characteristics of Beneficiated Alabama Shale (1.0 wt solids, $\mathrm{pH} 7.3, \underline{\text { phlel }}-70 \mathrm{ppm}$ )

4-10 Betting Characteristics of Beneficiated Alabama Shale ( 1.0 wt solids, $\mathrm{pH} 4.6, \underline{\mathrm{M}}$ phlei $=70 \mathrm{ppm}$ )

4-11 Settling Characteristics of Beneficiated Alabama Shale (1.0 wt solids, pH $9.4 \underline{\text { phlei }}-70 \mathrm{ppm}$ )

4-12 Effect of $\mathrm{pH}$ on Settling Characteristics of Beneficiated Alabama Shale (10 min settling time, $\underline{\text { shlei }}=70 \mathrm{ppm}$, 1.0 wt solids)

4-13 Scanning Electron Micrograph of Kerogen With Mycobacterium phle1

4-1.4 Effect of $\mathrm{pH}$ on Settling Characteristics of Freshly Prepared Beneficlated Alabama Shale (5 min settling time, $\underline{\text { phlei }}=100 \mathrm{ppm}, 0.5$ wt solids)

6.1 COD and Phenol vs. Time For Phenol Batch Experiment 6 (The Initial Phenol Concentrations were 50, 100, and $250 \mathrm{mg} / \mathrm{L}$ ) 


\section{LIST OF FIGURES (continued)}

Figure No.

Page

6-2 COD and Phenol vs. Time For Phenol Batch Experiment 6 (The Initial Phenol Concentration was $100 \mathrm{mg} / \mathrm{L}$ )

6-3 COD and Phenol vs. Time for Phenol Batch Experiment 6 (The Initial Phenol Concentration was $250 \mathrm{mg} / \mathrm{L}$ )

6-4 COD and Phenol vs. Time For Phenol Batch Experiment 6 (The Initial Phenol Concentration was $450 \mathrm{mg} / \mathrm{L}$ )

6-5 MEK vs. Time For MEK Batch Experiment 1 (The Initial MEK Concentrations were 50,100 , and $250 \mathrm{mg} / \mathrm{L}$ )

6-6 Flow Diagram of the PFH Plant

6-7 Flow Diagram of the Hydrogen Plant

7-1 Carbon:Density:011, MTU Column Cell vs. MRI Mechanical Cell Data

7-2 Flowsheet for Continuous Processing of Alabama Oil Shale at MTU 
Table No.

$\underline{\text { Page }}$

4-1 Size Consist of Coarse-Grinding Circult Discharges (Stirred Ball Mill Feed)

4-2 Cycloning - 100 Mesh Alabama Shale and Recleaning the Cyclone Underflow Product

4-3 Effect of Cyclone Feed Solids at 20 psig

4-4 Effect of Cyclone Feed Pressure at 6.18 Feed Solids 9

4-5 Prediction of Grinding Energy Required Based on Modified Charles Relationships for Various Media Combinations With Alabama Shale Rougher Concentrate

4-6 Product $d_{50}$ Values for Mill-Media System 1.4

6-1 Comparison of Phenol Batch Experiments 2 Through 6

7-1 Analyses of Alabama Oil Shale Head Samples 38

7-2 Comparison of Flotation Results on MrU Sample Ground to 3 Different Size Consists

7-3 Summary of MTU Flotation Results Based on Density Analyses of Samples

7-4 Average Material Balances for the MTU Packed Column Cell and the Deister Column Cell

7-5 Analysis of Head Sample of Total Concentrate Produced at MTU 
The Devonian oil shales of the Eastern United States are a significant domestic energy resource. The overall objective of the multi-year program, initiated in October 1987 by the U. S. Department of Energy (Contract No. DEAC21-87MC11089), is to perform the research necessary to develop the pressurized fluidized-bed hydroretorting ( $P F H$ ) process for producing oll from Eastern oil shales. The program also incorporates research on technologies in areas such as raw shale preparation, beneficiation, product separation, and waste disposal that have the potential of improving the economics and/or environmental acceptability of recovering ofi from oil shales using the PFH process. The program is divided into the following active* tasks:

- Task 3. Testing of Process Improvement Concepts

- Task 4. Beneficiation Research

- Task 5. Operation of PFH on Beneficiated Shale

- Task 6. Environmental Data and Mitigation Analyses

- Task 7. Sample Procurement, Preparation, and Characterization

- Task 8. Project Management and Reporting.

In order to accomplish all the program objectives, the Institute of Gas Technology (IGT), the prime contractor, is working with four other institutions; the University of Alabama/Mineral Resources Institute (MRI), University of Kentucky Center for Applied Energy Research (UK-CAER) the University of Nevada (UN), and Tennessee Technological University (TTU).

This report presents the work performed during the program quarter from September 1 through November 30, 1991.

* Some of the tasks in the original program were not continued in the current program extension. The task achievements discussed below represent the active tasks of the program. 


\section{ACHIEVEMENTS}

\section{Task 3. Testing of Process Improvement Concepts}

The objective of this task is to obtain data on novel process concepts that have the potential for improving the overall economics of PFH processing with Eastern oil shales. This task is divided into three subtasks corresponding to the concepts being tested: 3.6. Combustion of Hydroretorted Benefi. ciated Shales, 3.7. Innovative Reactor Concept Testing, and 3.8. Niche Market Studies.

\section{Subtask 3,6. Combustion of Hydroretorted Beneficiated Shales}

The overall objective of this subtask is to evaluate the combustion of hydroretorted shale for energy recovery prior to disposal. This subtask is comprised of two subtasks: 3.6.1. Combustion Characterization and 3.6.2. Combustion Tests.

\section{Subtask 3,6.1. Combustion Characterization}

The objective of this subtask is to determine the combustion characteristics of hydroretorted beneficiated shale.

\section{Discussion}

The combustion characteristics of hydroretorted shale will be determined in a series of thermogravimetric tests in an existing high-pressure thermobalance unit. The unit senses and records the instantaneous weight of a sample undergoing reaction at temperatures and pressures up to $982^{\circ} \mathrm{C}$ and $7.0 \mathrm{MPa}$ $\left(1800^{\circ} \mathrm{F}\right.$ and $\left.1000 \mathrm{psig}\right)$.

Thermobalance tests are planned to be conducted as well as determinations of calorific value and elemental composition of the feed and residue samples. The shale will be heated at a low rate to permit determination of the temperature at which combustion is initiated. The effect of pressure on shale combustion characteristics will also be determined.

This task was not active during the quarter. Tests will be initiated next quarter.

\section{Subtask 3,6.2. Fluidized-Bed Combustion Tests}

The objective of this subtask is to demonstrate the combustion of hydroretorted beneficiated shale in a fluidized-bed reactor. Laboratory-scale tests will be conducted at various temperatures, pressures, and shale residence times torevaluate combustion characteristics, attrition, and reactivity. Emissions from the tests will be monitored for environmental purposes as well as for performing overall and elemental material balances. 


\section{Discussion}

Laboratory-scale filuidized-bed combustion tests will be conducted in an existing 5.1 -cm (2-inch) diameter fluidized-bed reactor. Tests will be performed using hydroretorted beneflclated shale generated in Subtask 5.2. The tests will be conducted at pressures of 0.1 and $1.48 \mathrm{MPa}$ (15 and $215 \mathrm{psia}$ ) and combustion temperatures and shale residence times based on the results of subtask 3.6.1.

This task was not active Auring the quarter. Tests will se inftiated next quarter.

\section{Subtask 3.7. Innovat Ive Reactor Concept Iesting}

The objective of this subtask is to demunstrate the lechnical feasibility of generating hydrogen by cracking the by-product hydracaxbon gases on spent shale and combustimg the carbon produced by the cracking reactions. Work is divided into two subtasks: 3.7.1. Cracking Tests and 3.7.2. Oracking Combustion Tests. A laboratory-scale reactor will be deslgned and bullt. for the tests to be conducted in this subtask.

\section{Subtask 3.7.1. Cracking Tests}

The objective of this subtask is to demonstrate the generation of hydrogen by cracking by "product hydrocarbon gases.

\section{Discussion}

During the quarter, IGT completed construction of the crackingcombustion unit. The reactor is $35.6 \mathrm{~mm}$ (1.4 inch) in internal diameter (ID) by $61 \mathrm{~cm}(24 \mathrm{Inch})$ long and is capable of operating up to $1204^{\circ} \mathrm{C}$ and $7.0 \mathrm{MPa}$ $\left(2200^{\circ} \mathrm{F}\right.$ and $\left.1000 \mathrm{ps} 1 \mathrm{~g}\right)$. Anclllary equipment fncludes pressure and temperature controllers and indicators, gas feed and sampling systems, and a data logging recorder. All system components, except the raactor, are constructed from 316 stainless steel. The reactor is constructed from 309 stainless steel, which has better high-temperature properties.

The panel board was constructed and the process instrumentation was mounted. The instrumentation, tubing, electrical supply, and wiring were installed. Electrical connections needed for the furnace, furnace control. lexs, and relays were made. The tubing and wiring connections, thermocouple placement, furnace and reactor installation, instrumcnt calihration, and pressure testing were completed. Shakedown testing of the unit will begin next quarter.

\section{Subtask $3,7,2$ Cracking-Combustion Tests}

The objective of this subtask is to demonstrate the combustion of carbon produced by the cracking of hydrocarbon gases. 


\section{Discussion}

The same test unit constructed for the cracking tests in Subtask 3.7.1 w111 be used for the cracking-combustion tests. In the tests planned for this subtask, carbon will be deposited on hydroretorted beneflclated shale at condit..ons determined in Subtask 3.7.1. A combustion cycle will then be performed on each sample to determine the conditions for removing the deposited carbon by combustion. One of the tests will consist of multiple crackingcombustion cycles and w11l be conducted to determine the effects of recycling on the shale and its reactivity.

No cracking-combustion tests were performed this quarter. These tests wil be conducted after completion of the cracking tests in subtask 3.7.1.

\section{Subtask 3.8. Niche Market Studies}

The objective of this subtask is to determine the potential for producing hydroretorted shale ofl co-products, such as asphalt additives. Tests will be performed to characterize hydroretorted shale oil asphalts and pavements containing these sphalts.

\section{Discussion}

Niche market studies will focus on the production and characterization of asphalt additives produced by the PFH processing of beneficlated Eastern oil shale. A series of screening tests will be conducted in an existing batch PFH unft to find the hydroretorting conditions for producing the highest yield of asphalt additive. An asphaltic fraction to be used as an additive will be separated from the product oll generated in Subtask 5.2. This asphalt additive and briquette samples cuntaining this asphalt, will be characterized by standard methods including viscosity, penetration, ductility, thin-film oven testing, and water susceptibility. The characteristics of the asphalt with the shale ofl additive will be compared with the properties of a typical petroleum asphalt.

During the quaxter all of the equipment, including viscometer and hightemperature bath, laboratory oven, and penetrometer were recelved. The base plates for the water susceptibility tests were prepared. The bulk sample of pelletizad, beneficlated shale was delivered to IGT and a representative sample was collected for use in the asphalt screening tests.

Asphalt screening tests will begin next quarter.

\section{Task 4. Beneficiation Research}

The objective of this task is to test several novel and advanced grinding and beneficiation concepts, which have shown promising results with roal, for processing Eastern shales. This task is divided into four subtasks: 4.1. Grinding Studies (Subtask 4.1.4. Grinding Circuit Design), 4.4. Integrated Grinding and Flotation, 4.5. Evaluation of Different Grinding Media, and 4.6. Evaluation of Concentrate Preparation Techniques (Subtasks 4.6.1. Of.1 Agglomeration and Pelletizing and 4.6.2. Bioflocculation of Kerogen). 


\section{Discussion}

The overall responsibility for this task is assumed by the Mineral Resources Institute (MRI) of the University of Alabama. One of the subtasks (4.4) is being conducted by the University of Kentucky Center for Applied Energy Research (UK-CAER), as a subcontractor to MRI. Subtask (4.6.2) is being conducted by the University of Nevada, Reno (UN), also as a subcontractor to MRI. The achievements made during the quarter are described below.

\section{Subtask 4,1. Grinding Studies}

\section{Subtask 4.1.4. Grinding-Flotation Circuit Design}

During the quarter, MRI continued work on determining methods for reducing stirred ball mill grinding costs. Because of the high capital and operating costs of stirred ball milling, the focus of this work was on re. moving material already ground to flotation size from the feedstock to minimize the quantity of material that must be ball milled. MRI assumed that a coarse grinding circuit would produce stirred ball mill feedstock in the size ranges of elther $-100,-200$, or -460 mesh and prepared quantities of these feed consists for testing.

To obtain these feedstocks, MRI ground several hundred pounds of Alabama shale to -100 mesh in a continuous $0.9 \times 1.37 \mathrm{~m}(3 \times 1.5 \mathrm{ft})$ ball mill at 50 weight percent solids. Hydrocycloning tests were then conducted on the -100 mesh sample using a $5.1-\mathrm{cm}(2-1 \mathrm{nch})$ cyclone. When these tests were completed, the separated samples were combined and reconstituted, and then wet screened to -200 mesh to separate that fraction for the stirred ball mill feed. After hydrocyclone test.s were completed on the -200 mesh feedstock, the separated. samples were again combined and reconstituted, and then wet screened to -460 mesh to represent a finely ground stixred ball mill feedstock. The particle size distributions of these feedstocks are shown in Table 4-1.

Table 4-1 shows that a coarse-grinding circuit producing a -200 mesh discharge, rather than a -100 mesh discharge, would require about 20 percent additional primary grinding capacity. Similarly, a coarse grinding circuit with a -460 mesh discharge would require about 38 percent additional primary grinding capacity compared to that with a -100 mesh discharge. MRI will determine the additional capital and operating costs required to produce a coarse grinding circuit discharge of -200 and -460 mesh for comparison with those required to produce a -100 -mesh discharge. MRI will also determine the effect of reducing the top size of the feed on the operating costs of stirred ball milling.

Hydrocyclone Tests. MRI conducted hydrocyclone tests on each of the three coarse grinding circult discharges mentioned above (Table 4-1) to reduce the quantity of shale reporting as stirred ball mill feed. In each case, the $d_{x}$ of the cyclone overflow and the quantity of the cyclone overflow were determined to evaluate the affect of cyclone feed rolids and cyclone feed pres. sure. It is desirable to remove the maximum amount of flotation-size material in the hydrocyclone overflow product, while producing a cyclone underflow pro- 
duct sufficiently high in solids ( 4 5 to 55 percent) to go directly to stirred ball milling without subsequent thiskening. Figure 4-1 shows the results of

Table 4-1. SIZE CONSIST OF COARSE-GRINDING CIRCUIT DISCHARGES (Stirred Ball Mill Feed)

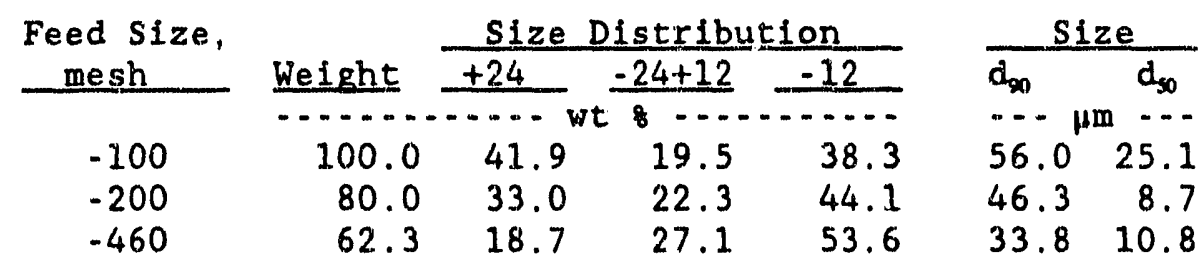

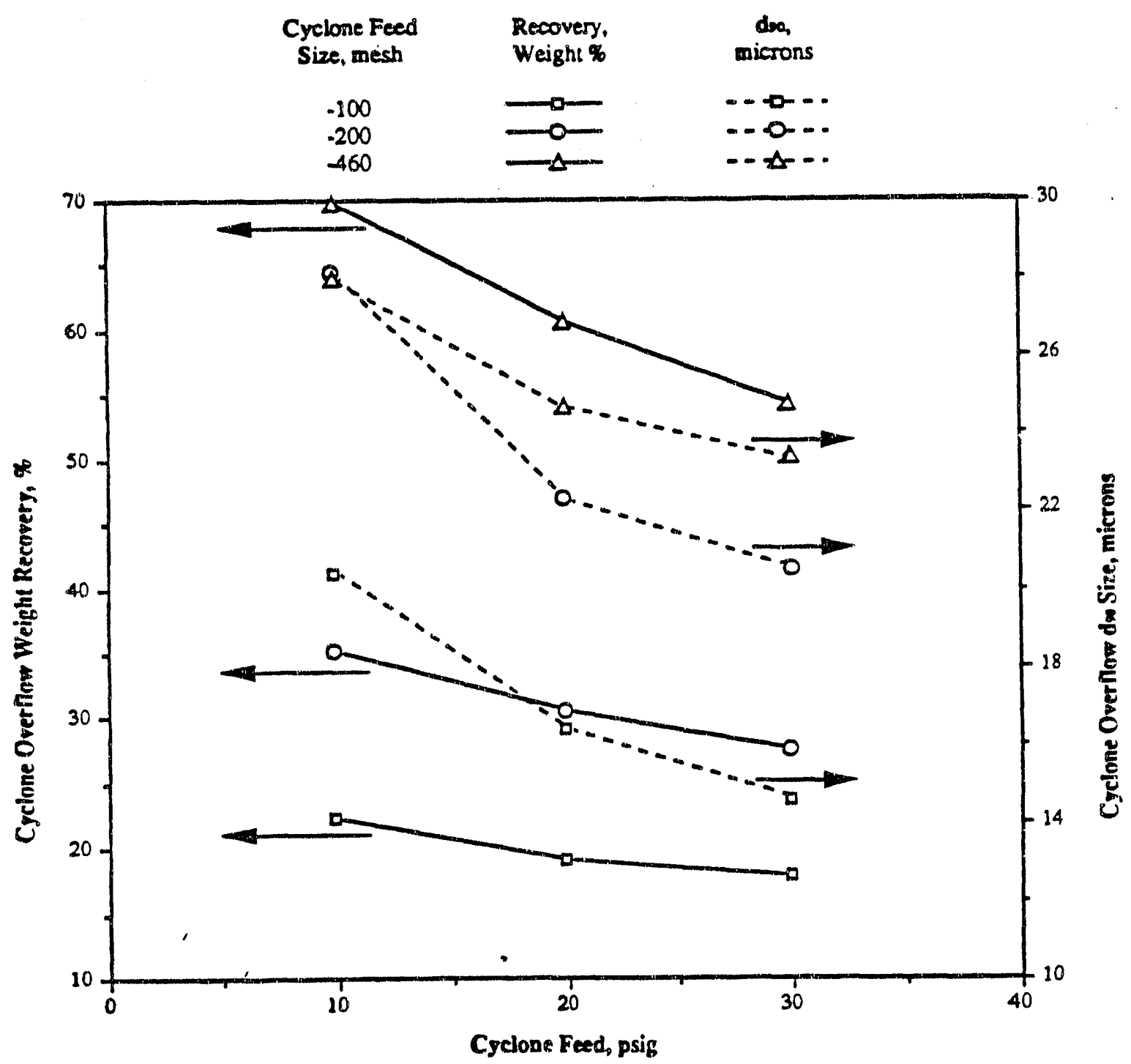

Figure 4-1. EFFECT OF CXCLONE PRESSURE AND FEED SIZE AT HIGH FEED SOLIDS ( 27 to 31 Percent) 
hydrocycloning tests with the three feedstocks at high solids (27 to 31 percent) which, in all cises, gave cyclone underflows in the range desired for stirred ball mill feedstock; however, none of the conditions investigated gave cyclone overflows in the $d_{x 0}$ range required for flotation feed; $1 . e, 10$ micrometers $(\mu \mathrm{m})$. The lowest $d_{x p}$ obtained in these high solids cyclone feed studies was $14.6 \mu \mathrm{m}$ at a weight recovery of 18 percent.

Other hydrocyclone tests conducted on the three feedstocks at feed solids concentrations in the ranges of 12 to 15 and 5 to 7 percent yielded the results shown in Figures 4-2 and 4-3. The results show that the $d_{\infty}$ of the cyclone overflow product can be in the 11 to $12 \mu \mathrm{m}$ range, thus reducing the quantity of material reporting as stirred ball mill feedstock. However, the cyclone underflow products produced in the lower cyclone feed solids ranges would require thickening to yield stirred ball mill feedstock in the 45 to 50 percent solids range required. The data indicate that as feed size decreases, weight recovery of the cyclone overflow increases at a constant $d_{90}$.

Hydrocyclone studies were conducted to determine if re-treating a primary cyclone underflow prcduct one or two additional times would significantly increase the recovery of flotation-sized material. The results (Table 4-2) show that the hydrocyclone is relatively inefficient in recovering the $-12 \mu \mathrm{m}$ fraction of the cyclone feed. Re-treatment of the cyclone underflow two times yielded a 52 percent recovery of the $-12 \mu \mathrm{m}$ fraction in the cyclone feed at a $d_{90}$ of $14.5 \mu \mathrm{m}$.

MRI also conducted hydrocyclone tests on a sample of low-grade flotation concentrate (22.28 carbon and 9.68 sulfur with a $d_{x}$ of $27 \mu \mathrm{m}$ ) in a $5.1-\mathrm{cm}$ cyclone to determine if there was a significant difference in the cyclone overflow and underflow products. The cyclone feed pressure was held constant at $239 \mathrm{kPa}$ ( $20 \mathrm{psig}$ ) and the feed solids were varied from 25 to 5.8 percent solids. The results (Table 4-3) show that the solids content of the cyclone feed had only a small effect on the carbon grade in the cyclone overflow product; however, there was a reduction in the sulfur content of cyclone overflow product.

Since the presence of sulfur increases hydrogen consumption in the PFH process, additional hydrocyclone studies were made of this low-grade concentrate to determine the effect of increased cyclone feed pressure on the sulfur content of the cyclone overflow product. In these studies, a Dorr-01iver cluster cyclone, containing four $10-\mathrm{mm}$ cyclones, was used to obtain pressures as high as $584 \mathrm{kPa}$ ( $70 \mathrm{psig}$ ). The solids content of the cyclone feed was held constant at 6.1 percent. The results of these tests (Tables 4-3 and 4-4) indicate that low weight reccveries and only small increases in carbon content can be expected when cycloning a low-grade concentrate. The results also indicate the potential for reducing pyritic sulfur in higher grades of concentrate by cycloning.

Grinding Circuit Tests. MRI established a continuous grinding and sizing circuit to produce sufficient material for future grinding and column cell flotation studies. The circuit (Figure 4-4) was initially operated at a shale feed rate of $0.9 \mathrm{~kg}$ per hour $(2 \mathrm{lb} / \mathrm{h})$ at 50 percent solids. After circuit shakedown, the plant operated about one hour before electrical problems 


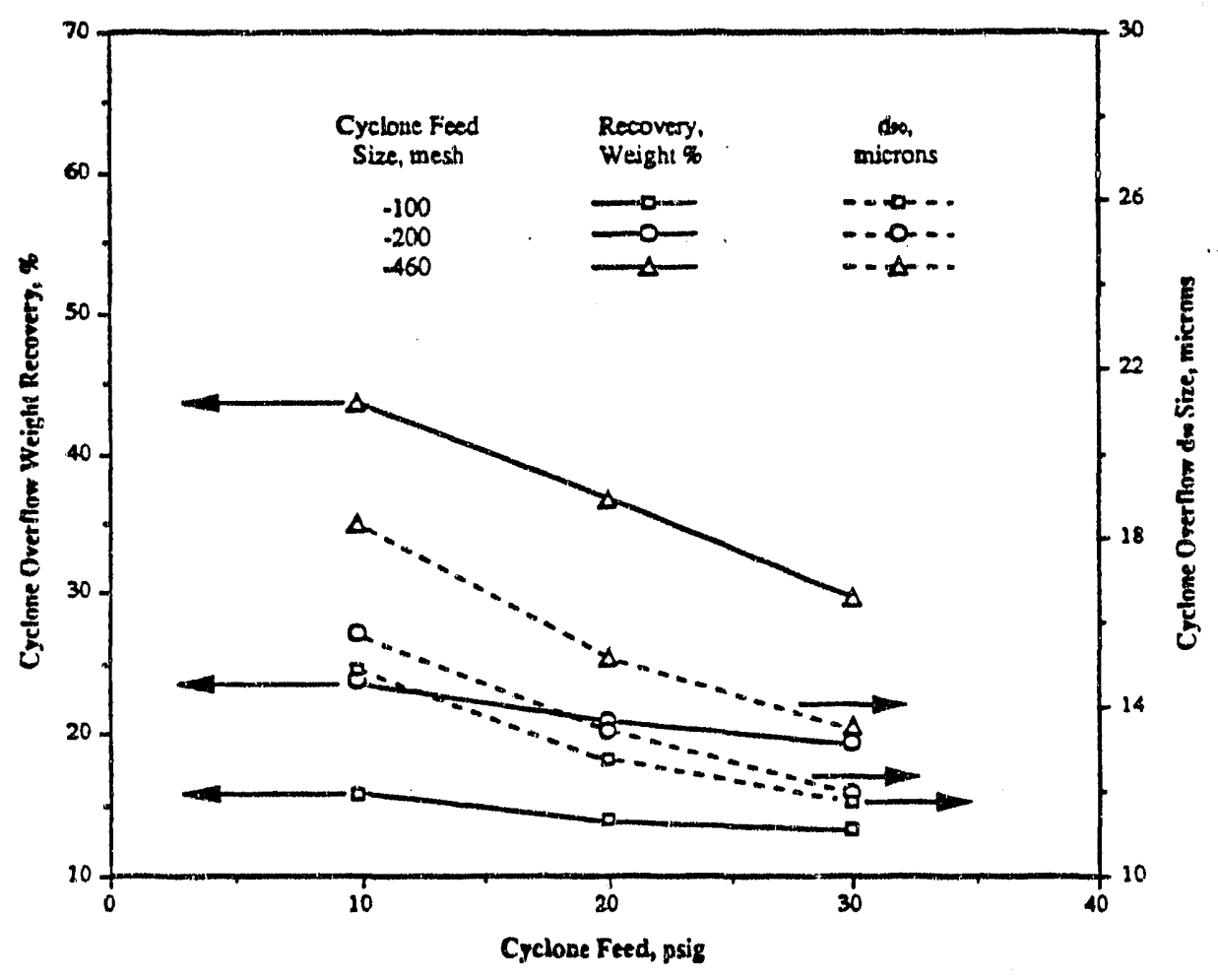

Figure 4-2. EFFECT OF CYCLONE PRESSURE AND FEED SI7E AT MEDIUM FEED SOLIDS ( 12.5 to 15 Percent)

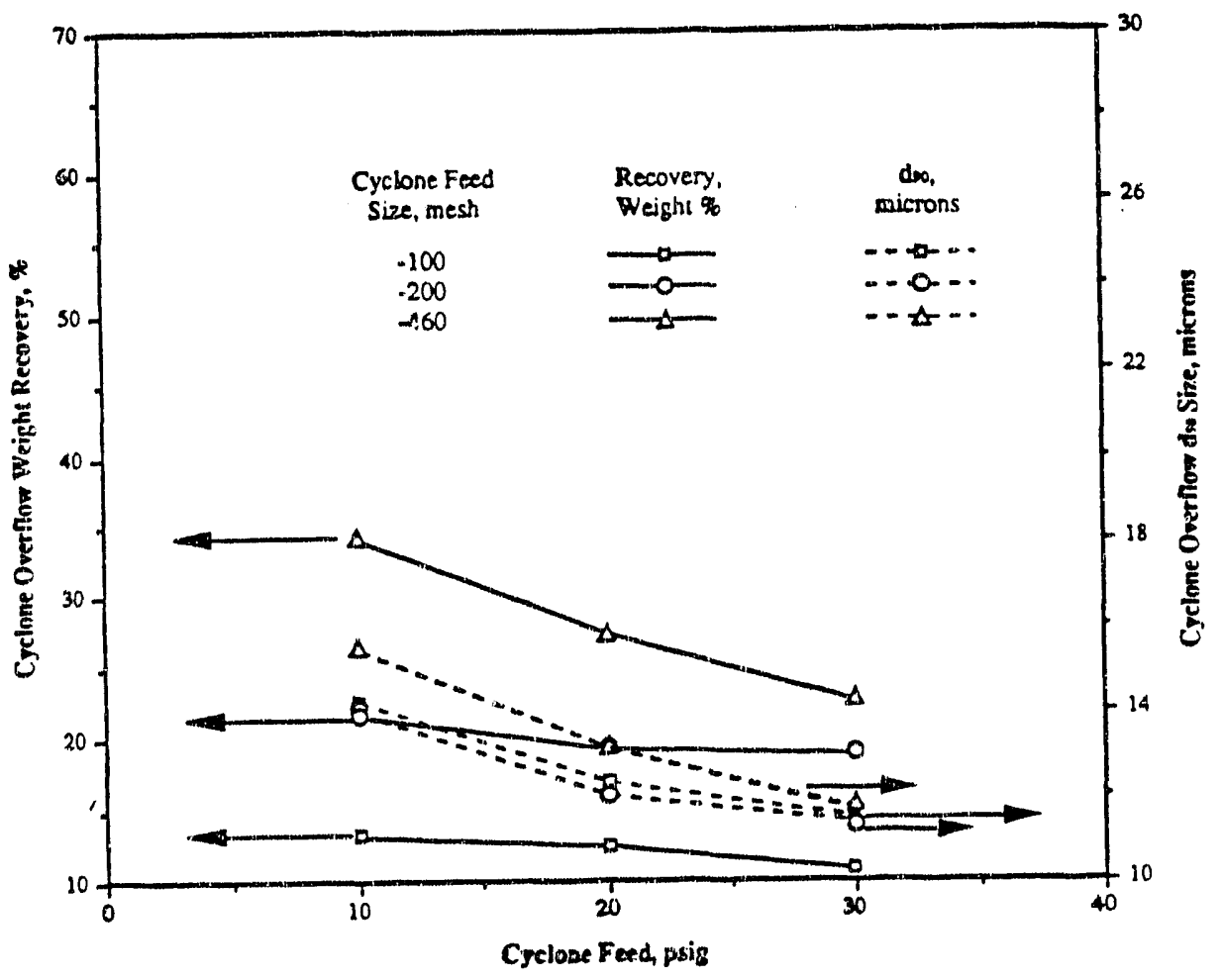

Figure 4-3. EFFECT OF CYCLONE PRESSURE AND FEED SIZE AT LOW FEED SOLIDS ( 4.8 to 6.8 Percent) 
Table 4-2. TYCLONING - 100 MESH ALABAMA SHALE AND RECLEANING THE CYCLONE UNDERFLOW PRODUCT

\begin{tabular}{|c|c|c|c|c|c|c|c|c|c|c|c|c|}
\hline \multirow{3}{*}{$\begin{array}{l}\text { Product } \\
\text { Cyclone } \\
\text { Overflow }\end{array}$} & \multirow{3}{*}{$\begin{array}{c}\text { Pass } \\
\\
9 \\
2 \\
3\end{array}$} & \multirow{2}{*}{$\begin{array}{l}\text { Pressure } \\
\text { psin }\end{array}$} & \multirow{2}{*}{$\begin{array}{l}\text { Feed } \\
\text { solids }\end{array}$} & \multirow{2}{*}{ Veight } & \multicolumn{3}{|l|}{ si } & \multicolumn{3}{|c|}{ Distribution } & \multicolumn{2}{|c|}{ size } \\
\hline & & & & & 424 & $\mathrm{sen}$ & -12 & +24 & ..... & -12 & $d_{\infty}$ & $d_{60}$ \\
\hline & & $\begin{array}{l}20 \\
30 \\
30\end{array}$ & $\begin{array}{l}13.7 \\
10.0 \\
10.0\end{array}$ & $\begin{array}{r}13.2 \\
7.2 \\
3.1 \\
\end{array}$ & $\begin{array}{l}0.4 \\
2.0 \\
4.8\end{array}$ & $\begin{array}{l}10.9 \\
13.8 \\
19.9\end{array}$ & $\begin{array}{l}88.0 \\
84.3 \\
74.6\end{array}$ & $\begin{array}{l}\text { Tr } \\
0.3 \\
0.4\end{array}$ & $\begin{array}{l}7.4 \\
5.9 \\
3.2 \\
\end{array}$ & $\begin{array}{r}30.4 \\
16.9 \\
6.1 \\
\end{array}$ & $\begin{array}{l}13.0 \\
14.9 \\
19.8\end{array}$ & $\begin{array}{l}4.7 \\
5.1 \\
6.8\end{array}$ \\
\hline Overflow & $1-3$ & $\cdots$ & $\cdots$ & 23.6 & 1.5 & 13.0 & 85.1 & 0.8 & 15.7 & 52.6 & 14.5 & 5.1 \\
\hline Underf low & 3 & 30 & $\cdots$ & 76.4 & 53.7 & 21.5 & 23.7 & 99,2 & 84.3 & 67.4 & 94.3 & 22.2 \\
\hline Feend $(-10)$ & mesh & & & 100.0 & 49.4 & 19.5 & 38.2 & 100.0 & 100.0 & 100.0 & 75.5 & 18.2 \\
\hline
\end{tabular}

Trace.

Table 4-3. EFFECT OF CYCLONE FEED SOLIDS AT 20 psig

Feed Sample Analysis, Fraction of Element

\begin{tabular}{l} 
Solids, Cyclone Overflow \\
wt 8 Recovery, wt 8 Carbon 8 in Overflow, wt o \\
\hline
\end{tabular}

$\begin{array}{rrrrrr}25 & 39.2 & 27.8 & 7.24 & 49.1 & 29.6 \\ 12.9 & 29.1 & 28.5 & 6.65 & 37.3 & 20.2 \\ 5.8 & 25.1 & 28.6 & 6.22 & 32.8 & 16.6\end{array}$

Table 4-4. EFFECT OF CYCLONE FEED PRESSURE AT 6.18 FEED SOLIDS Feed

Pressure, Cyclone Overflow Analysis, wt \& Distribution, wt 8 psig Recovery, wt 8 Carbon Sulfur Carbon sulfur

$\begin{array}{llllll}30 & 15.1 & 28.9 & 5.39 & 19.7 & 8.5 \\ 50 & 13.9 & 29.4 & 5.24 & 18.3 & 7.8 \\ 70 & 12.7 & 29.5 & 5.13 & 16.9 & 6.8\end{array}$


forced a shutdown. The particle size analysis of the hydrocyclone overflow product produced prior to shutdown gave a $d_{0}$ of $15.1 \mu \mathrm{mi}$. The particle size analysis of the Derrick screen undersize showed a $d_{\infty}$ of $29 \mu \mathrm{m}$. Because of the short running time, no effort was made to balance the weight recoveries of the individual products.

The electrical problem in the grinding and sizing circuit has been isolated and repaired, the operation will be resumed next quarter. Several hundred kilograms of shale will be ground in the circuit to produce feedstock for column cell flotation and stirred ball mill studies.

\section{Subtask 4.4. Integrated Grinding and Flotation}

The objectives of this subtask are to determine the column flotation characteristics of Eastern shale and to investigate the application of a novel integrated grinding and column flotation technique in a single-stage operation. The University of Kentucky Center for Applied Energy Research (UK-CAER) is evaluating the advanced Ken-Flote column flotation technique in conjunction with the BDR. Mill column to obtain a high grade $(125.2 \mathrm{~L} /$ metric ton; $>30$ gallons per ton (GPT]) oil shale at more than 90 percent carbon recovery. The BDR Mill column utilizes a single-stage grinding/cleaning system that avoids overgrinding the shale. The goals of the project are to remove up to 90 percent of the inorganic minerals using minirum grinding energy.

During the quarter, UK-CAER conducted column flotation tests in the 5.1$\mathrm{cm}(2-$ inch) diameter $6.1 \mathrm{-m}$ high $(20-\mathrm{ft})$ Ken-Flote column. Betz M252 was used as a frother. The effects of wash water addition rate and froth height on grade and recovery of organic carbon was evaluated. The wash water addition rate was varied from 0.2 to $0.6 \mathrm{~L} / \mathrm{min}$, while the air flow, feed rate, and froth height were maintained at $3 \mathrm{~L} / \mathrm{min}, 1 \mathrm{~L} / \mathrm{min}$, and $1.2 \mathrm{~m}$ ( 4 feet), respectively. The highest organic carbon recovery achieved was 56 percent at a grade of 61.8 percent with a wash water rate of $0.4 \mathrm{~L} / \mathrm{min}$.

Froth height was varied from 0.6 to $1.8 \mathrm{~m}$ (2 to 6 feet) and the optiun was determined to be $1.2 \mathrm{~m}$ (4 feet). A few tests were also conducted to study the effect of dispersant (sodium hexametaphosphate) addition. At up to 2.5 $\mathrm{kg} /$ metric ton ( $5 \mathrm{lb} / \mathrm{ton}$ ) addition, the dispersant did not improve grade or recovery of organic carbon.

UK-CAER also conducted some tests with pine oll added to the slurry at $0.45,0.67$, and $0.90 \mathrm{~kg} /$ metric ton $(1,1.5$, and $2.01 \mathrm{~b} /$ ton of shale). The flow rate of air to the column was varied between 2 and 3 liter/minute ( 4.2 to $\left.6.41 \mathrm{ft}^{3} / \mathrm{h}\right)$. The results showed that at an air flow rate of $3 \mathrm{~L} / \mathrm{min}$ and a pine oil addition of $0.90 \mathrm{~kg} /$ metric ton, a recovery of 73 percent was achieved. The concentrate from this test contained 43 percent organic carbon. Reducing the air flow rate to $2 \mathrm{~L} / \mathrm{min}$, resulted in a concentrate with 52.5 percent organic carbon and a recovery of 65 percent. 


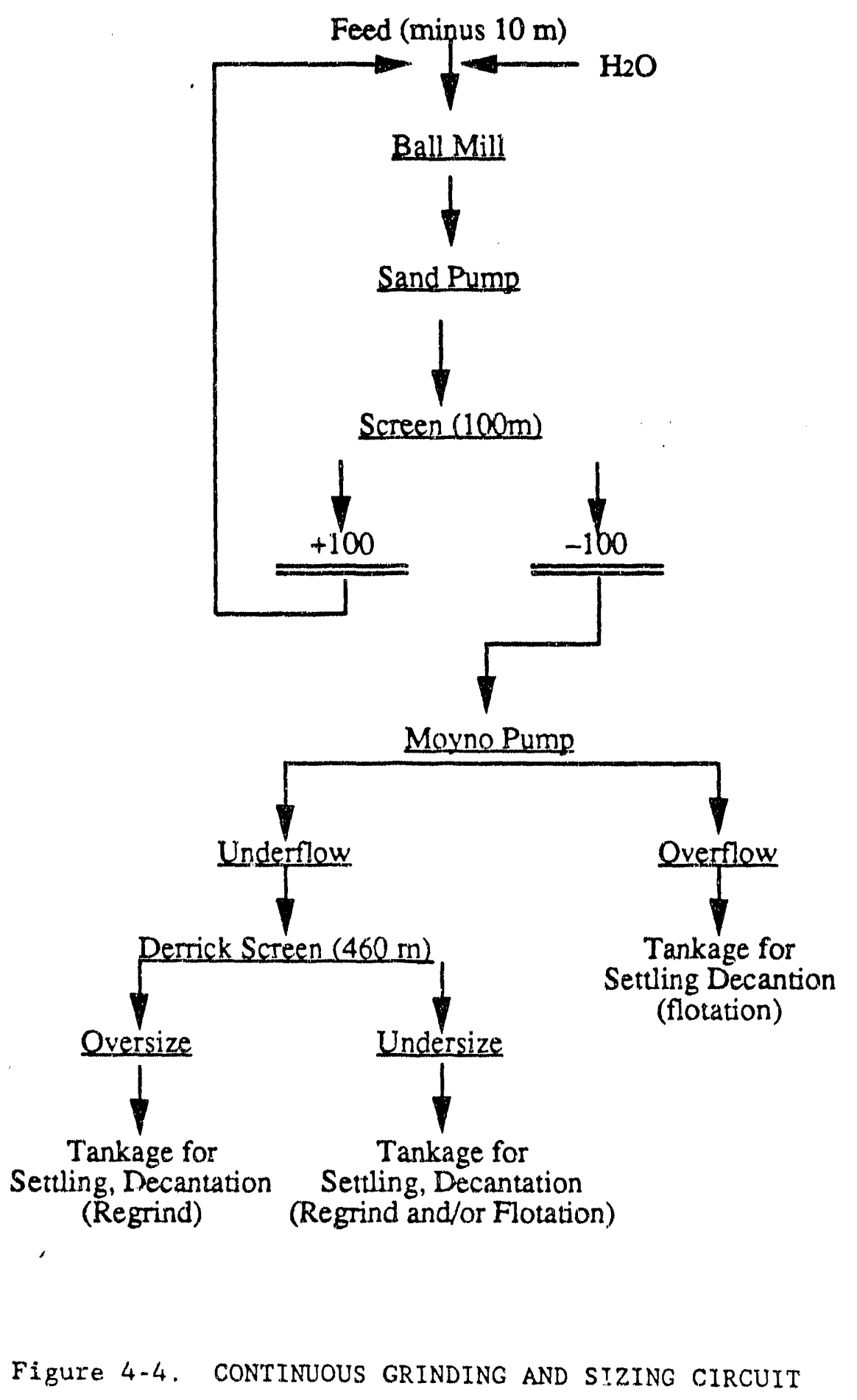


The effect of adding fuel oll to the feed slurry was also determined. The results showed that with a constant pine oil addition of $0.67 \mathrm{~kg} / \mathrm{metric}$ ton, increasing the fuel o11 concentration from 0.67 to $2.2 \mathrm{~kg} / \mathrm{metric}$ ton, tecreased the organic carbon content of the product from 47 to 42 percent.

The effect of slurry feed rate was also determined. For these tests, the column operating conditions were kept constant at $2 \mathrm{~L} / \mathrm{min}$ aix flow rate, $0.4 \mathrm{~L} / \mathrm{min}$ wash water, and $0.67 \mathrm{~kg} /$ metric ton pine oil. As the feed rate was reduced from 1 to $0.5 \mathrm{~L} / \mathrm{min}$, the recovery increased from 50.9 to 59.9 percent; however, the grade of the organic carbon content of the concentrate decreased from 47.4 to 39.7 percent.

In another series of tests, UK-CAER obtained a rougher concentrate in the first stage and floated again in a cleaner stage to improve the grade of the column flotation froth product. In the rougher stage, the recovery of carbon was 54.7 percent with a concentrate grade of 47.8 percent carbon. Cleaner flotation of this product yielded 54.8 percent carbon recovery with a concentrate grade of 50.8 percent carbon. The overall recovery for this twostage process was 30.0 percent with a final grade of 56.8 percent carbon. These results show that a cleaner flotation can increase the carbon content of the final froduct, however, the overall recovery is poor. This test was conducted using the static sparger for fine bubble generation with a concentration of $1 \mathrm{~kg}$ of pine oil per metric ton of shale. To improve the overall recovery it would be necessary to significantly increase the recovery in the rougher flotation stage.

Additional column flotation tests were conducted using the foam jet bubbie generating device. Increasing the pine oil concentration from 1 to 5 $\mathrm{kg} /$ metric ton increased carbon recovery from 36.8 to 56.0 percent, while decreasing the concentrate grade from 45.4 to 33.8 percent carbon. Varying the concentration of fuel oil from 0.5 to $2.5 \mathrm{~kg} /$ metric ton (M252 frother added at $0.75 \mathrm{~kg} /$ metric ton) improved the recovery from 42.8 to 95.8 percent. However, the concentrate grade decreased from 40.7 to 18.2 percent carbon over the same concentration range. These results show that for single-stage flotation, fuel oil and M252 frother provide significantly higher recovery than pine oil when the foam jet is used for bubble generation. However, the grade of the concentrate obtained with pine oil is much higher than that obtained with fuel oil and $M 252$.

Next quarter, UK-CAER will conduct additional tests in the Ken-Flote column with the foam jet bubble generating system. Their work will focus on the addition of wash water and on cleaning with a cleaner flotation stage to improve the concentrate grade without sacrificing recovery.

\section{Subtask 4.5. Evaluation of: Different Grinding Media}

The components of stirred ball milling costs are power, media consumption, and capital (installed equipment). Previous studies by MRI have focused on minimization of power consumption in a stirred ball mill using steel media (2-mm and 1.1-mm diameter balls) and the John Option stirring device. These studies have shown that smaller grinding media is more efficient in producing $-10 \mu \mathrm{m}$ product. However, the cost of $1.1-\mathrm{mm}$ steel media is substantially 
higher than that of the 2-mm media. Thus, the power savings are offset by the higher media consumption costs.

In order to compare grinding efficiency of steel and sand media, a single, large batch of Alabama shale rougher concentrate having a $d_{90}$ of 27.3 and $d_{50}$ of $10.3 \mu \mathrm{m}$ at 41 percent solids was used in all grinding experiments. The John Option was tested with sand and steel media; the Molinex Option was tested with sand only. Equal size of steel and sand media $(1.1 \mathrm{~mm}$ ) at 85 percent loading was used. The grinding data was collected by varying feed rates and rotor speed. Subsequently, modified Charles size reduction energy relationships were developed as follows:

$$
\begin{array}{ll}
E-2.3157 \times 10^{4} \times d_{50, p}^{(-3.2790)} & \text { Molinex-Sand media } \\
E-1.0708 \times 10^{5} \times d_{50, p}^{(-.2253)} & \text { John-Sand media } \\
E-6.2950 \times 10^{5} \times d_{50, p}^{(-5.2549)} & \text { John-Steel media }
\end{array}
$$

An energy efficiency evaluation of these mill media combination can be done by simulation. The simulated values of ( $E$ versus $d_{50}$ ) are shown in Table 4-5. The data show that for ultra-fine grinding to a $d_{s 0}$ of $6 \mu \mathrm{m}$ or less, sand media requires less energy than steel media. For a smaller size reduction ratio, in which the product $d_{s 0}$ is between 6 and $9 \mu \mathrm{m}$, steel media requires less energy.

Table 4-5. PREDICTION OF GRINDING ENERGY REQUIRED BASED ON MODIFIED CHARLES RELATIONSHIPS FOR VARIOUS MEDIA

\begin{tabular}{|c|c|c|}
\hline \multicolumn{2}{|c|}{ 1.1- $\mathrm{mm}$ Sand } & $1.1-\mathrm{mm}$ steel \\
\hline John Opt. & Molinex Opt. & John Option \\
\hline$\ldots \ldots \ldots$ & $\cdots E(\mathrm{kWh} / \mathrm{t})$ & $\ldots \ldots \ldots$ \\
\hline 966.2 & 630.8 & 1935.4 \\
\hline 281.8 & 245.6 & 425.5 \\
\hline 108.2 & 118.1 & 131.4 \\
\hline 49.6 & 65.0 & 50.3 \\
\hline 25.6 & 39.2 & 22.3 \\
\hline 14.4 & 25.3 & 11.1 \\
\hline 8.7 & 17.2 & 6.0 \\
\hline 5.6 & 1.2 .2 & 3.4 \\
\hline
\end{tabular}
COMBINATIONS WITH ALABAMA SHALE ROUGHER CONCENTRATE

Product Median
Size, d d $_{5, p+\ldots m}$
3
4
5
6
7
8
9
10

It is also of interest to see whether the characteristic shape of the product shale distribution produced is different for steel and sand media. A reasonable way to compare this will be at equal vaiues of product $d_{50}$. Table 4-6 lists the product $d_{s 0}$ obtained in sand and steel media runs. A meaningful comparison of the effect of medie will be had by comparing sample 5 with sample 13 and sample 7 with sample 11. A strict comparison on the effect of mill type cannot be made; however, a close approximation can be made by comparing sample 2. with sample 4 and 8 . These comparisons are shown in Figures 4-5 through 4-7. The shape of the size distribution is similar for both media and mill comparisons. 
Table 4-6. PRODUCT $d_{30}$ VALUES FOR MILL-MEDIA SYSTEM

$\begin{array}{ccc}\begin{array}{c}\text { Mill-Media } \\ \text { Combination }\end{array} & \text { Sample No. } & \text { Product } d \\ \text { Molinex-Sand } & 1 & \\ & 2 & 5.8 \\ & 3 & 5.0 \\ \text { John-Sand } & 4 & 5.4 \\ & 5 & 5.1 \\ & 6 & 4.8 \\ & 7 & 4.3 \\ & 8 & 4.7 \\ \text { John-Steel } & & 4.9 \\ & 9 & 4.6 \\ & 10 & 5.0 \\ & 11 & 4.7 \\ & 12 & 4.2 \\ & 13 & 4.8\end{array}$

\section{Subtask 4.6 Evaluation of Concentrate Preparation Techniques}

Subtask 4.6.1 Oil Agglomeration and Pelletizing

Beneficiation of Eastern shales by column flotation results in a product of superior chemical composition (ie., $-40 \mathrm{GPT}$ ), which requires further processing. The concentrate is obtained as a dilute ( $>95$ percent water) slurry of fine kerogen $\left(d_{x_{0}}>10 \mu \mathrm{m}\right)$. A potential treatment scheme would consist of thickening, pressure filtxation, briquetting, and thermal drying.

The objective of this task is to investigate other techniques that have the potential to reduce the cost of preparing concentrate for the PFH process, such as oil agglomeration. The potential advantages of oil agglomeration are that filtration is not required and, because the agglomerating oil tends to fill the interstices between kerogen grains, only surface moisture must be removed by thermal drying.

MRI produced batches of agglomerates by the method illustrated in Figure 4-8 (Flowsheet 1). While this sequence of process steps is satisfactory for laboratory-scale application, it would not likely be the sequence selected for large-scale production. Three alternative process flowsheets, also shown in Figure 4-8, have been selected for study in this program. Flowsheets 2 and 3 are oil agglomeration techniques and Flowsheet 4 is a standard pelletizing approach. MRI, has focused their efforts on the conditioning step which appears in all three phases. Samples of concentrate slurry, thickened to about 25 percent solids, were conditioned for 1 minute in a high speed blender with additions of 5 percent asphalt. The asphalt was added as a fatty acidstabilized emulsion. After conditioning, the sample showed substantial air entrainment but no discernible phase separation. Further, microscopic examination revealed no agglomeration or flocculation. Filtration tests 


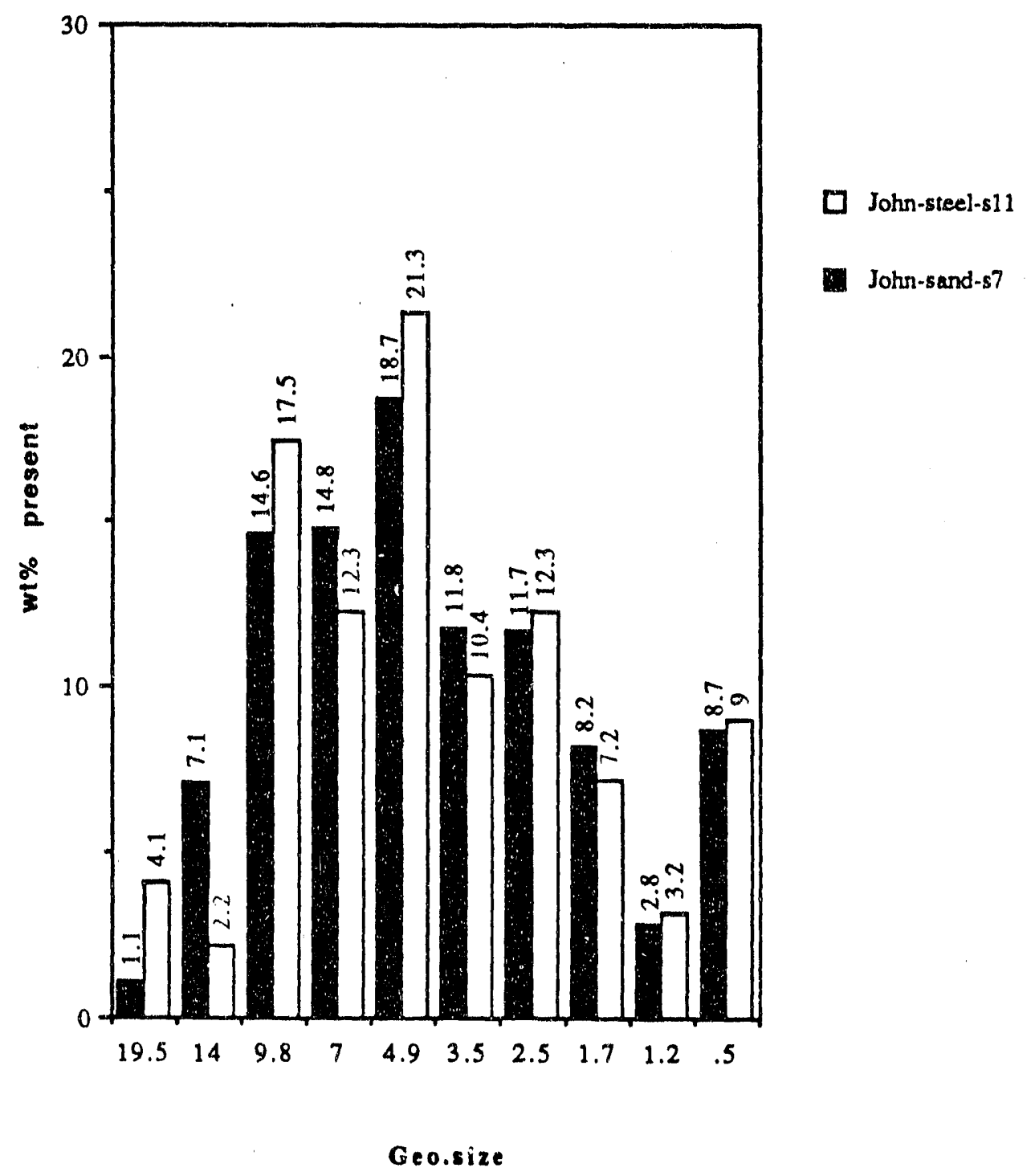

Figure 4-5. EFFECT OF MEDIA TYPE ON THE SHAPE OF PARTICLE SIZE DISTRIBUTION AT SIMILAR PRODUCT MEDIAN SIZE 


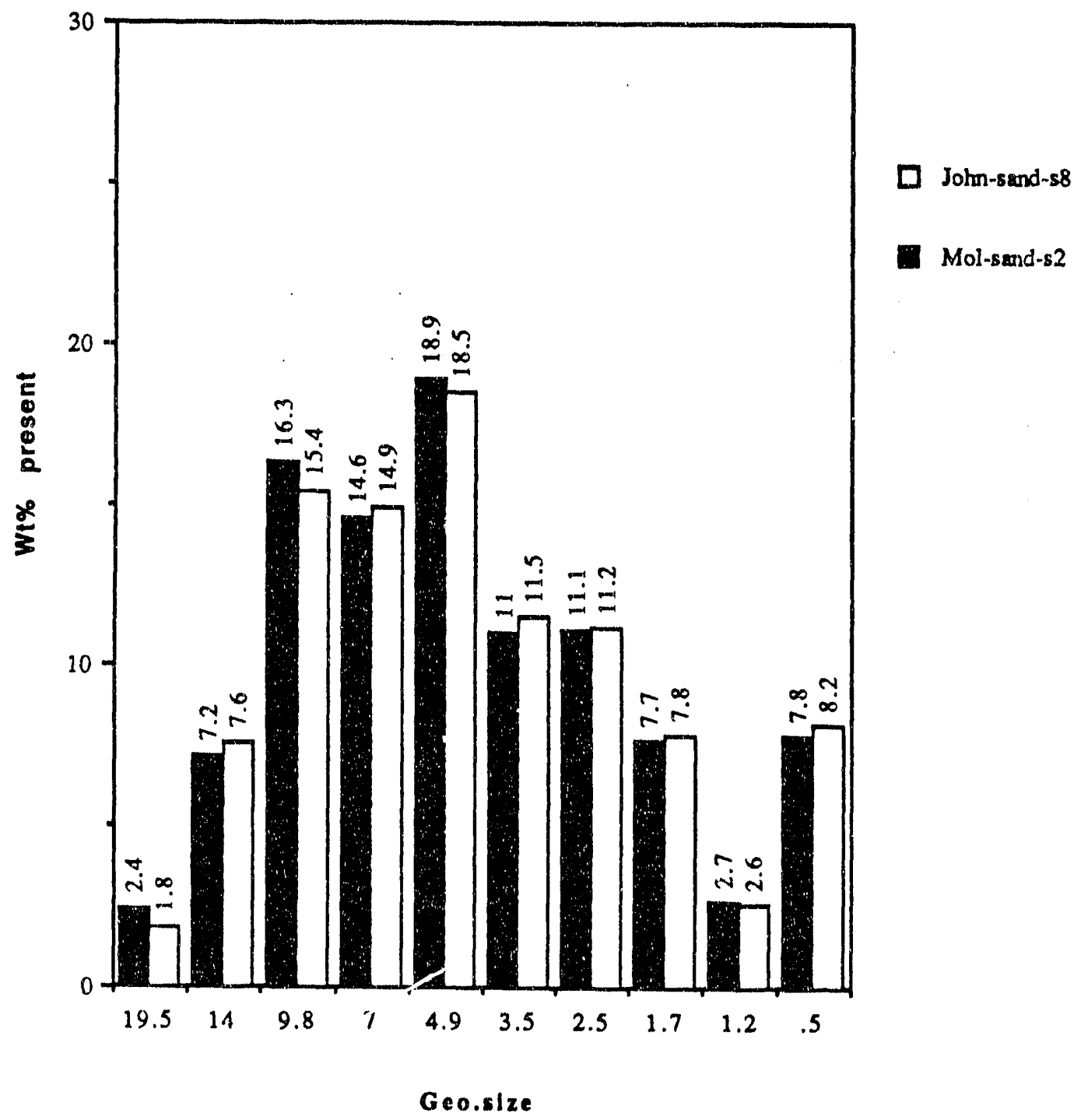

Figure 4-6. EFFECT CF MILL TYPE ON THE SHAPE OF PARTICLE SIZE DISTRIBUTION AT SIMILAR PRODUCT MEDIAN SIZE 


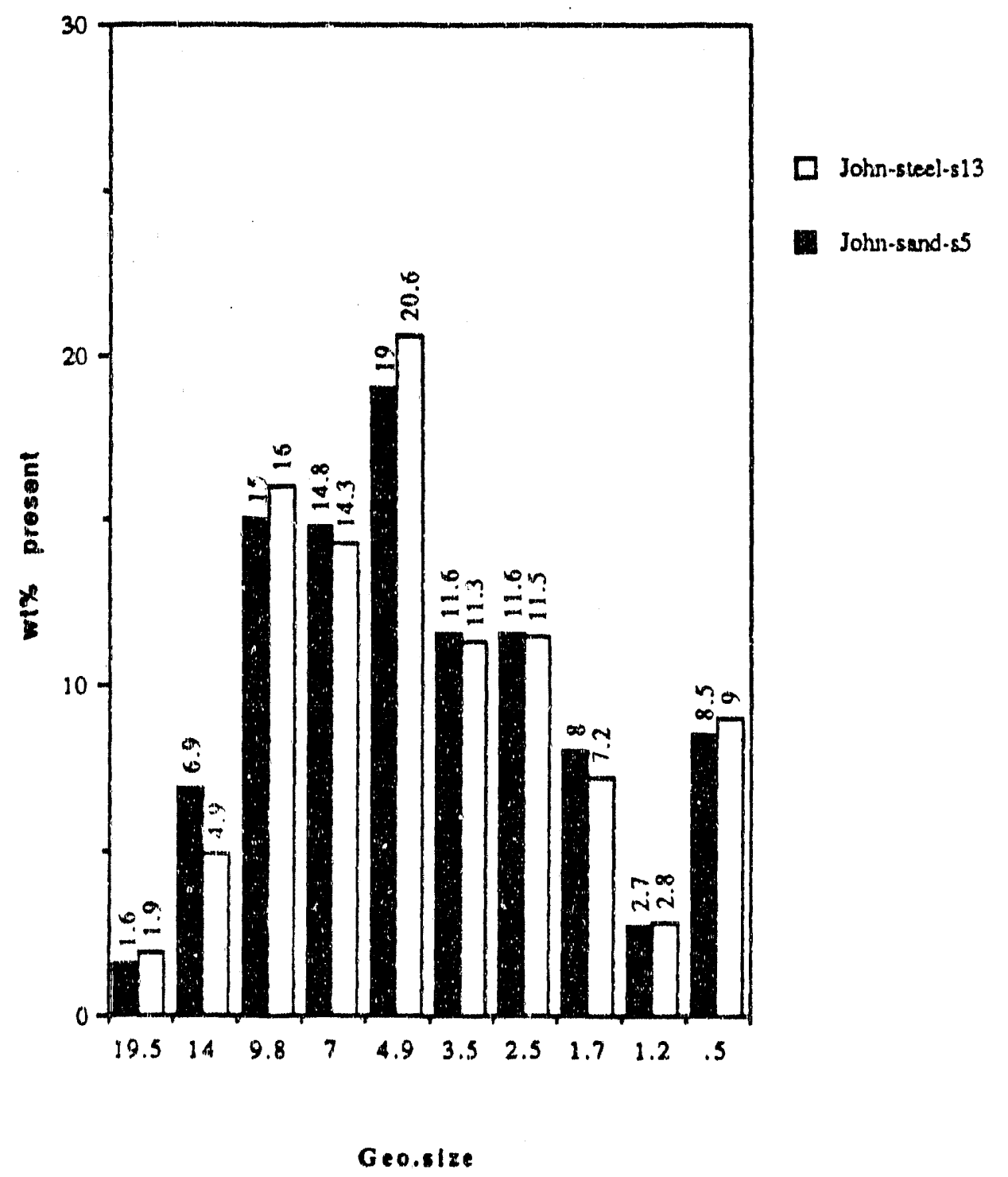

Figure 4-7. EFFECT OF MEDIA TYPE ON THE SHAPE OF PARTICLE SIZE DISTRIBUTION AT SIMILAR MEDIAN PRODUCT SIZE 

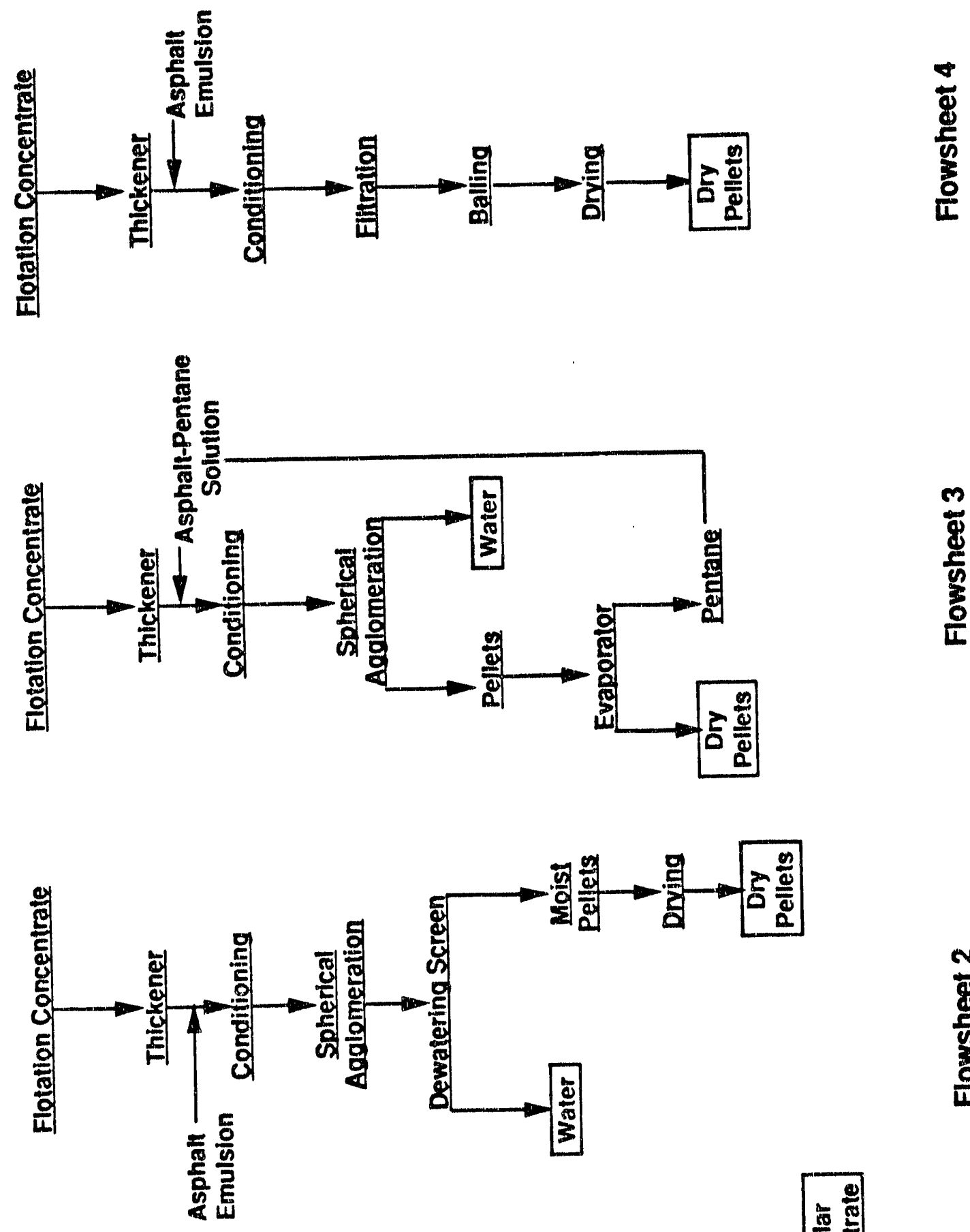

$\frac{m}{d}$
$\frac{0}{4}$
$\frac{0}{5}$
$\frac{1}{1}$
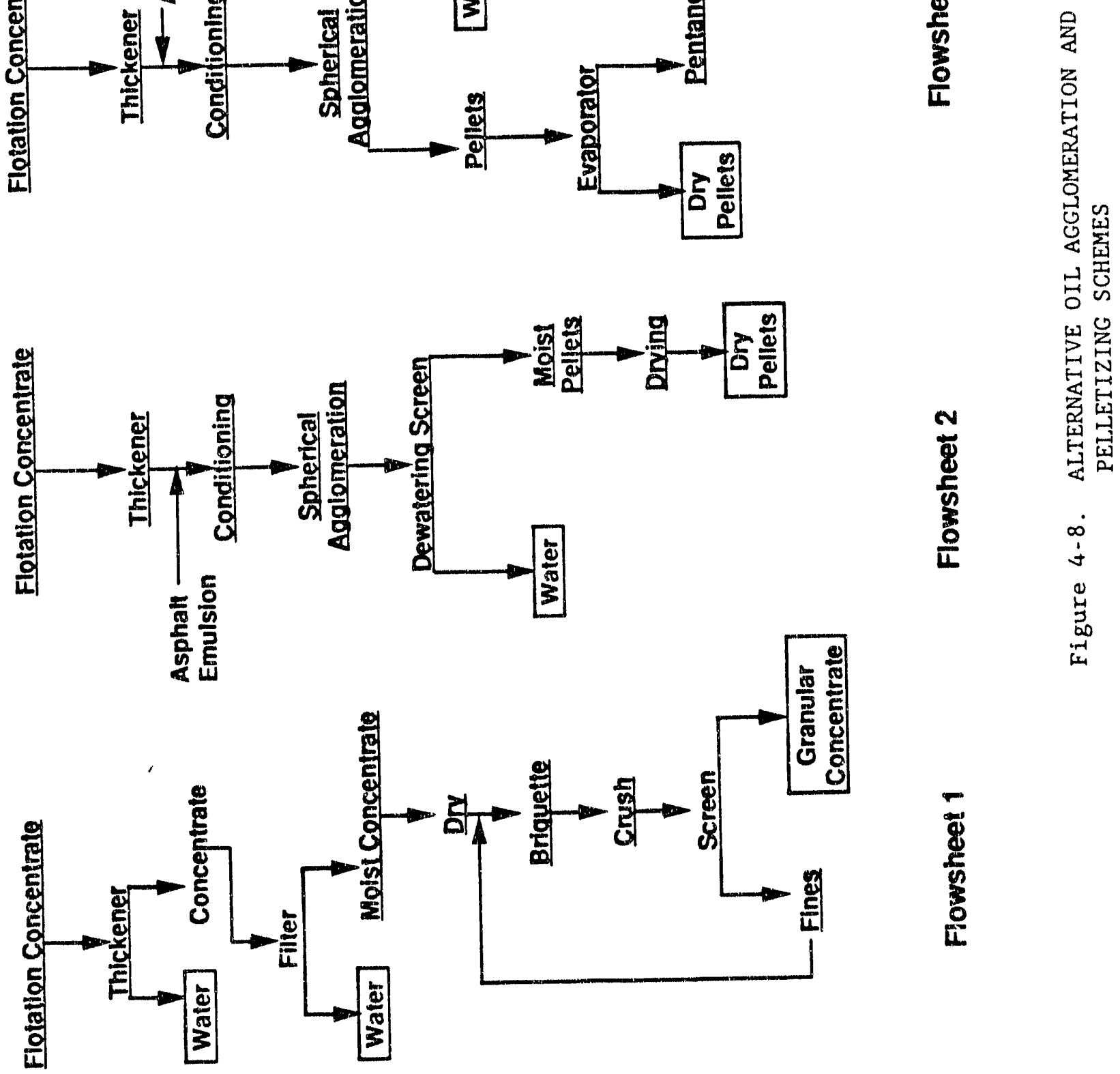

$\frac{N}{\$}$
$\frac{5}{5}$
$\frac{9}{14}$ 
showed the conditioned samples filtered at the same rate as unconditioned samples and were about squal in moisture content. The filter cake from the conditioned samples however did appear to be more cohesive than that formed from concentrate without added asphalt.

One concentrate sample was conditioned with the addition of 20 milliliters of $n$-pentane $/ 100$ grams of concentrate. This sample showed a strong phase separation along with a high level of air entrainment. The n-pentane evaporated rapidly and the residue was not cohesive.

In a parallel, separately funded study of coal agglomeration a factorial experiment on the same conditioning step was conducted. Four factors were studied: asphalt concentration, conditioning speed, conditioning time, and solids content. The size distribution of the coal was measured before and after conditioning. It was found that conditioning time was the most important factor causing an increase in particle size (agglomeration). Asphalt concentration while a factor was much less important. MRI will extend these results to oil shale concentrate.

Next quarter, MRI will conduct oil agglomeration tests using extended periods of agitation. The vessel in which the conditioning step is conducted is being modified to minimize the level of entrainment during conditioning. Air entrainment, while alding phase separation, appears to retard agglomeration. Conditioning tests will also include higher slurry densities and higher asphalt concentration.

\section{Subtask 4.6.2. Bioflocculation of Kerogen}

The objective of this subtask is to use hydrophobic microorganisms to selectively flocculate keroger from enriched flotation concentrate to produce an ultrahigh grade product and simultaneously enhance subsequent dewatering of the concentrate. Another objective of the subtask is to use hydrophobic microorganismls as precursors for oil-assisted spherical agglomeration to produce oil enriched-water repellent kerogen agglomerates. This subtask is being conducted by the University of Nevada, Reno (UN).

During the quarter, UN conducted flocculation tests to investigate the effects of pH and microorganism concentration. The predried solids concentrate (containing 26 percent organic carbon) was suspended in water for 30 minutes and the slurry was mixed at $90 \mathrm{rpm}$ for 10 minutes. After 10 minutes of mixing, the slurry was diluted and dispexsed again with ultrasonic treatment. Initial experiments with the diluted slurry containing 1 weight percent solids showed that the critical concentration of microorganisins for flocculation should be about $70 \mathrm{ppm}$ or more. As a result, most of the flocculation experiments were conducted at that concentration. Flocculation and settling rates of kerogen concentrate for varlous $\mathrm{pH}$ values are given in Figures 4.9 through 4-12. The flocculation and setting rate of kerogen is increased with the addition of Mycobacterium phlei. Good pyrite and ash rejection was noticed in an alkaline $\mathrm{pH}$. Elemental analysis showed that the organic carbon content in the sediments was in the range of 32 to 35 percent compared to the original feed, which had 26 percent carbon. At an acidic $\mathrm{pH}$ of 4.6 , no significant difference in the settling rate was observed after 5 minutes with 


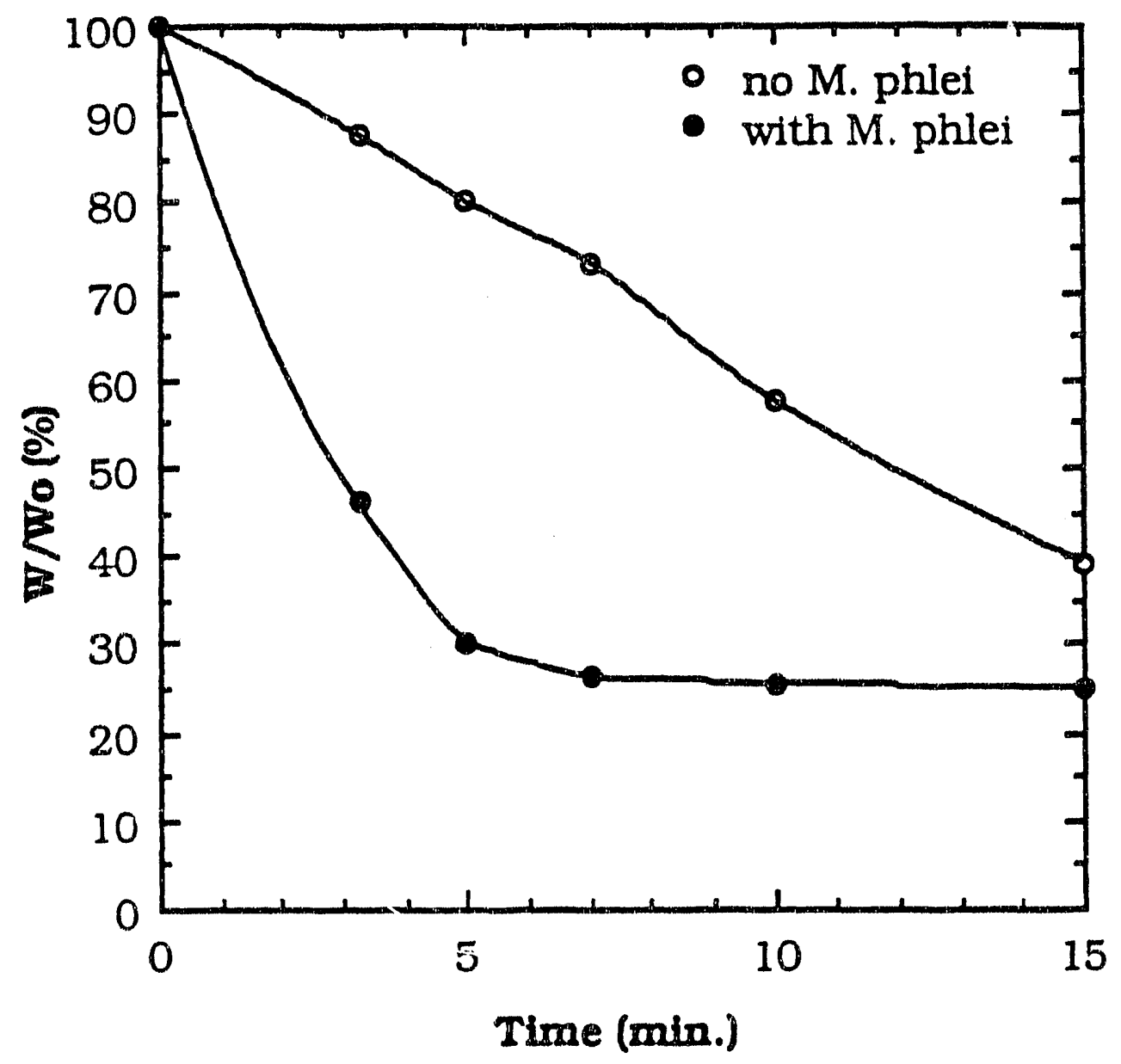

Figure 4-9. SETTLING CHARACTERISTICS OF BENEFICIATED ALABAMA SHALE ( 1.0 wt solids, $\mathrm{pH} 7.3$, phlei $-70 \mathrm{ppm}$ ) 


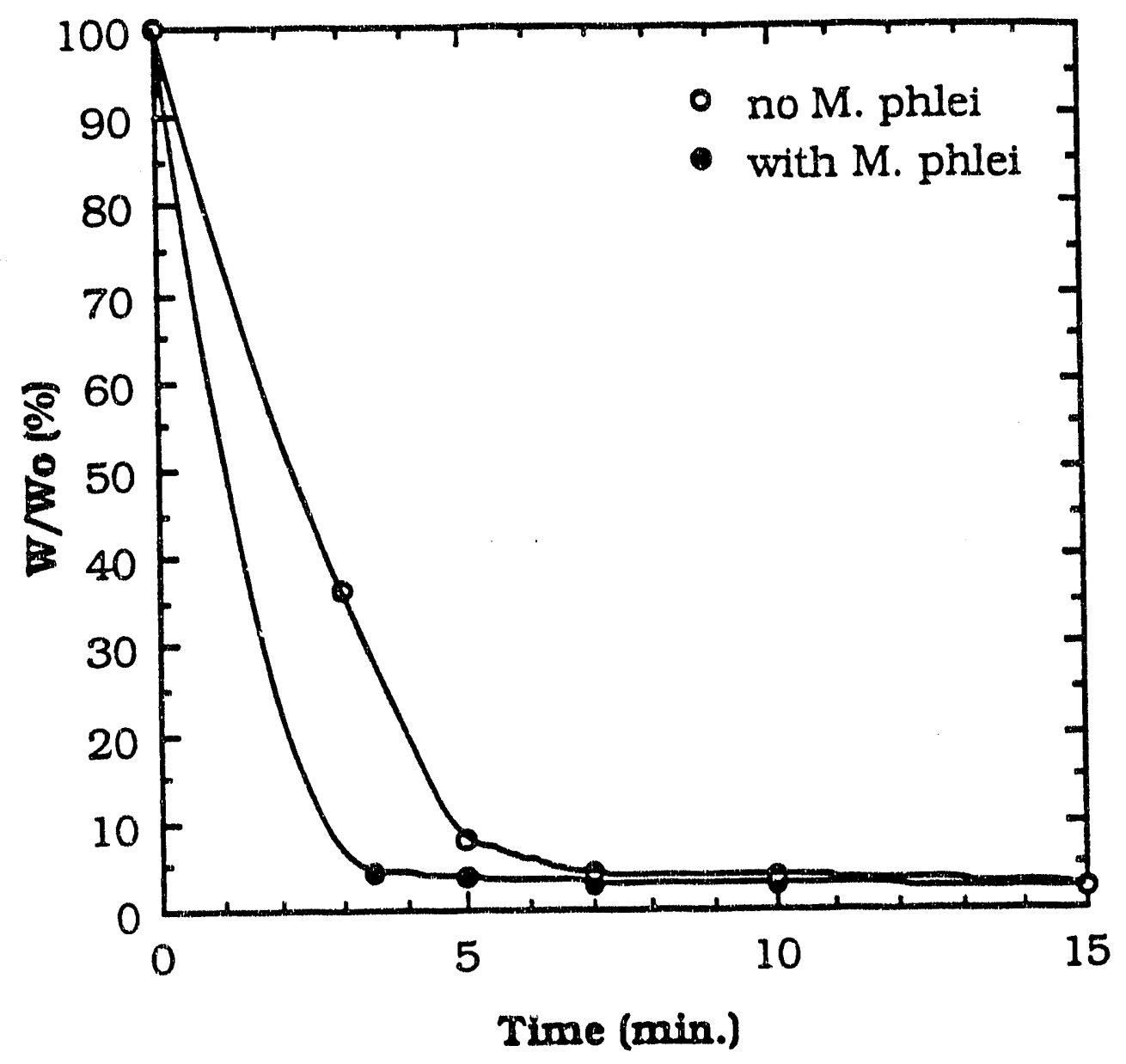

Figure 4-10. SETTLING CHARACTERISTICS OF BENEFICIATED ALABAMA SHALE ( 1.0 wt o solids, $\mathrm{pH} \mathrm{4.6,} \mathrm{M} \mathrm{phlei}=70 \mathrm{ppm}$ ) 


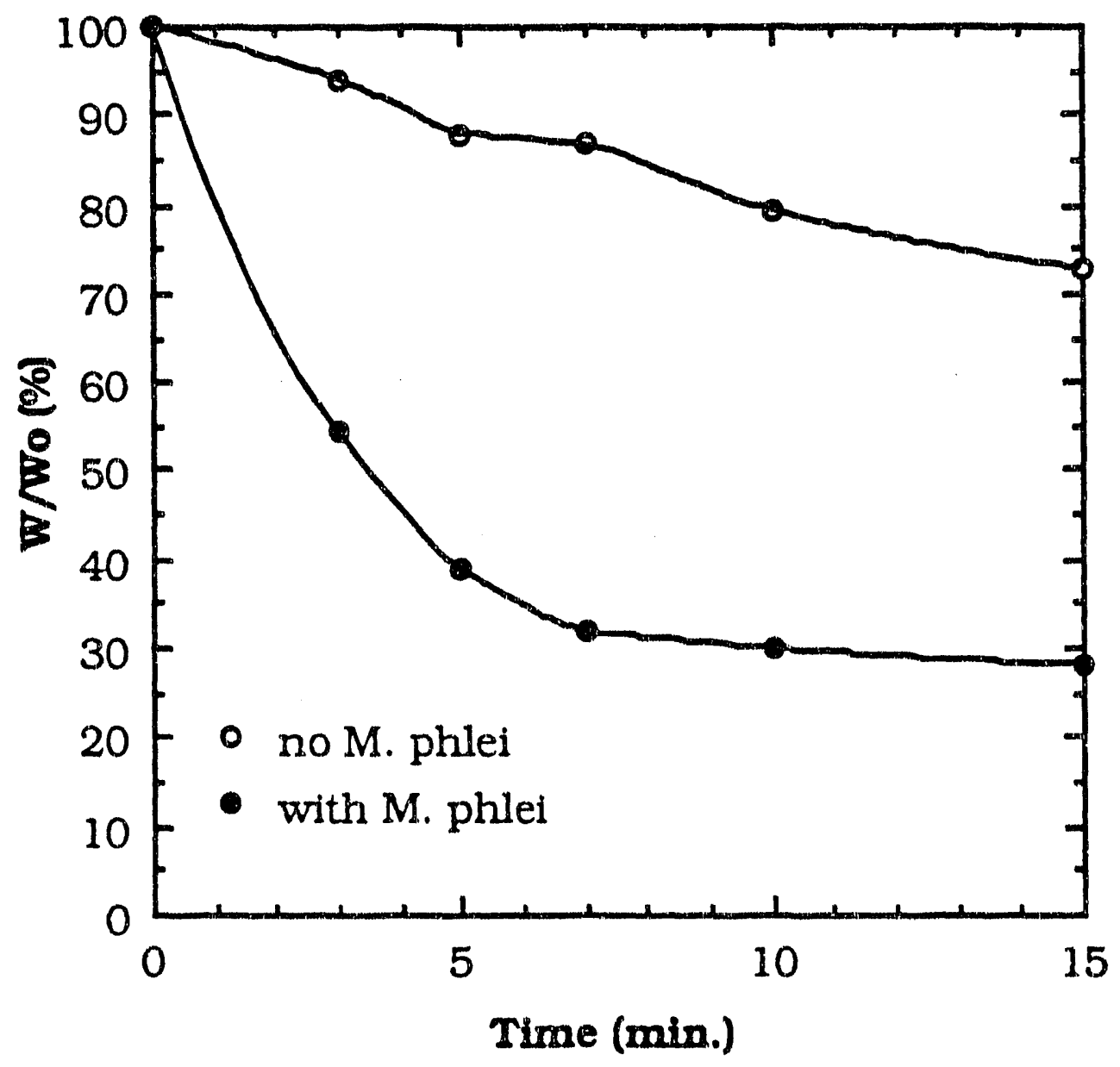

Figure 4-11. SETTLING CHARACTERISTICS OF BENEFICIATED ALABAMA SHALE ( 1.0 wt solids, $\mathrm{pH} \mathrm{9.4,} 1$ phlei $=70 \mathrm{ppm}$ ) 


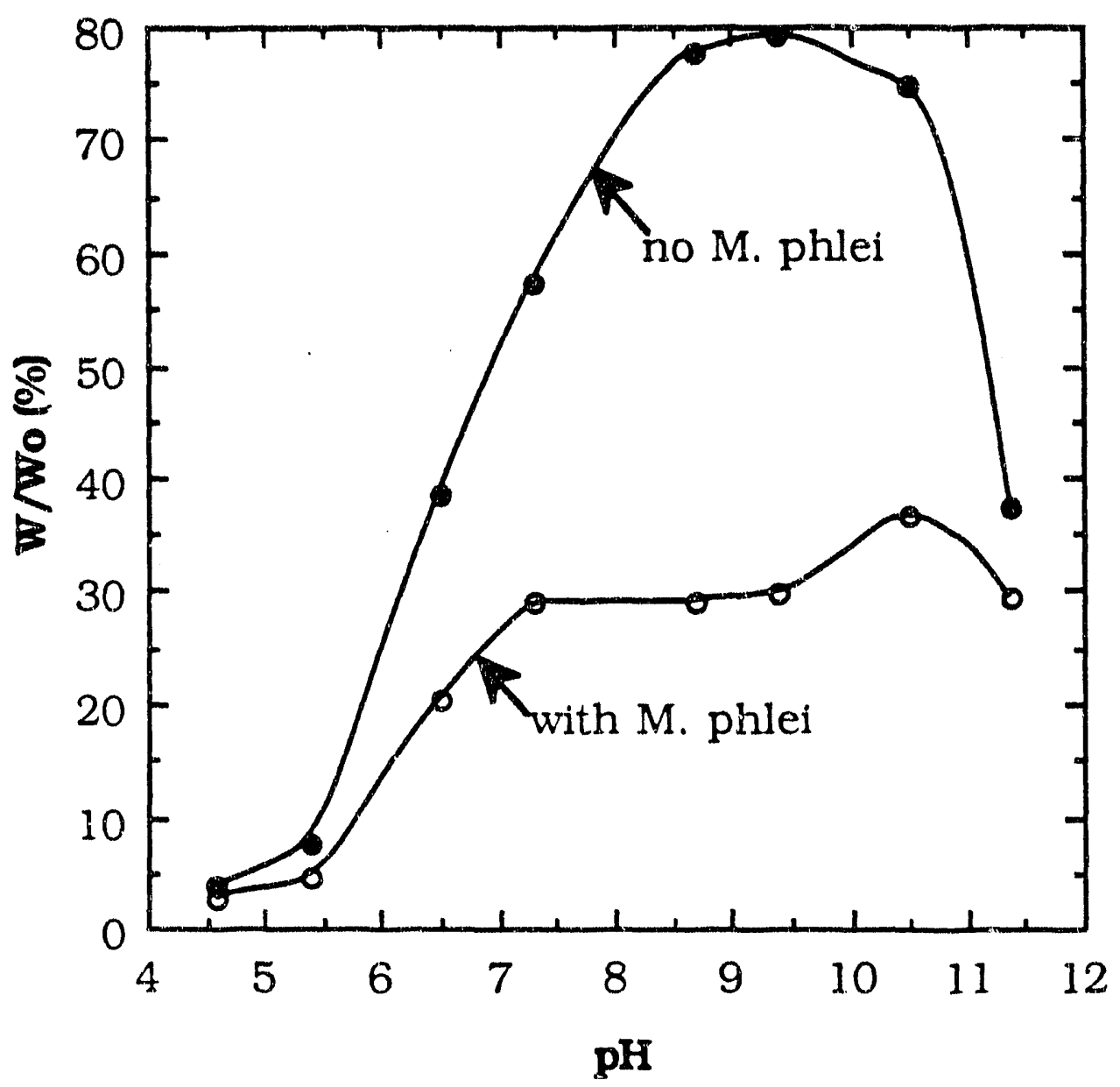

Figure 4-12. EFFECT OF pH ON SETTLING CHARACTERISTICS OF BENEFICTATED ALABAMA SHALE (10 min settling time,

M. phlei - $70 \mathrm{ppm}, 1.0$ wt of soli.ds) 
and without organisms. However, for a settling time of less than 5 minutes, bacterial addition had a positive effect on the initial flocculation and settling. As reported earlier, the inherent flocculation of kerogen in an acidic $\mathrm{pH}$ was due to the aggregation of kerogen particles near the isoelectric point. Optical microscopic examination showed that the size of the flocs with the addition of organisms was large and held strongly by bacterial adhesion and bridging. A scanning electron micrograph of flocculated kerogen with $\underline{M}$ phlef is shown in Figure 4-13. The organism is strongly attached to the kerogen particles. Under simflar conditions, $\underline{M}$ phlei was not attached either to pyrite or to clay particles.

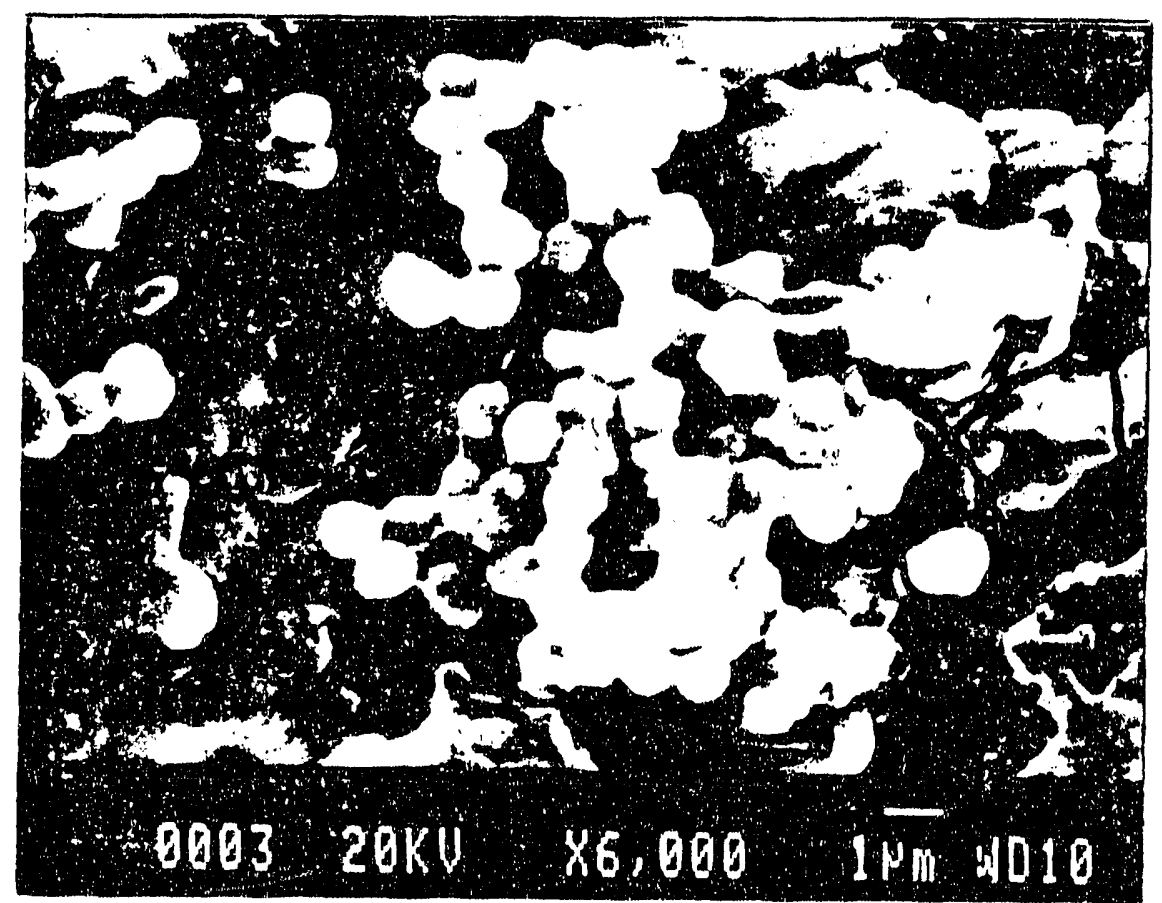

Figure 4-13. SCANNING ELECTRON MICROGRAPH OF KEROGEN WITH Mycobacterium phleI 
The flocculation and settling of freshly prepared flotation concentrate (prepared by conventional flotation at UN) is presented in Figure 4-14 as a function of $\mathrm{pH}$. Flocculation characteristics of the freshly prepared sample were slightly different from that of the dxy sample. However, in both cases, improved carbon content was noticed in the sediments. These preliminary results suggest that initial flocculation with organisms in a moderately alkaline $\mathrm{pH}$ and subsequent flocculation by $\mathrm{pH}$ adjustment to 3 to 4 will improve both the quality of the product and settling rate. Although preliminary in nature, it is estimated that more than 80 percent of the water present in the slurry can be recycled and/or recovered in a very short time by using conventional thickener with addition of $\underline{M}$ phle1. It was determined that the recycled water (decanted) did not have any deleterious effect on the subsequent flotation of kerogen.

Next quarter, UN will evaluate the filtration rate of flocculated sediments and the effect of recycled water on flotation performance.

Task 5. Operation of PFH on Beneficiated Shale

The objectives of this task are to expand the PFH data base by conducting laboratory- and bench-scale tests with beneficiated Alabama shale, and characterize the effluent streams from these tests. This task is divided into two subtasks: 5.2.1. (Laboratory-Scale Tests) and 5.2.2. (Beinch-Scale Continuous Tests), which will be performed by IGT.

\section{Discussion}

During the quarter, work was completed on several equipment modifica. tions planned for the AMRR (advanced multipurpose research reactor), which will be used for bench-scale testing of beneficiated shale. These improvements include the addition of new feed and residue screw controllers and counters, modification of the residue screw flights, and modification of the EST (environmental sampling train) to ensure that only Teflon'-coated surfaces come in contact with the acid and base scrubs. Tests in the bench-scale unit will begin next quarter.

Task 6. Environmental Data and Mitigation Analyses

The overall objectives of Task 6 are to obtain environmental data relating to $\mathrm{PFH}$ and shale beneficiation, and also to analyze the potential environmental impact of the integrated $\mathrm{PFH}$ process. This task is divided into four subtasks: 6.1. Characterization of Processed Shales, 6.2.2 Wastewatex Treatability, 6.4.1. PFH Process Analyses, and 6.4.3. Plant Energy Optimization.

\section{Subtask 6.1. Characterization of Processed Shales}

The objective of this subtask is to determine the effects of $\mathrm{PFH}$ processing on the physical and chemical characteristics of raw and spent beneficiated shale. 


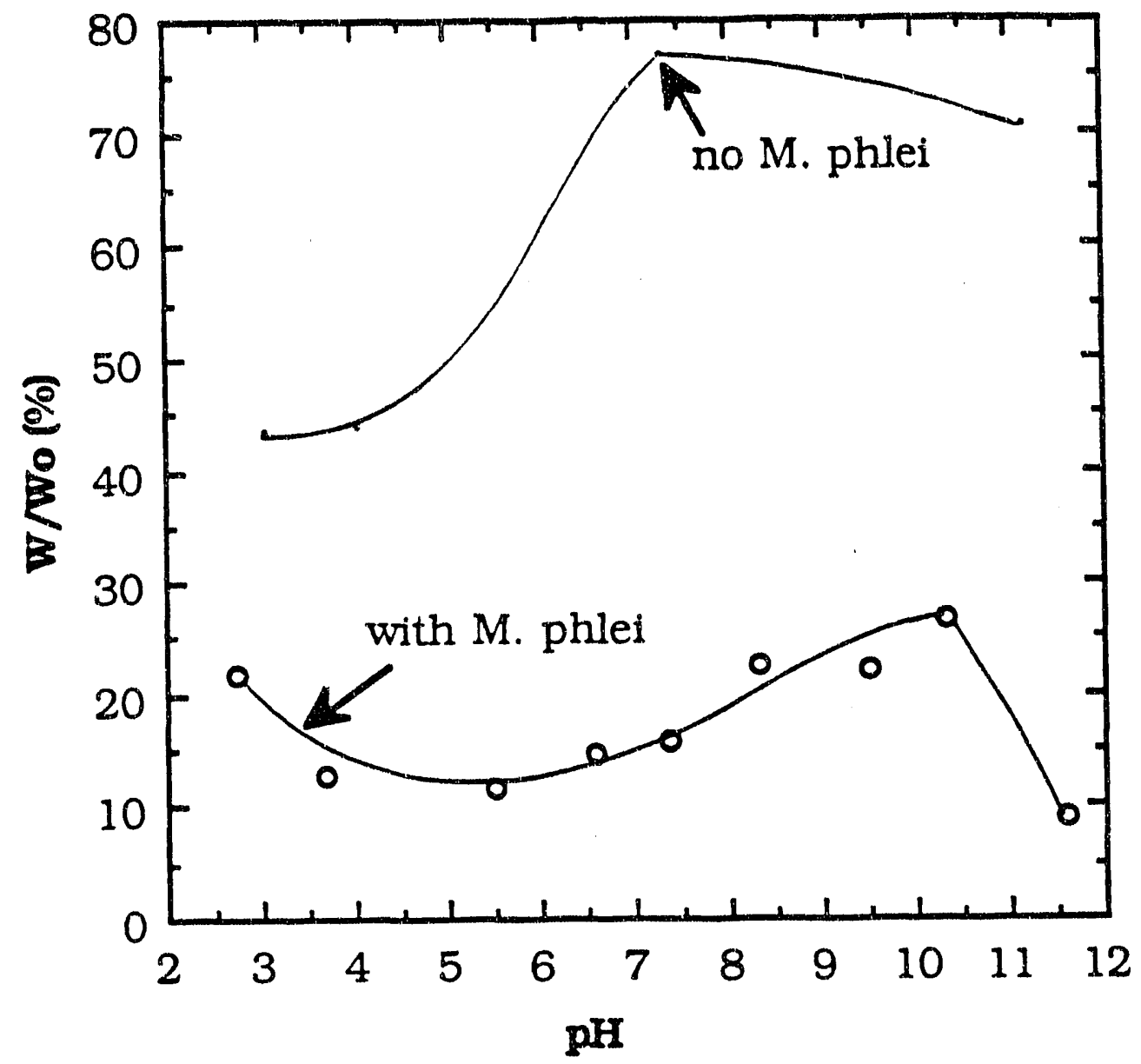

Figure 4-14. EFFECT OF pH ON SETTLING CHARACTERISTICS OF FRESHLY PREPARED BENEFICIATED ALABAMA SHALE ( 5 min settling time, $M$. phlei $=100 \mathrm{ppm}, 0.5$ wt $\&$ solids) 


\section{Discussion}

This subtask will be initiated next quarter when appropriate samples of hydroretorted shale are available from the laboratory- and bench-scale units.

\section{Subtask 6.2. Water Availability and Treatment Studies}

Subtask 6.2.2. Wastewater Treatab111ty

The objective of this subtask is to determine suitable techniques for treating wastewater generated during shale processing. Tennessee Technological University (TTU) is conducting the work on this subtask.

\section{Discussion}

During the quarter, TTU continued evaluating the use of gas chromatography (GC) as an analytical tool for deterxining the concentration of the four organic compounds present in the PFH pxocess water. Problems were encountered in analyzing for some of the compounds using a packed column. Therefore, a capillary column was installed and testing of this column was initiated.

Acclimation procedures with 4-methyl pyridine also continued during the quarter. An evaluation of this compound as a nitrogen source for microorganisms utilizing one of the other compounds of interest as a carbon source was initiated.

Biological treatability studies continued with phenol and MEK. Five additional experiments were conducted with phenol and one with MEK. All of the experiments used 1.5-1iter reactors with varying concentrations of the compounds.

In the phenol experiments, both the change in COD (chemical oxygen demand) and phenol with time were determined. Phenol experiments 2 through 6 were performed using initial phenol concentrations of 100,250 , and $450 \mathrm{mg} / \mathrm{L}$. Figure 6-1 shows the stabilization of the chemical oxygen demand with time for each of these concentrations for experiment 6 . Stabilization began within 10 hours and was completed for reactors containing 100 and $250 \mathrm{mg} / \mathrm{L}$ after about 35 hours, and about 58 hours for $450 \mathrm{mg} / \mathrm{L}$. A comparison of the results from tests 2 through 6 is presented in Table 6-1. As the data in the table show, experiment 6 maintained the initiation and completion times, for the removal of COD, that were observed in experiments 4 and 5 . The differences observed are considered to be within reasonable limits for heterogeneous biological populations. The differences between experiments 2 and 3 , and 4,5 , and 6 are attributed to continuing acclimation of the microorganisms to the phenol.

Comparative plots of the phenol and the COD concentrations for experiment 6 are shown in Figures 6-2 through 6-4. These figures, along with similar data from experiments $2,3,4$, and 5 , indicate that the change in $C O D$ can be attributed to the biodegradation of the phenol. From the batch experiments for phenol that have been conducted to date, the following conclusions can be drawn. 


\begin{tabular}{||c||c|c||c|c||c|c||}
\hline \multicolumn{3}{|c|}{ Table 6-1. COMPARISON OF PHENOL BATCH EXPERIMENTS 2 THROUGH 6} \\
\hline Reactor & Phenol $-100 \mathrm{mg} / \mathrm{L}$ & Phenol $-250 \mathrm{mg} / \mathrm{L}$ & \multicolumn{2}{|c||}{ Phenol $-450 \mathrm{mg} / \mathrm{L}$} \\
\hline \multirow{3}{*}{ Experiment } & $\begin{array}{c}\text { Start } \\
(\mathrm{hrs})\end{array}$ & $\begin{array}{c}\text { Complete } \\
\text { (hrs) }\end{array}$ & $\begin{array}{c}\text { Start } \\
\text { (hrs) }\end{array}$ & $\begin{array}{c}\text { Complete } \\
\text { (hrs) }\end{array}$ & $\begin{array}{c}\text { Start } \\
\text { (hrs) }\end{array}$ & $\begin{array}{c}\text { Complete } \\
\text { (hrs) }\end{array}$ \\
\hline 2 & 30 & 75 & 30 & 90 & 30 & 120 \\
\hline 3 & 20 & 80 & 20 & 80 & 20 & 130 \\
\hline 4 & 15 & 40 & 15 & 55 & 15 & 40 \\
\hline 5 & 10 & 41 & 10 & 41 & 10 & 41 \\
\hline 6 & 10 & 35 & 10 & 35 & 10 & 58 \\
\hline
\end{tabular}

1. In a batch aerobic environment with an excess of nutxients, buffered at a neutral pH, and phenol as the only carbon source, phenol was found to be biodegradable over a range of concentrations up to $450 \mathrm{mg} / \mathrm{h}$.

2. A stable growth of microorganisms was achieved with the phenol as the only carbon source within a few days, but complete acclimation of the organisms to the phenol took approximately 60 days.

3. Gas chromatography, through the use of a packed column, can be used effectively for the determination of phenol concentrations in a filtered sample.

In the batch treatability studies with MEK, the initial concentrations used were 50,100 , and $250 \mathrm{mg} / \mathrm{L}$. The change in COD with time for batch experiment 1 is presented in Figur: 6-5. The biodegradation of the MEK began within the first 4 hours 0 i the experiment and was completed for reactors containing 50,100 and $250 \mathrm{mg} / \mathrm{L}$ within about 32 hours.

Next quarter, studies involving the biological treatability of MEK will be completed. Studies to determine the use of 4 -methyl pyridine as a nitrogen source by microorganisms utilizing one of the other compounds as a source of carbon will continue.

\section{Subtask 6.4 .3 Thermoeconomic Evaluation}

The objective of this subtask is to provide an initial evaluation of the PFH plant design from thermodynamic and economic viewpoints. The goals of this study are to identify thermodynamic losses, to assist in developing costeffective solutions to reduce those losses, to improve the understanding of the cost/benefit tradeoffs in the design, and to facilitate future optimization studies. This subtask is also being conducted by TTU.

During the quarter, TTU focused on the detailed exergy analysis of the PFH plant and initiated the thermoeconomic evaluation. In addition, TTU continued development of computer subroutines to simulate the performance of plant components. 


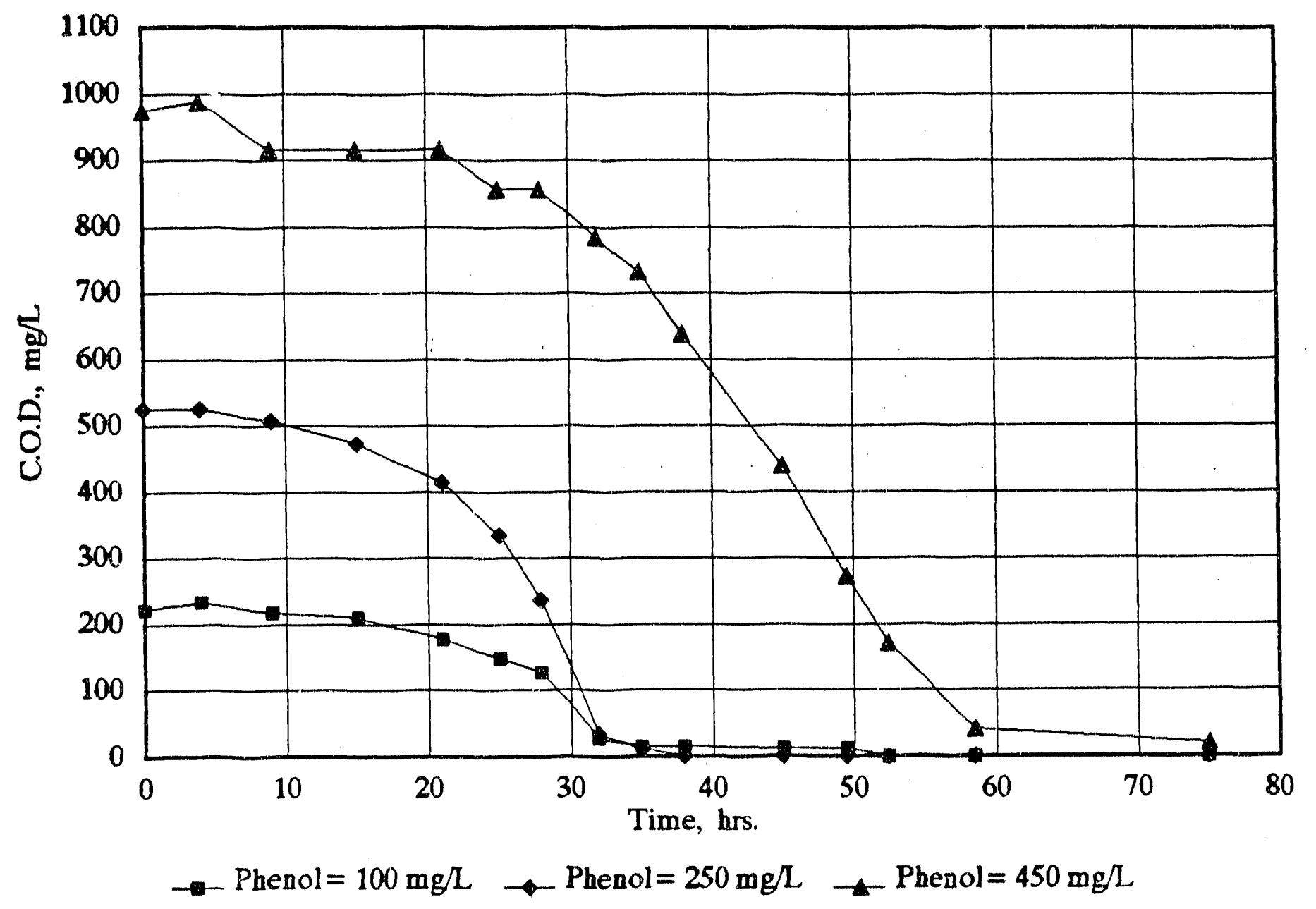

Figure 6-1. COD vs. TIME FOR PHENOL BATCH EXPERIMENT 6

(The Initial Phenol Concentrations were 100,250 , and $450 \mathrm{mg} / \mathrm{L}$ ) 


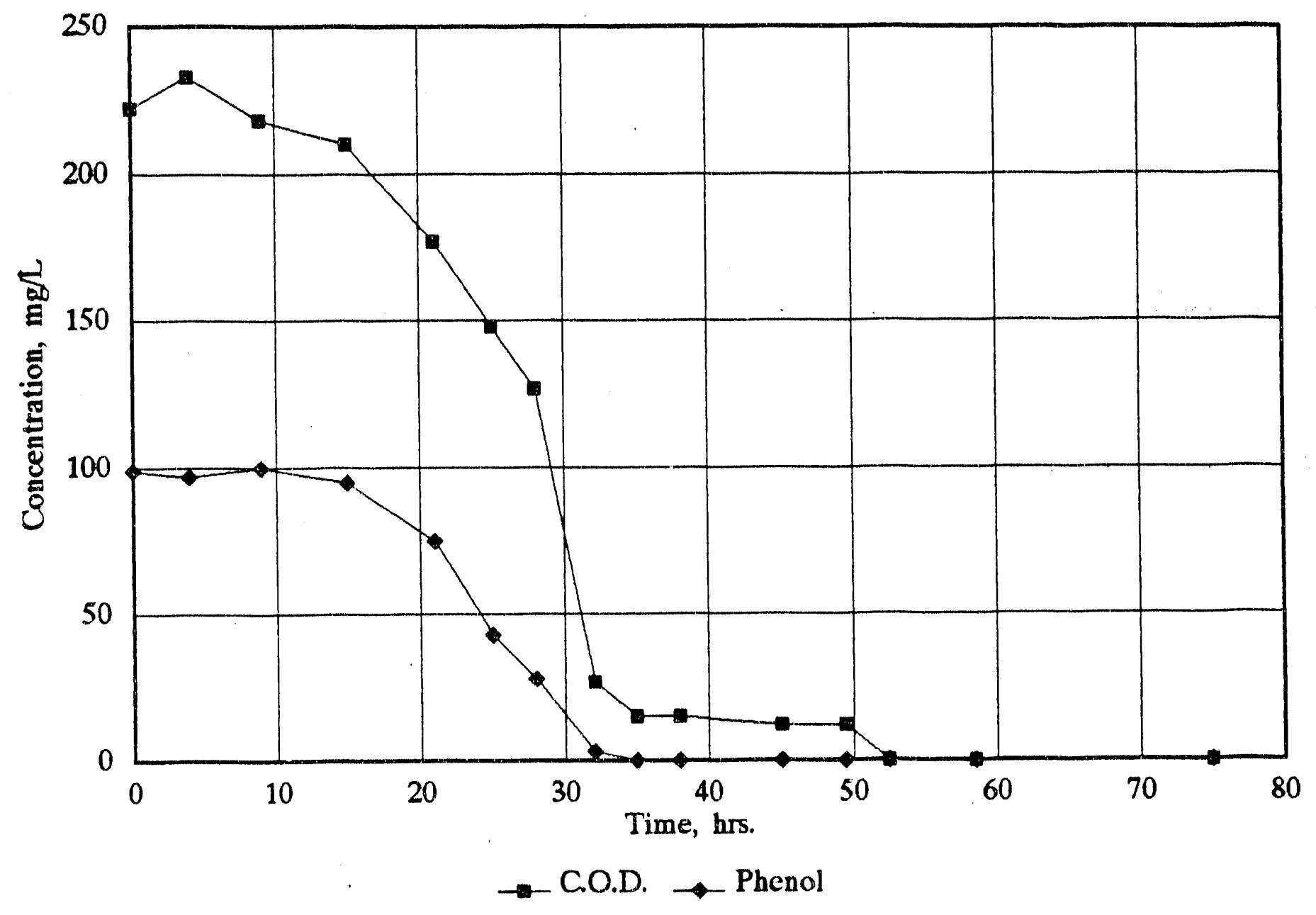

Figure 6-2. COD AND PHENOL vs. TIME FOR PHENOL BATCH EXPERIMENT 6 (The Initial Phenol Concentration was $100 \mathrm{mg} / \mathrm{L}$ ) 


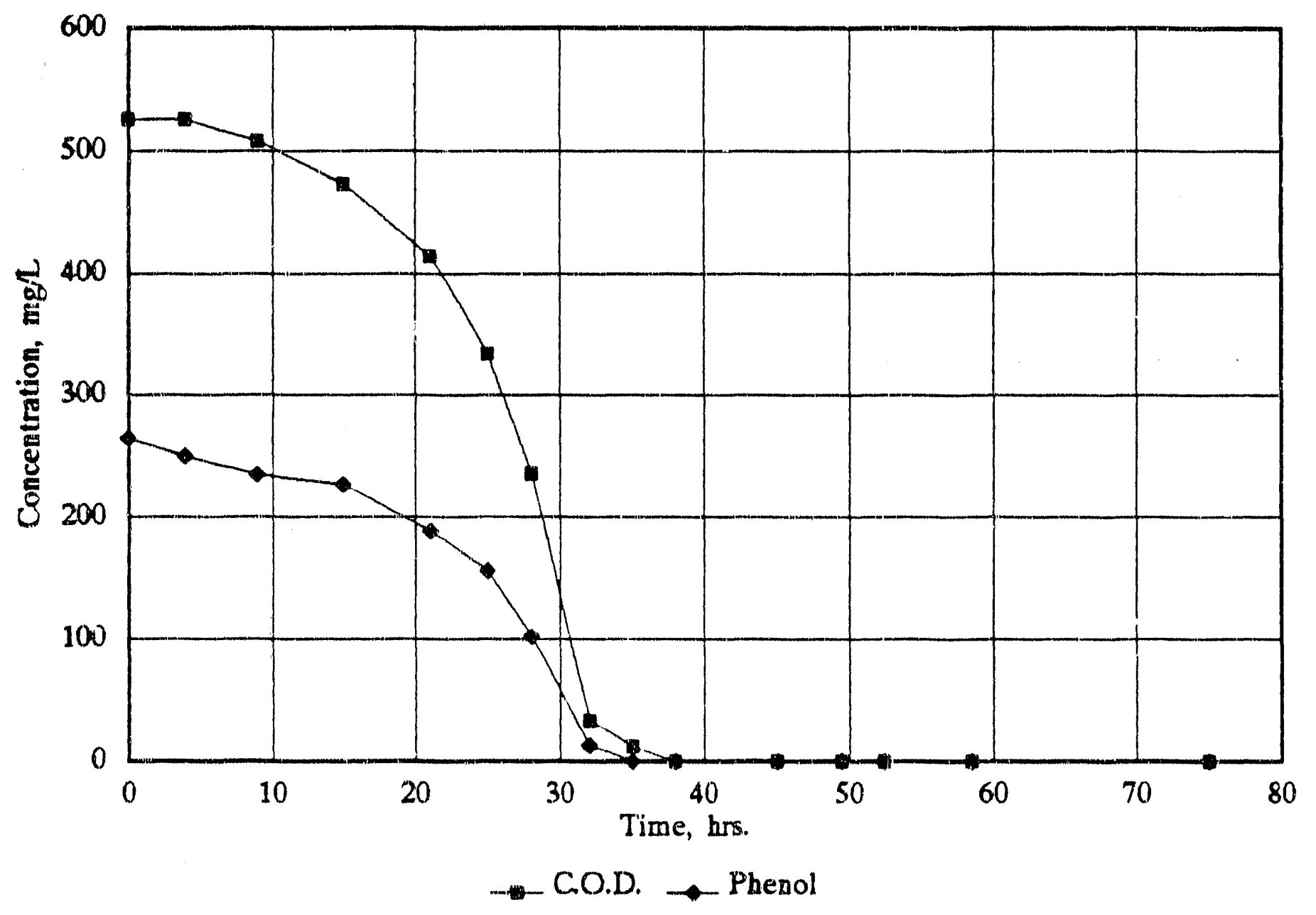

Figure 6.3. COD AND PHENOL vs. TIME FOR PHENOL BATCH EXPERIMENT 6 (The Initial Phenol Concentration was $250 \mathrm{mg} / \mathrm{L}$ ) 


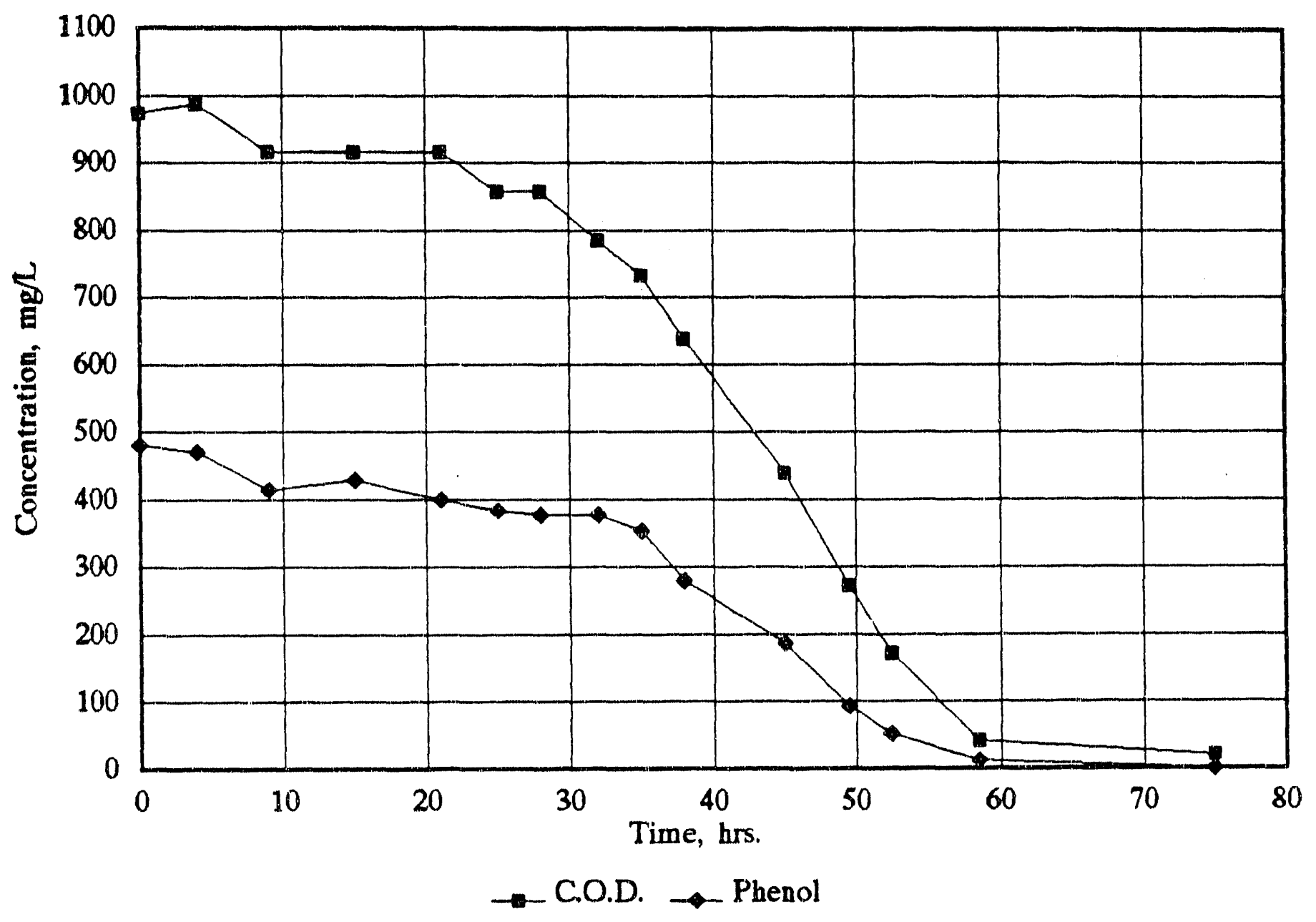

Figure 6-4. COD AND PHENOL vs. TIME FOR PHENOL BATCH EXPERIMENT 6 (The Initial Phenol Concentration was $450 \mathrm{mg} / \mathrm{L}$ ) 


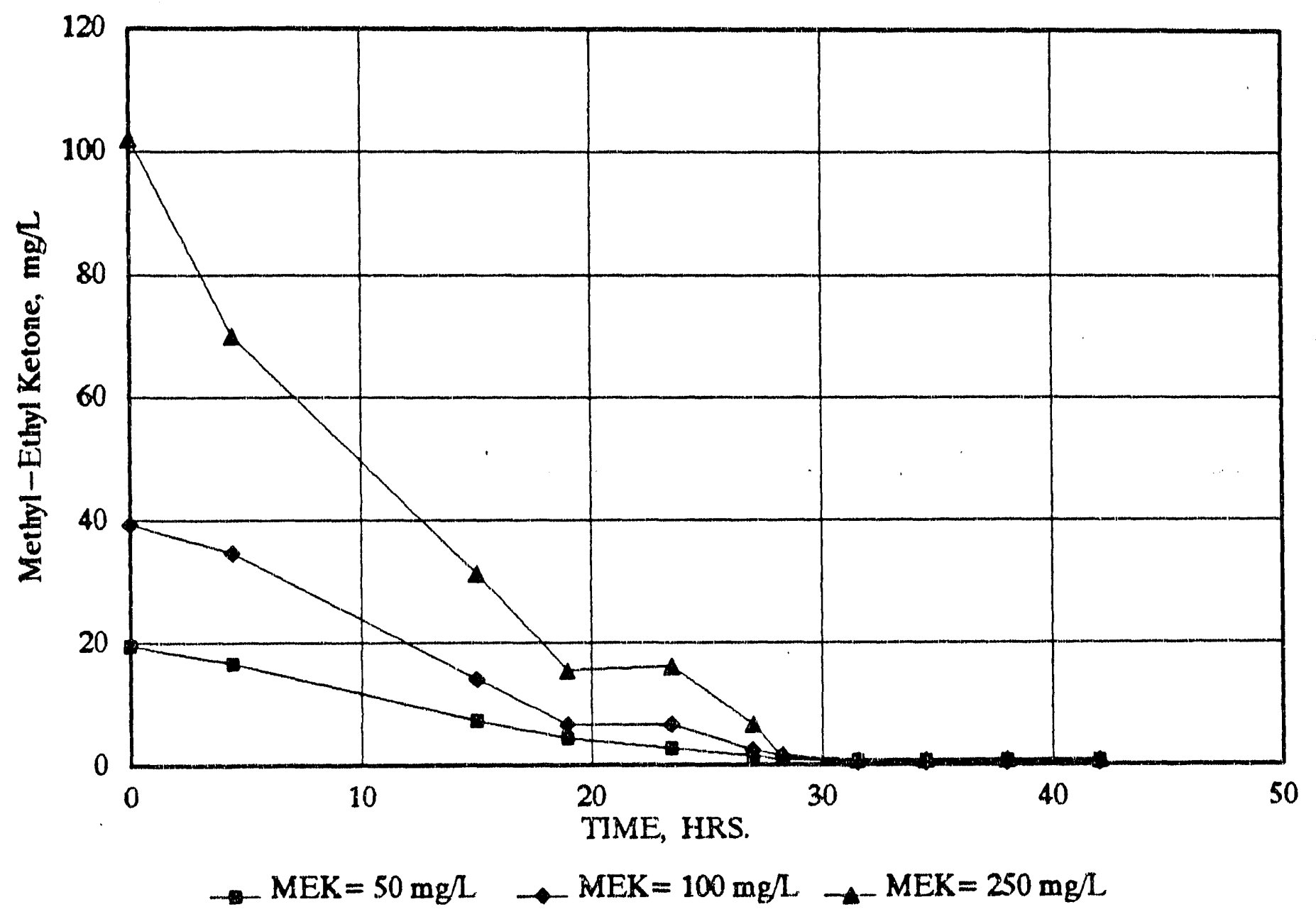

Figure 6-5. MEK vs. TIME FOR MEK BATCH EXPERIMENT 1 


\section{Exergy Analysis}

A preliminary exergy analysis of the PFH plant design, shown in Figures 6.6 (total plant) and 6.7 (hydrogen plant), was performed. The results are presented in Tables A-1, A-2, and A-3 in Appendix A. Table A-1 shows the mass flow rates, temperatures, pressures and the flow rates of enthalpy, entropy and exergy of the material streams in the plant. For each plant component, Table A-2 shows the heat loss, power supplied, exergy destruction flow rate, the exergy destruction ratio (exergy destruction in the component being considered divided by the sum of exergy destruction in the total plant), the ratio between the exergy destruction in the component being considered and the exergy of raw shale supplied to the PFH plant, and, finally, the component exergetic efficiency, which represents the real thermodynamic efficiency of the component. Table A-3 summarizes the mass and heat balances in the steam/water system.

Based on the results presented in Table A-2, several observations can be made. The excessive heat loss in the raw shale preheating indicates that either the temperature of stream 6 must be higher or the temperature of stream 4 must be lower. Either temperature correction will reduce the exergy destruction and will increase the exergetic efficiency of shale preheating. The significant heat loss ( $148.7 \mathrm{NW}$ ) and exergy destruction (almost $75 \mathrm{MW}$ ) in the desalting and hydrotreating unit will be explained after a more detailed flow diagram of this unit is available.

The relatively high exergy destruction in the reformer furnace (150.6 MW) is mainly caused by irreversibilities in (a) the combustion of me thane, (b) the heat transfer from the combustion gases to the steam and gas to be refarmed, and (c) the chemical reactions during the reforming process. Part of the sensible heat of the flue gas leaving the reformer furnace (stream 160) and the fired heater (stream 159) could be used for producing low-pressure steam and for feed water preheating.

The addition of steam (stream 115) to stream 101 in the hydrogen plant: should occur after stream 101 has been preheated in the first heat exchanger. This change would reduce the surface area of this heat exchanger and, thus, the total investment costs. The total exergy destruction will not be affected by this change.

In the hydrogen plant, the two heat exchangers where stream $102 / 103$ is preheated and stream 108/109 is cooled could be combined into one heat exchanger. This change will reduce the total investment costs.

The exergy destruction in the water quenching of stream 106 at the outlet of the reformer furnace is significant $(20.4 \mathrm{MW})$. The thermoeconomic analysis should determine if using an advanced heat exchanger to cool stream $106 / 107$ and stean addition to stream 108 in lieu of the water quenching would improve the overall economics of the PFH plant.

The estimated overall power consumption in the plant is about $100 \mathrm{MW}$. The design and operation of the gas compressors should be optimized from the thermoeconomic viewpoint. In addition, the overall plant economics should be 


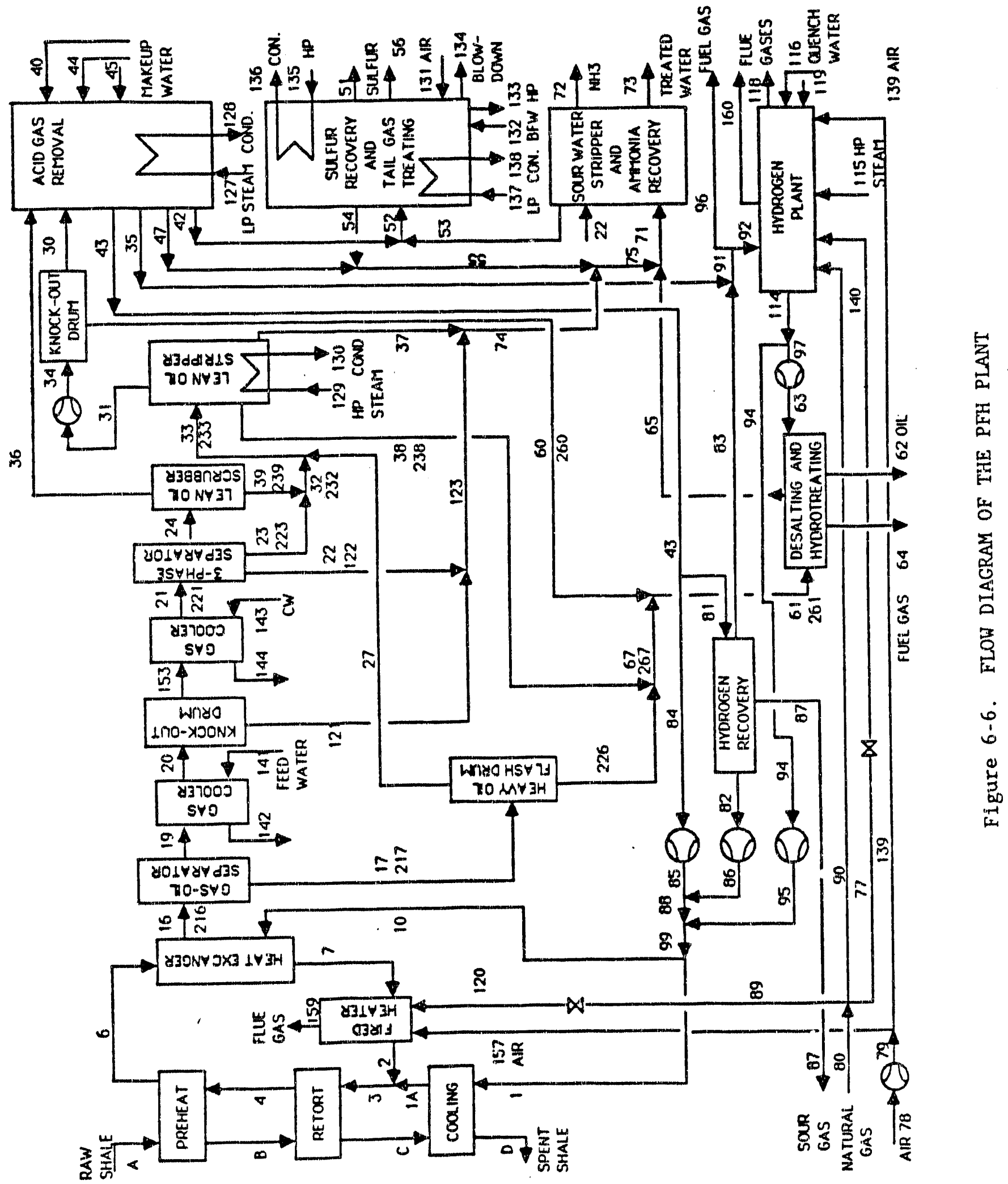




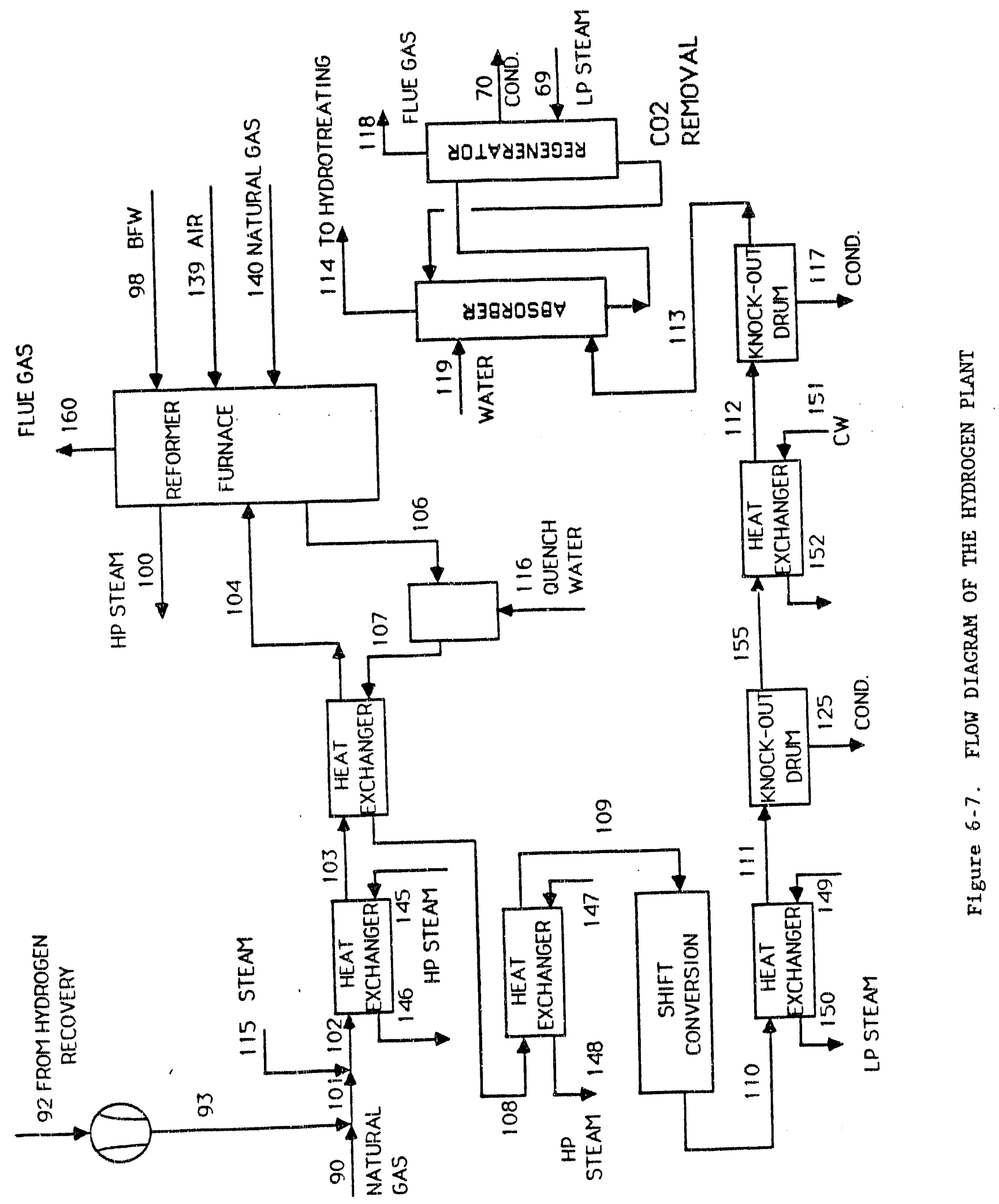


improved through combination of the PFH plant with a combined-cycle power plant (or with an intercooled steam-injected gas turbine), which would use the net steam generated in the plant (Table A-3) and would provide the required electric power.

The overall exergetic efficiency of 84.9 percent shown in Table A-2 for the total plant indicates that the overall plant design is thermodynamically efficient. Some potential, however, still exists for improving the overall efficiency and reducing the costs of the final products.

\section{Thermoeconomic Evaluation}

During the quarter, TTU initiated development of the computer software, the cost balances and the equations required to complete the thermoeconomic evaluation. The development of the equations that TTU will use in the thermoeconomic evaluation is presented in Appendix B.

Next quarter, a first thermoeconomic evaluation will be presented. In addition, work to complete the PFH plant design and to study the effect of important plant parameters on the overall efficiency and costs of the final products will be initiated.

\section{Task 7. Sample Procurement, Preparation, and Characterization}

The objective of this task is to procure, prepare, and characterize raw and beneficiated Eastern oil shale samples for all of the experimental tasks of the program extension.

MRI completed all of the components of this task during the quarter. Chemical analyses of selected products produced during the pilot plant operations at Michigan Technological University (MTU) were completed. The analyses of a head sample, taken by MTU, from the 6 tons of shale shipped from Madison County, Alabama to MTU are presented in Table 7-1. The results show that the sample sent to MTU was significantly lower in Fischer Assay (FA) oil yield than the sample subsequently sent to UK-CAER and that retained by MRI. Analyses of the latter two samples are also shown in Table 7-1.

The difference in the analyses result from the sampling procedure. A 3 ton sample was taken and returned to MRI for preparation for the MRI and UKCAER studies. This sample was wet screened at $1 / 4$ inch to remove mud and hand picked to remove rock fragments not associated with the in-place shale. The slight differences in the UK-CAER and MRI samples can be attributed to large sample mixing problems.

In order to confirm past analytical procedures relating density to carbon content and oil yield, on the MTU head sample returned to MRI, three flotation tests were conducted at 3 different rod mill grinding times for subsequent correlation of these values. No effort was made in those mechanical cell flotation studies to produce high kerogen recovery because of the necessity of producing flotation products with widely varying densities, carbon contents and oil yields. The results of these studies are shown in Table 7-2. 
Table 7-1. ANALYSES OF ALABAMA OIL SHALE HEAD SAMPLES

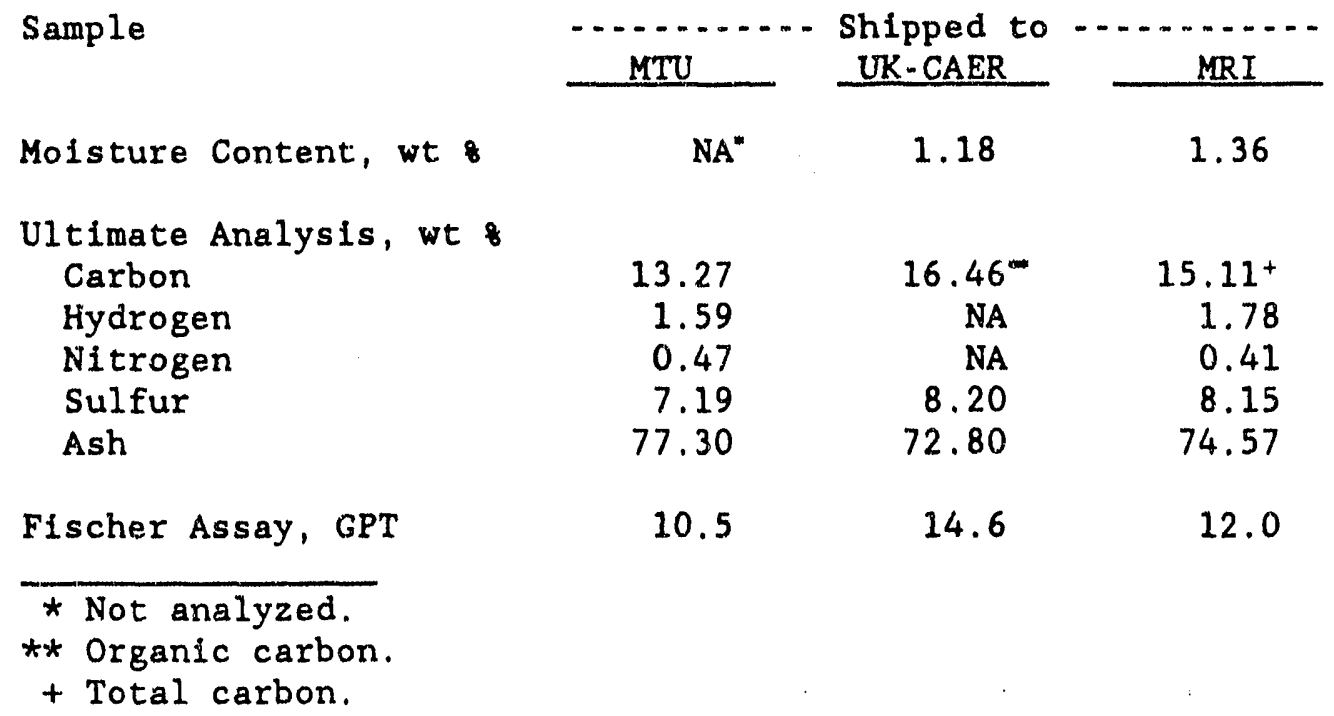

Evaluation of the carbon-density ratios of all the products produced in this test series gave carbon values ranging from 2.37 (underflow samples) to 37.8 percent and density values ranging from 1.87 to $2.83 \mathrm{~g} / \mathrm{ml}$. FA of the flotation concentrates, combined middlings, and tailings products from these tests ranged from 32.4 to $0.6 \mathrm{GPT}$. Calculated FA for the flotation feed in the three tests showed a reduction in oil yield of about 15 percent from the 30-minute grind to the 120-minute grind, as shown in Table 7.2.

Table 7-2. COMPARISON OF FLOTATION RESULTS ON MTU SAMPLE GROUND TO 3 DIFFERENT SIZE CONSISTS

\begin{tabular}{|c|c|c|c|c|c|c|c|c|c|c|}
\hline ris & & & & & Ana & s. wt 8 & & 04 & int & 8 \\
\hline ime, mit & $\mathrm{d}_{\infty}$ & $d_{s 0}$ & & GPT & Carbon & Sulfur & $\mathrm{g} / \mathrm{m} 1$ & oil & C & S \\
\hline 30 & 3 & 1 & 40 & 21 & & & & & & 72 \\
\hline 6( & 2 & 8 & & & & & & & & \\
\hline 120 & 17 & 6 & 18.3 & 32.6 & 37.8 & 15.5 & 1.87 & 65.5 & 55.3 & 39.2 \\
\hline
\end{tabular}

Calculated feed FA, $30 \mathrm{~min}=10.6,60 \mathrm{~min}-10.8,120 \mathrm{~min}=9.0 \mathrm{GPT}$

Analyses of selected flotation feed, concentrate and tailings samples taken by MIU personnel during their continuous grinding and column cells flotation studies; wherein, they were using product densities as the primary process control, have been completed. The MTU studins were two fold in that (1) MTU would produce 1 ton of flotation concentrate for subsequent compaction and sizing prior to PFH studies, and (2) MTU personnel would make comparative studies of data obtained from a MTU packed column flotation cell and a Deister column flotation cell, operating from a common flotation feed. Analyses of: these flotation products for carbon and sulfur have been correlated with density measurements furnished by MTU and compared, in straight line plots, with the carbon, sulfur and oll yield data generated from MRI studies. These data (Figure 7-1) show that the density to carbon ratios of the two sets of data are close but not equal which may indicate some difference in the $10 \mathrm{~kg}$ 
head sample returned to MRI and the tonnage sample treated at MTU. However, the relationship of density to carbon, as well as density to oil, held true for this lower grade sample.

Figure 7-1 also shows the relationship of the response of sulfur, or pyrite, to the flotation conditions. In the case of the MTU sulfur analyses, these data were generated from shale ground to an average $d_{20}$ of about $12 \mu \mathrm{m}$; whereas, the MRI sulfur analyses were generated from shale ground only to a $d_{90}$ range of 36 to $17 \mu \mathrm{m}$. Previous column cell versus mechanical cell test data had indicated that the lower sulfur analyses normally found in column cell concentrates might be a function of column froth helght and/or wash water volume; however, recent mechanical cell concentration of Alabama oil shale ground to a $d_{s 0}$ of $11 \mu \mathrm{m}$ have yielded concentrates containing about 7 percent sulfur. On the basis of these results, the pyrite liberation point is indicated to be in the 10 to $12 \mu \mathrm{m}$ range.

\section{Comparison of types of column cells}

Neither of the large column cells at MTU were able to reproduce the results of MRI studies. The MRI studies utilized a small 4-inch diameter, 63inch tall continuous laboratory-scale column cell, and generated data relating grade to density. A flowsheet (Figure 7-2) shows the system used to produce the feed to the column cells, as well as the disposition of the concentrate and tails from the flotation cells.

Table 7-3 shows a summary of the operating results of the flotation circuit based on density samples take during the course of the pilot plant campaign. Concentrate weight recoveries are also given in this table. The average concentrate weight recoveries should be fairly representative of the overall pilot plant campaign; whereas, the weight recoveries shown for the high and low density measurements indicate that such concentrate weight recoveries could have occurred based on the avallable density of data.

Using the average density values, the average concentrate weight recoveries and determining the carbon content based on a point midway between the MTU and MRI density to carbon values shown in Figure \%-1, material balances for the two column cells are given in Table 7-4. The results show that, under the test conditions, neither of the column cells was effective in yielding high recovery of the kerogen. On an average the MTU packed column gave a higher grade concentrate than was obtained from the Deister column cell. This data also indicated that the overall analyses for the sample treated at MTU was significantly higher than the head sample returned to MRI. The head sample returned to MRI (Table 7-1) contained 13.27 percent carbon and 10.5 GPT of oil compared with the indicated 14.75 percent carbon and 12 GPT of oil shown in Table 7-4.

Because of the low kerogen recovery during this pllot plant campaign only $680 \mathrm{~kg}(1500 \mathrm{lb})$ net weight of concentrate was produced. A head sample of this concentrate, shipped to MRI, gave the results shown in Table 7-5. 


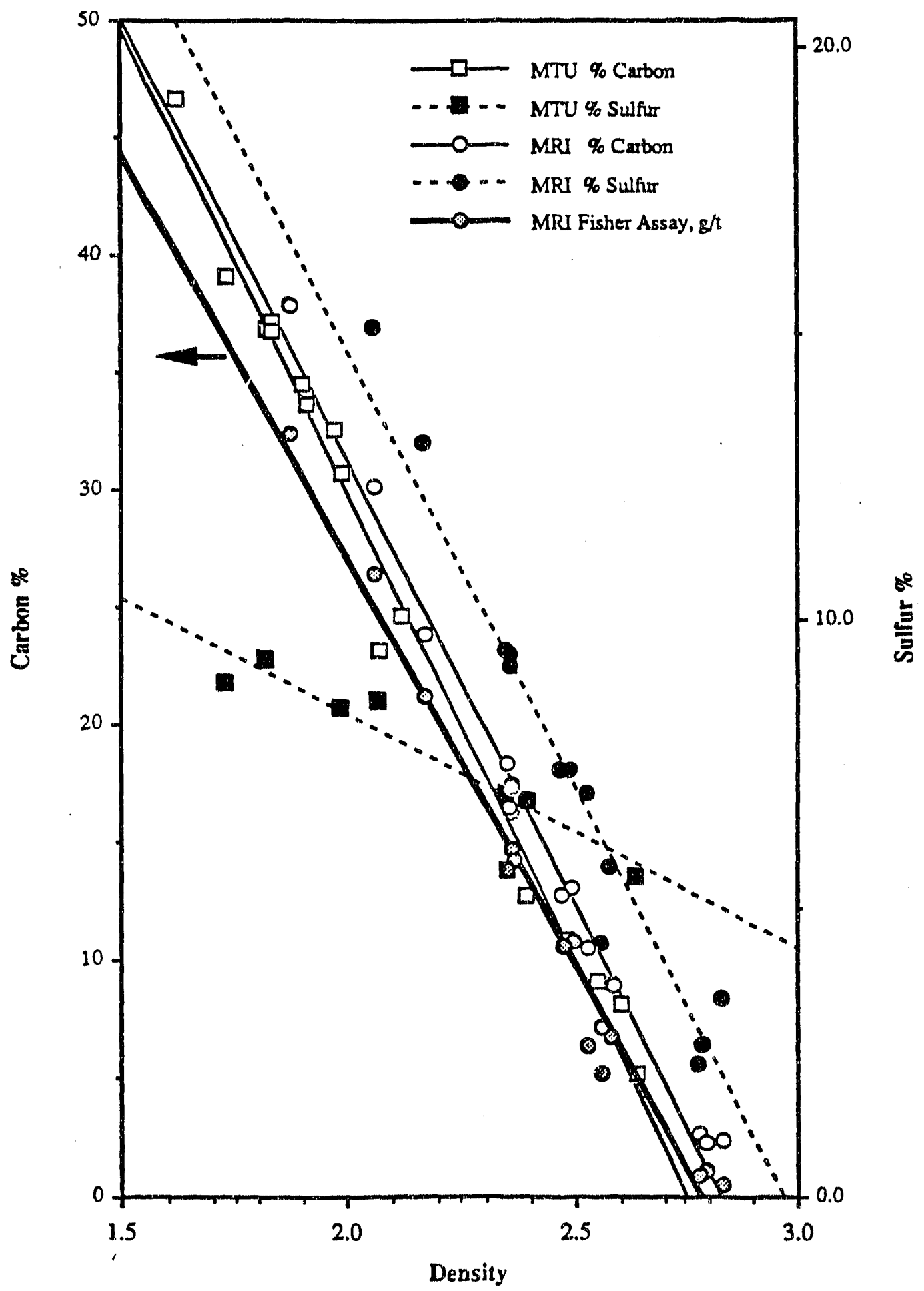

Figure 7-1. CARBON:DENSITY:OIL, MTU COLUMN CELI. vs. MRI MECHANICAL CELL DATA 


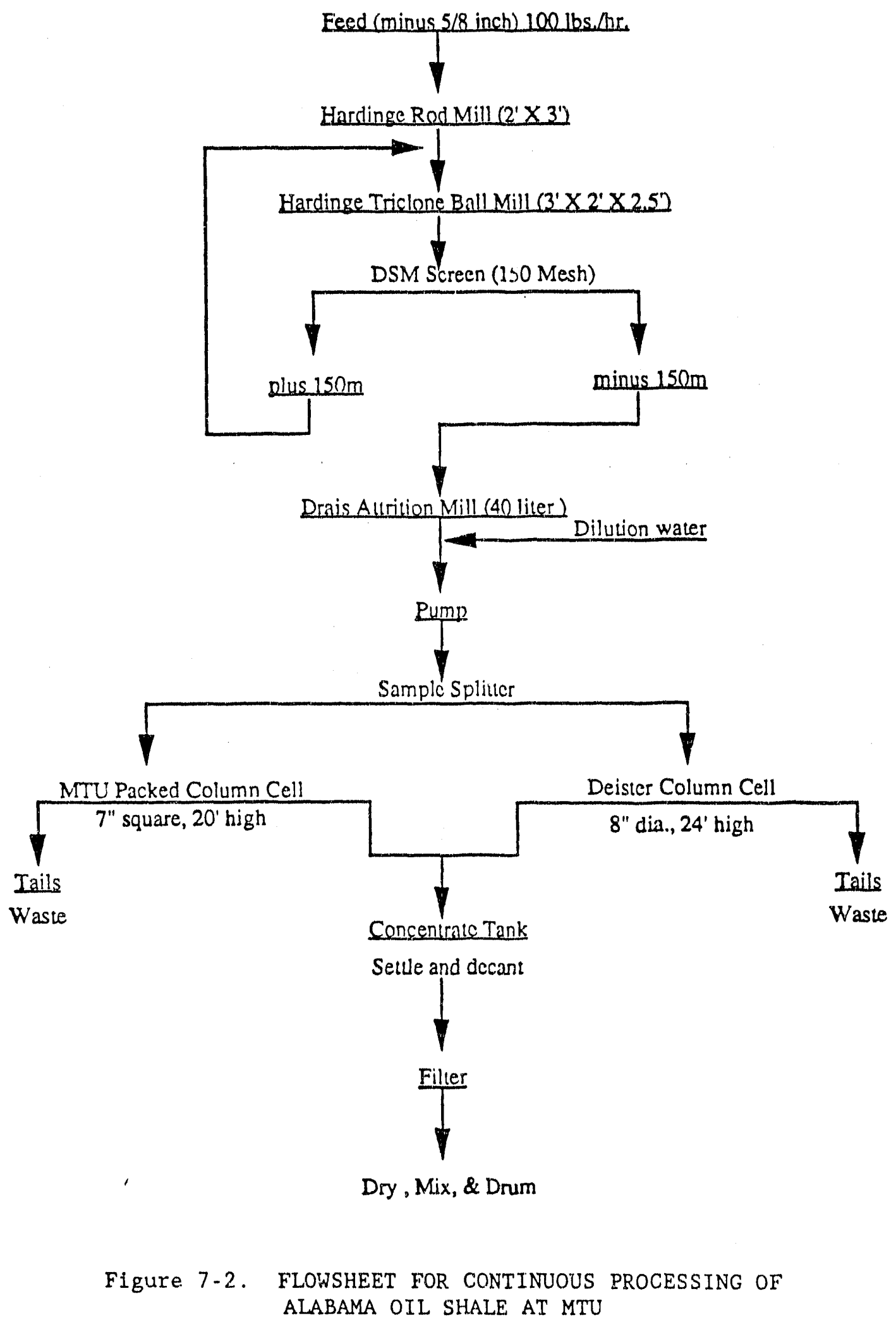


Table 7-3. SUMMARY OF MTU FLOTATION RESULTS BASED ON DENSITY ANALYSES OF SAMPLES

\begin{tabular}{|c|c|c|c|c|c|c|c|}
\hline \multirow[b]{2}{*}{ Product } & \multirow{2}{*}{$\begin{array}{r}\text { No. of } \\
\text { Samples }\end{array}$} & \multicolumn{3}{|c|}{ Density $\mathrm{g} / \mathrm{ml}$} & Conc & \multicolumn{2}{|c|}{ Weight, 8} \\
\hline & & Avg. & High & Low & Avg. & High & Low \\
\hline Column Cell Feed & 11 & 2.41 & 2.46 & 2.35 & $\ldots$ & $\cdots$ & -. \\
\hline MTU Cell Conc. & 12 & 1.79 & 1.92 & 1.62 & 20.5 & 26.0 & 15.1 \\
\hline MTU Cell Tails & 12 & 2.57 & 2.65 & 2.48 & - & $\cdots$ & $\cdots$ \\
\hline Deister Cell Conc. & 13 & 2.00 & 2.12 & 1.97 & 22.6 & 34.6 & 13.5 \\
\hline Deister Cell Talls & 13 & 2.53 & 2.64 & 2.49 & $\cdots$ & -- & -. \\
\hline Final Concentrate & 10 & 1.90 & 1.97 & 1.82 & - & -- & - \\
\hline
\end{tabular}

Table 7-4. AVERAGE MATERIAL BALANCES FOR THE MTU PACKED COLUMN CELL AND THE DEISTER COLUMN CELL

\begin{tabular}{|c|c|c|c|c|c|}
\hline \multirow{2}{*}{ Flotation Product } & \multicolumn{2}{|r|}{ FA, } & \multirow[b]{2}{*}{ Carbon, 8} & \multicolumn{2}{|c|}{ Distribution, wt 8} \\
\hline & wt 8 & GPT & & $0 i 1$ & Carbon \\
\hline \multicolumn{6}{|c|}{ MTU Packed Column Cell } \\
\hline Concentrate & 20.5 & 33.5 & 38.0 & 55 & 52 \\
\hline Tails & 79.5 & 7.0 & 9.0 & 45 & 48 \\
\hline Feed & 100.0 & 12.4 & 14.9 & $\overline{100}$ & $\overline{100}$ \\
\hline \multicolumn{6}{|l|}{ Deister Column Cell } \\
\hline Concentrate & 22.6 & 26.0 & 30.5 & 50 & 47 \\
\hline Tails & 77.4 & 7.5 & 10.0 & 50 & 53 \\
\hline Feed & 100.0 & 11.7 & 14.6 & 100 & 100 \\
\hline
\end{tabular}

Table 7-5. ANALYSIS OF HEAD SAMPLE OF TOTAL CONCENTRATE PRODUCED AT MTU

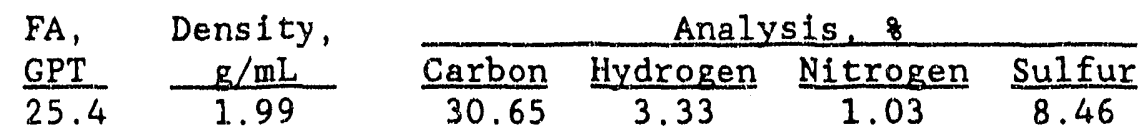




\section{Task 8. Profect Management and Reporting}

The objective of this task is to coordinate all aspects of the program among DOE, IGT, and the various subcontractors to insure that a cohesive program is maintained.

\section{Discussion}

During the quarter, IGT personnel prepared project status reports for June, July, and August. Also, IGT presented three papers at the 1991 Eastern Oil Shale Symposium on various project-related topics. Papers were also presented by IGT subcontractors MRI, TTU, and UN. The symposium was held November 12-14, in Lexington, Kentucky.

\section{FUTURE PIANS}

Work on the scheduled tasks will continue as planned.

\section{ACKNOWLEDGMENTS}

IGT acknowledges the significant work being conducted on this project by the individual subcontractors, their principal investigators, and colleagues -

MRI: Dr. C.W. Schultz

UK-CAER: Dr. B. K. Parekh

UN: Professor M. Misra

TTU: Professor W. P. Bonner 
Appendix A.

Results of the Preliminary Exergetic Evaluation of the PFH Proces Plant by Tennessee Technological University

Table A-1: THERMODYNAMIC PROPERTIES OF STREAMS IN THE PFH PLANT

Table A-2: HEAT LOSS, POWER SUPPLIED, EXERGY DESTRUCTION FLOW RATE, EXERGY DESTRUCTION RATIO, EXERGY DESTRUCTION TO SHALE EXERGY RATIO, AND EXERGETIC EFFICIENCY FOR PLANT COMPONENTS

Table A-3. STEAM GENERATION/CONSUMPTION (Positive values mean steam generation, negative values mean steam consumption) 


\section{Appendix A.}

RESULTS OF THE PRELIMINARY EXERGETIC EVALUATION OF THE PFH PROCESS PLANT BY TENNESSEE TECHNOIDGICAL UNIVERSITY

Table A-1: THERMODYNAMIC PROPERTIES OF STREAMS IN THE PFH PLANT

Table A-2: HEAT LOSS, POWER SUPPLIED, EXJARGY DESTRUCTION FLOW RATE, EXERGY DESTRUCTION RATIO, EXERGY DESTRUCTION TO SHALE EXERGY RATIO, AND EXERGETIC EFFJCIENCY FOR PLANT COMPONENTS

Table A-3. STEAM GENERATION/CONSUMPTION (Positive values mean steam generation, negative values mearl steam consumption) 


\begin{tabular}{|c|c|c|c|c|c|c|}
\hline $\begin{array}{l}\text { Stream } \\
\text { No. }\end{array}$ & 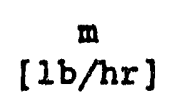 & $\begin{array}{c}T \\
{[F]}\end{array}$ & $\begin{array}{c}P \\
{[p s 1 a]}\end{array}$ & $\begin{array}{c}\mathrm{H} \\
\text { [Maritu/hr] }\end{array}$ & $\frac{\mathrm{s}}{[\mathrm{Mb} t \mathrm{~L} / \mathrm{hrR}]}$ & $\begin{array}{c}\mathbb{E} \\
{[\mathrm{MaBtu} / \mathrm{hr}]}\end{array}$ \\
\hline A & 2051416 & 60.0 & 1.0 & -5059.50 & 642.53 & 19311.60 \\
\hline W & 37951 & 60.0 & 1.0 & -260.15 & 34.03 & 0.04 \\
\hline B & 2014142 & 600.0 & 1.0 & -4859.24 & 1025.70 & 19344.65 \\
\hline C & 1080822 & 900.0 & 1.0 & -4016.67 & 571.87 & 4051.22 \\
\hline D & 1080822 & 650.0 & 1.0 & -4119.66 & 480.95 & 3995.47 \\
\hline $1 \mathrm{~A}$ & 160446 & 600 & 43.3 & -57.25 & 874.06 & 4061.41 \\
\hline 1 & 160446 & 180 & 620.0 & -143.68 & 770.43 & 4028.84 \\
\hline 2 & 563750 & 1400 & 620.0 & 451.78 & 3530.92 & 14684.37 \\
\hline 3 & 724195 & 1232.0 & 620.0 & 394.53 & 4429.70 & 18732.92 \\
\hline 4 & 1733417 & 900.0 & 615.0 & -592.52 & 5393.55 & 33699.63 \\
\hline 5 & 0 & 0.0 & 0.0 & 0.00 & 0.00 & 0.00 \\
\hline 6 & 1808642 & 600.0 & 610.0 & -1407.78 & 5196.17 & 33548.46 \\
\hline 7 & 563749 & 510.7 & 651.9 & -268.52 & 2985.74 & 14205.74 \\
\hline 10 & 563749 & 180.0 & 661.9 & -504.48 & 2686.05 & 14125.52 \\
\hline 16 & 1439753 & 460.4 & 600.0 & -1614.65 & 4630.55 & 26877.78 \\
\hline 17 & 1853 & 460.4 & 590.0 & -4.37 & 4.70 & 23.92 \\
\hline 19 & 1437899 & 460.4 & 595.0 & -1610.29 & 4627.80 & 26852.84 \\
\hline 20 & 1437899 & 130.0 & 590.0 & .2150 .91 & 3882.51 & 26699.53 \\
\hline 21 & 1050352 & 100.0 & 575.0 & -996.89 & 3473.67 & 22860.45 \\
\hline 22 & 3845 & 100.0 & 570.0 & -10.15 & 4.26 & 14.26 \\
\hline 23 & 1194 & 100.0 & 570.0 & -0.72 & 2.29 & 25.63 \\
\hline 24 & 1040956 & 100.0 & 570.0 & -956.34 & 3463.76 & 22820.2 \\
\hline
\end{tabular}




\begin{tabular}{|c|c|c|c|c|c|c|}
\hline \multicolumn{7}{|c|}{$\begin{array}{c}\text { Table A-1: THERMODYNAMIC PROPERTIES OF STREAMS IN THE PFH PLANT } \\
\text { (Part 2) }\end{array}$} \\
\hline $\begin{array}{l}\text { Stream } \\
\text { No. }\end{array}$ & $\min _{[1 \mathrm{~b} / \mathrm{hr}]}$ & $\stackrel{T}{[F]}$ & $\begin{array}{c}P \\
{[p s i a]}\end{array}$ & $\underset{\text { [Mastu/hr] }}{\mathrm{H}}$ & $\begin{array}{c}\mathbf{S} \\
{[\mathrm{Mb} t \mathrm{~L} / \mathrm{hrR}]}\end{array}$ & $\underset{[\mathrm{MBBtu} / \mathrm{hr}]}{\mathbf{R}}$ \\
\hline 25 & 1853 & 460.4 & 590.0 & .4 .37 & 4.70 & 23.92 \\
\hline 26 & 364020 & 100.0 & 30.0 & -92.47 & 314.93 & 6474.34 \\
\hline 27 & 6723 & 470.2 & 30.0 & -4.15 & 10.51 & 110.32 \\
\hline 30 & 15840 & 100.0 & 100.0 & -11.19 & 27.12 & 315.14 \\
\hline 31 & 115894 & 100.0 & 20.0 & -20.99 & 117.06 & 2100.14 \\
\hline 32 & 126097 & 100.0 & 19.5 & -22.70 & 124.63 & 2277.82 \\
\hline 33 & 132820 & 107.7 & 19.5 & -27.57 & 134.64 & 2387.66 \\
\hline 34 & 115894 & 158.5 & 100.0 & -18.91 & 114.47 & 2103.57 \\
\hline 35 & 14692 & 100.0 & 90.0 & -10.47 & 25.52 & 304.57 \\
\hline 36 & 900004 & 100.0 & 560.0 & -932.90 & 3333.97 & 20279.61 \\
\hline 37 & 918 & 200.0 & 20.0 & -6.26 & 0.89 & 0.00 \\
\hline 38 & 1083 & 100.0 & 20.0 & -0.22 & 1.31 & 22.22 \\
\hline 39 & 1.24903 & 100.0 & 19.5 & -21.98 & 121.79 & 2252.48 \\
\hline 40 & 91. & 90.0 & 100.0 & -0.62 & 0.09 & 0.00 \\
\hline 41 & 1302 & 100.0 & 90.0 & -1.25 & 1.71 & 10.65 \\
\hline 42 & 27153 & 100.0 & 18.0 & -38.80 & 38.80 & 189.27 \\
\hline 43 & 875234 & 100.0 & 550.0 & -901.61 & 3300.47 & 20100.91 \\
\hline 44 & 726 & 90.0 & 90.0 & -4.96 & 0.60 & 0.00 \\
\hline 45 & 355 & 90.0 & 560.0 & -2.42 & 0.34 & 0.00 \\
\hline 46 & 25124 & 100.0 & 550.0 & -33.80 & 29.59 & 180.95 \\
\hline 47 & 0 & 100.0 & 18.0 & 0.00 & 0.00 & 0.00 \\
\hline 48 & 26426 & 36.9 & 90.0 & -35.05 & 33.53 & 190.44 \\
\hline
\end{tabular}




\begin{tabular}{|c|c|c|c|c|c|c|}
\hline $\begin{array}{c}\text { Stream } \\
\text { No. }\end{array}$ & $\stackrel{m}{m}_{[1 \mathrm{~b} / \mathrm{hr}]}$ & $\stackrel{T}{[F]}$ & $\begin{array}{c}p \\
{[p s 1 a]}\end{array}$ & $\underset{\text { [MaBtu/hr] }}{\mathrm{H}}$ & $\begin{array}{c}S \\
{[\mathrm{Mbtu} / \mathrm{hr} \mathrm{R}]}\end{array}$ & $\begin{array}{c}\mathbf{E} \\
{[\mathrm{MMBtu} / \mathrm{hr}]}\end{array}$ \\
\hline 51 & 25258 & 99.7 & 14.7 & 0.10 & 6.18 & 202.64 \\
\hline 52 & 37822 & 99.7 & 14.7 & -50.47 & 54.28 & 272.09 \\
\hline 53 & 10670 & 100.0 & 14.7 & -11.67 & 15.16 & 82.99 \\
\hline 54 & 14676 & 99.7 & 14.7 & -100.02 & 14.24 & 0.04 \\
\hline 55 & 14676 & 99.7 & 14.7 & -100.02 & 14.24 & 0.04 \\
\hline 56 & 10492 & 99.7 & 14.7 & -40.86 & 12.76 & 1.45 \\
\hline 60 & 2706 & 100.0 & 100.0 & -0.96 & 3.38 & 55.40 \\
\hline 61 & 3789 & 100.0 & 20.0 & -1.18 & 4.87 & 77.53 \\
\hline 62 & 690516 & 100.0 & 14.7 & -529.94 & 597.40 & 13335.11 \\
\hline 63 & 60715 & 193.3 & 2041.2 & -51.57 & 392.29 & 1918.50 \\
\hline 64 & 51001 & 100.0 & 100.0 & -90.31 & 118.91 & 849.95 \\
\hline 65 & 30751 & 100.0 & 14.7 & -102.30 & 55.01 & 160.66 \\
\hline 67 & 1083 & 100.0 & 20.0 & -0.22 & 1.31 & 22.22 \\
\hline 68 & 495 & 100.0 & 250.0 & -3.38 & 0.48 & 0.00 \\
\hline 69 & 78846 & 297.7 & 64.7 & -449.72 & 195.46 & 26.00 \\
\hline 70 & 78846 & 297.7 & 64.7 & -521.60 & 100.53 & 3.44 \\
\hline 71 & 222829 & 120.8 & 14.7 & -1405.87 & 250.92 & 161.63 \\
\hline 72 & 10813 & 100.0 & 214.7 & -12.45 & 26.03 & 93.66 \\
\hline 73 & 205191 & 130.0 & 25.0 & -1392.15 & 209.86 & 1.16 \\
\hline 74 & 177402 & 130.5 & 20.0 & -1203.55 & 181.59 & 0.97 \\
\hline 75 & 192078 & 128.2 & 14.7 & -1303.57 & 195.85 & 1.00 \\
\hline 77 & 55882 & 100.0 & 320.0 & -111.89 & 134.37 & 1247.98 \\
\hline
\end{tabular}




\begin{tabular}{|c|c|c|c|c|c|c|}
\hline $\begin{array}{l}\text { Stream } \\
\text { No. }\end{array}$ & $\stackrel{\mathrm{m}}{\mathrm{m}} \mathrm{b} / \mathrm{hr}]$ & $\begin{array}{c}T \\
{[F]}\end{array}$ & $\begin{array}{c}P \\
\text { [ps1a] }\end{array}$ & $\underset{[\mathrm{MMBtu} / \mathrm{hr}]}{\mathbf{H}}$ & $\begin{array}{c}S \\
{[M b t u / h r R]}\end{array}$ & $\begin{array}{c}\mathbf{E} \\
\text { [MMBtu/hr] }\end{array}$ \\
\hline 78 & 1691323 & 60.0 & 14.7 & -6.85 & 2769.75 & 1.53 \\
\hline 79 & 1691323 & 90.5 & 17.4 & 5.62 & 2773.42 & 12.10 \\
\hline 80 & 97050 & 100.0 & 320.0 & -194.31 & 233.35 & 2167.36 \\
\hline 81 & 348343 & 100.0 & 550.0 & -358.84 & 1313.59 & 8000.16 \\
\hline 82 & 123892 & 100.0 & 214.7 & -100.74 & 939.92 & 3693.29 \\
\hline 83 & 223015 & 100.0 & 16.7 & -249.93 & 467.83 & 4256.36 \\
\hline 84 & 526891 & 100.0 & 550.0 & -542.77 & 1986.88 & 12100.75 \\
\hline 85 & 526891 & 137.5 & 661.9 & .523 .75 & 1995.79 & 12115.14 \\
\hline 86 & 123892 & 246.5 & 680.0 & -66.46 & 917.15 & 3739.41 \\
\hline 87 & 1436 & 250.0 & 20.0 & -7.99 & 3.60 & 0.42 \\
\hline 88 & 650784 & 1.71 .7 & 661.9 & -590.20 & 2924.74 & 15848.29 \\
\hline 89 & 38169 & 100.0 & 320.0 & -76.42 & 91.77 & 752.40 \\
\hline 90 & 2999 & 100.0 & 320.0 & -6.01 & 7.21 & 66.98 \\
\hline 91 & 237644 & 100.0 & 16.7 & .260 .39 & 495.68 & 4559.70 \\
\hline 92 & 192370 & 100.0 & 16.7 & -210.79 & 401.25 & 3691.03 \\
\hline 93 & 192370 & 242.4 & 320.0 & -197.86 & 376.20 & 3716.98 \\
\hline 94 & 73412 & 100.0 & 250.0 & -74.74 & 532.68 & 2276.98 \\
\hline 95 & 73412 & 226.8 & 679.9 & -57.86 & 522.30 & 2299.26 \\
\hline 96 & 45273 & 100.0 & 16.7 & -49.61 & 94.43 & 868.67 \\
\hline 97 & 60715 & 100.0 & 250.0 & -61.81 & 440,55 & 1883.19 \\
\hline 98 & 130281 & 488.8 & 614.7 & -834.86 & 197.58 & 16.36 \\
\hline 99 & 724195 & 180.0 & 661.9 & .648 .06 & 3450.52 & 18145.70 \\
\hline
\end{tabular}




\begin{tabular}{|c|c|c|c|c|c|c|}
\hline $\begin{array}{c}\text { Stream } \\
\text { No. }\end{array}$ & $\stackrel{m}{m}$ & $\begin{array}{c}T \\
{[\mathbf{F}]}\end{array}$ & $\begin{array}{c}P \\
{[p s 1 a]}\end{array}$ & $\begin{array}{c}\mathbf{H} \\
{[\mathrm{MMBtu} / \mathrm{hr}]}\end{array}$ & $\begin{array}{c}\text { S } \\
{[\mathrm{Mb} t u / \mathrm{hrR}]}\end{array}$ & $\begin{array}{c}E \\
{[\mathrm{MMBtu} / \mathrm{hr}]}\end{array}$ \\
\hline 100 & 130281 & 488.8 & 614.7 & -739.92 & 297.66 & 59.28 \\
\hline 101 & 195369 & 239.8 & 320.0 & -203.87 & 383.71 & 3783.79 \\
\hline 102 & 747971 & 401.7 & 320.0 & -3342.31 & 1719.63 & 3997.02 \\
\hline 103 & 747971 & 470.8 & 310.0 & -3292.99 & 1777.84 & 4016.09 \\
\hline 104 & 747971 & 800.0 & 300.0 & -3151.09 & 1911.63 & 4088.46 \\
\hline 105 & 747971 & 1535.0 & 300.0 & -2804.50 & 2129.87 & 4321.64 \\
\hline 106 & 748129 & 1535.0 & 300.0 & -2174.24 & 2591.83 & 4702.69 \\
\hline 107 & 894880 & 1099.2 & 300.0 & -3168.35 & 2878.57 & .4634 .04 \\
\hline 108 & 894880 & 841.7 & 290.0 & -3310.25 & 2783.41 & 4541.59 \\
\hline 109 & 894880 & 760.0 & 280.0 & -3354.28 & 2752.90 & 4513.42 \\
\hline 110 & 895042 & 900.0 & 280.0 & -3357.20 & 2764.84 & 4512.04 \\
\hline 111 & 895042 & 300.0 & 270.0 & -3785.46 & 2319.94 & 4314.98 \\
\hline 112 & 780239 & 100.0 & 260.0 & -3375.73 & 1668.72 & 4222.58 \\
\hline 113 & 525638 & 100.0 & 255.0 & -1640.83 & 1423.33 & 4221.27 \\
\hline 114 & 134127 & 100.0 & 250.0 & -136.55 & 973.23 & 4160.17 \\
\hline 115 & 552602 & 488.8 & 614.7 & -3138.44 & 1262.56 & 251.44 \\
\hline 116 & 146751 & 140.0 & 300.0 & -994.11 & 152.52 & 1.10 \\
\hline 117 & 254601 & 100.0 & 255.0 & -1734.89 & 247.08 & 0.83 \\
\hline 118 & 391015 & 100.0 & 250.0 & -1503.55 & 403.99 & 82.97 \\
\hline 119 & 0 & 0.0 & 0.0 & 0.00 & 0.00 & 0.00 \\
\hline 120 & 38169 & 85.2 & 17.4 & -76.42 & 105.37 & 845.33 \\
\hline 121 & 172126 & 130.0 & 580.0 & -1167.60 & 175.96 & 1.22 \\
\hline
\end{tabular}




\begin{tabular}{|c|c|c|c|c|c|c|}
\hline $\begin{array}{c}\text { Stream } \\
\text { No. }\end{array}$ & $\stackrel{\mathrm{m}}{\mathrm{m} / \mathrm{hr}]}$ & $\begin{array}{c}T \\
{[F]}\end{array}$ & $\begin{array}{c}P \\
\text { [psia] }\end{array}$ & $\begin{array}{c}\mathrm{y} \\
\text { [MMBEu/hr] }\end{array}$ & $\begin{array}{c}\mathrm{S} \\
{[\mathrm{Mbtu} / \mathrm{hrR}]}\end{array}$ & $\begin{array}{c}\mathrm{E} \\
\text { [MMBtu/hr] }\end{array}$ \\
\hline 122 & 4358 & 100.0 & 575.0 & -29.69 & 4.23 & 0.02 \\
\hline 123 & 176484 & 129.3 & 575.0 & -1197.29 & 180.20 & 1.23 \\
\hline 124 & 177402 & 130.5 & 20.0 & -1203.55 & 181.59 & 0.97 \\
\hline 125 & 114803 & 300.0 & 270.0 & -759.16 & 146.70 & 5.16 \\
\hline 126 & 1060805 & 3674.6 & 17.4 & -108.67 & 2471.69 & 899.91 \\
\hline 127 & 127156 & 297.7 & 64.7 & -725.27 & 315.22 & 41.92 \\
\hline 128 & 127156 & 297.7 & 64.7 & -841.20 & 162.13 & 5.54 \\
\hline 129 & 64105 & 488.8 & 614.7 & -364.08 & 146.46 & 29.17 \\
\hline 130 & 64105 & 488.8 & 614.7 & -410.79 & 97.22 & 8.05 \\
\hline 131 & 54110 & 60.0 & 14.7 & -0.22 & 88.61 & 0.05 \\
\hline 132 & 104175 & 240.0 & 614.7 & -695.17 & 124.34 & 2.95 \\
\hline 133 & 93757 & 488.8 & 614.7 & -532.48 & 21.4 .21 & 42.66 \\
\hline 134 & 10417 & 488.8 & 614.7 & -66.76 & 15.80 & 1.31 \\
\hline 135 & 38587 & 488.8 & 614.7 & -219.15 & 88.16 & 17.56 \\
\hline 136 & 38587 & 488.8 & 614.7 & -247.27 & 58.52 & 4.84 \\
\hline 137 & 21592 & 297.7 & 64.7 & -123.16 & 53.53 & 7.12 \\
\hline 138 & 21592 & 297.7 & 64.7 & -142.84 & 27.53 & 0.94 \\
\hline 139 & 1004932 & 90.0 & 17.4 & 3.21 & 1647.65 & 7.18 \\
\hline 140 & 55882 & 85.2 & 17.4 & -111.89 & 154.27 & 1237.64 \\
\hline 141 & 1726911 & 90.0 & 614.7 & -11783.00 & 1644.51 & 6.36 \\
\hline 142 & 1726911 & 397.4 & 614.7 & -11242.38 & 2423.73 & 142.04 \\
\hline 143 & 2012317 & 60.0 & 14.7 & -13793.88 & 1804.18 & 2.16 \\
\hline
\end{tabular}




\begin{tabular}{|c|c|c|c|c|c|c|}
\hline $\begin{array}{l}\text { Stream } \\
\text { No. }\end{array}$ & {$[1 \mathrm{~b} / \mathrm{hr}]$} & $\begin{array}{c}T \\
{[F]}\end{array}$ & $\begin{array}{c}P \\
{[p s 1 a]}\end{array}$ & $\underset{[\mathrm{MaBtu} / \mathrm{hr}]}{\mathrm{H}}$ & $\stackrel{\mathrm{S}}{[\mathrm{Mbtu} / \mathrm{hrR}]}$ & $\begin{array}{c}E \\
\text { [MABtu/hr] }\end{array}$ \\
\hline 144 & 2012317 & 94.0 & 14.7 & -13725.57 & 1931.51 & 4.30 \\
\hline 145 & 67678 & 488.8 & 614.7 & -384.37 & 154.63 & 30.79 \\
\hline 146 & 67678 & 488.8 & 614.7 & -433.69 & 102.64 & 8.50 \\
\hline 147 & 60413 & 488.8 & 614.7 & -387.13 & 91.62 & 7.58 \\
\hline 148 & 60413 & 488.8 & 614.7 & -343.11 & 138.03 & 27.49 \\
\hline 149 & 469712 & 297.7 & 64.7 & .3107 .39 & 598.92 & 20.47 \\
\hline 150 & 469712 & 297.7 & 64.7 & -2679.13 & 1164.41 & 154.86 \\
\hline 151 & 304551 & 60.0 & 14.7 & -2087.61 & 273.05 & 0.33 \\
\hline 152 & 304551 & 264.0 & 14.7 & -1738.18 & 802.09 & 74.83 \\
\hline 153 & 1265773 & 130.0 & 580.0 & -983.30 & 3710.43 & 26697.31 \\
\hline 154 & 1045994 & 100.0 & 575.0 & -967.11 & 3469.61 & 22860.60 \\
\hline 155 & 780239 & 300.0 & 270.0 & -3026.30 & 2173.24 & 4309.83 \\
\hline 156 & 1060805 & 854.0 & 17.4 & -1085.52 & 2081.01 & 126.09 \\
\hline 157 & 686391 & 90.0 & 17.4 & 2.19 & 1125.38 & 4.90 \\
\hline 158 & 724554 & 3674.6 & 17.4 & -74.23 & 1688.22 & 614.66 \\
\hline 159 & 724554 & 600.0 & 17.4 & -794.53 & 1376.48 & 56.36 \\
\hline 160 & 1060805 & 542.8 & 17.4 & -1180.46 & 1998.60 & 73.98 \\
\hline 216 & 368890 & 460.4 & 600.0 & -29.09 & 408.86 & 6578.94 \\
\hline 217 & 368890 & 460.4 & 590.0 & -29.09 & 408.86 & 6578.94 \\
\hline 221 & 215422 & 100.0 & 575.0 & -54.72 & 186.37 & 3831.41 \\
\hline 223 & 215422 & 100.0 & 570.0 & -54.72 & 186.37 & 3831.41 \\
\hline 225 & 368890 & 460.4 & 590.0 & -29.09 & 408.86 & 6578.94 \\
\hline
\end{tabular}




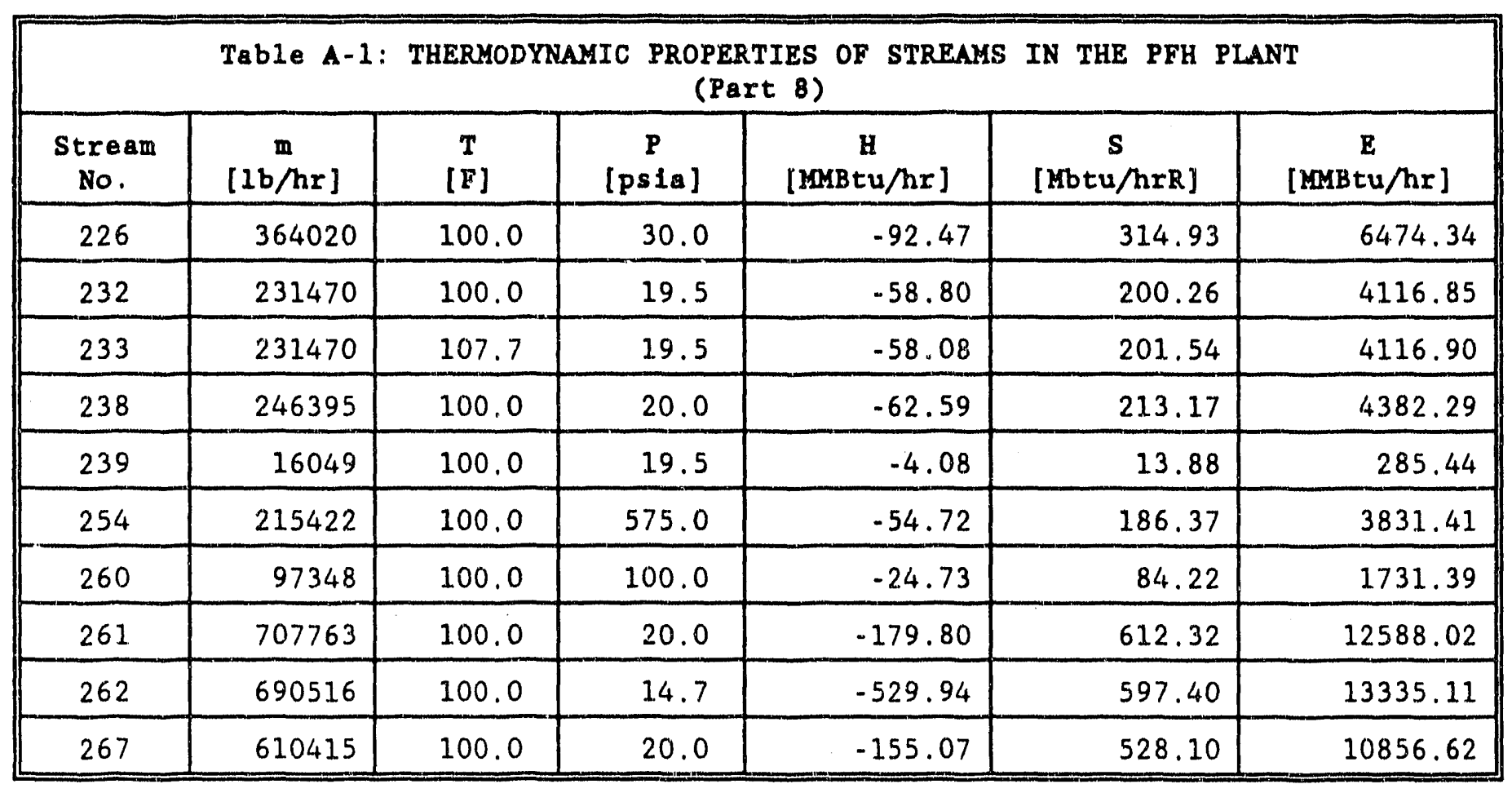




\begin{tabular}{|c|c|c|c|c|c|c|}
\hline \multicolumn{7}{|c|}{$\begin{array}{l}\text { Table A-2: HEAT LOSS, POWER SUPPLIED, EXERGY DESTRUCTION FLOW RATE, EXERGY } \\
\text { DESTRUC'TION RATIO, EXERGY DESTRUCTION TO SHALE EXERGY RATIO, AND EXERGETIC } \\
\text { EFFICIENCY FOR PLANT COMPONENTS }\end{array}$} \\
\hline COMPONENT & $\begin{array}{l}\text { HEAT } \\
\text { LOSS } \\
\text { [MW] }\end{array}$ & $\begin{array}{l}\text { POWER } \\
\text { [MW] }\end{array}$ & $\begin{array}{l}\text { EXERGY } \\
\text { DESTR. } \\
\text { [MW] }\end{array}$ & $\begin{array}{l}\text { EXD } \\
\text { RATIO } \\
{[8]}\end{array}$ & $\begin{array}{l}\text { EXD/ } \\
\text { EShale } \\
{[8]}\end{array}$ & $\begin{array}{l}\text { ERERG. } \\
\text { EFFIC. } \\
{[8]}\end{array}$ \\
\hline 1 Preheat & 104.00 & 0.00 & 34.63 & 5.46 & 0.61 & 21.83 \\
\hline 2 Retort & 50.59 & 8.24 & 104.00 & 16.39 & 1.84 & 97.68 \\
\hline 3 Cooling & 4.86 & 0.00 & 6.79 & 1.07 & 0.12 & 58.43 \\
\hline 4 Mixing $1 A+2=3$ & 0.00 & 0.00 & 3.77 & 0.59 & 0.07 & 99.93 \\
\hline 5 Heat Exchanger & 0.00 & 0.00 & 3.37 & 0.53 & 0.06 & 87.45 \\
\hline 6 Gas-0il Separator & 0.00 & 0.00 & 0.30 & 0.05 & 0.01 & 100.00 \\
\hline 7 Gas Cooler I & 0.00 & 0.00 & 5.17 & 0.81 & 0.09 & 88.50 \\
\hline 8 Knock-Out Drum I & 0.00 & 0.00 & 0.29 & 0.05 & 0.01 & 100.00 \\
\hline 9 Gas Cooler II & 0.00 & 0.00 & 0.97 & 0.15 & 0.02 & 39.28 \\
\hline 11 3-Phase Separator & 0.00 & 0.00 & 0.08 & 0.01 & 0.00 & 100.00 \\
\hline 12 Lean Oil. Scrubber & 0.77 & 0.00 & 0.81 & 0.13 & 0.01 & 99.99 \\
\hline 13 Lean Oil Stripper & 16.94 & 1.96 & 8.13 & 1.28 & 0.14 & 99.58 \\
\hline 14 Acid Gas Removal & 34.37 & 0.75 & 11.41 & 1.80 & 0.20 & 99.81 \\
\hline 15 Gas Compressor $31 / 34$ & 1.22 & 1.93 & 0.92 & 0.15 & 0.02 & 52.11 \\
\hline 16 Knock-Out Drum III & 5.27 & 0.00 & 0.48 & 0.08 & 0.01 & 99.92 \\
\hline 19 Claus \& Scot Units & 13.61 & 1.31 & 14.76 & 2.33 & 0.26 & 82.96 \\
\hline 20 Heavy Oil Flash Drum & 18.51 & 0.00 & 5.34 & 0.84 & 0.09 & 99.72 \\
\hline 21 Hydrogen Recovery & 0.00 & 0.00 & 14.68 & 2.31 & 0.26 & 99.37 \\
\hline $\begin{array}{l}22 \text { Rec. Gas Compr. } \\
82 / 86\end{array}$ & 10.05 & 21.16 & 7.64 & 1.20 & 0.13 & 63.89 \\
\hline $\begin{array}{l}23 \text { Rec. Gas Compr. } \\
84 / 85\end{array}$ & 0.00 & 5.87 & 1.65 & 0.26 & 0.03 & 71.87 \\
\hline $\begin{array}{l}24 \text { Rec. Gas Compr. } \\
94 / 95\end{array}$ & 5.10 & 10.57 & 4.05 & 0.64 & 0.07 & 61.73 \\
\hline $\begin{array}{l}25 \text { Compx } \text {. to H2 Plant } \\
92 / 93\end{array}$ & 7.63 & 12.02 & 4.42 & 0.70 & 0.08 & 63.26 \\
\hline 26 Mixing with Nat. Gas & 0.00 & 0.00 & 0.05 & 0.01 & 0.00 & 100.00 \\
\hline 27 Steam Addition 115 & 0.00 & 0.00 & 11.20 & 1.76 & 0.20 & 99.05 \\
\hline
\end{tabular}




\begin{tabular}{|c|c|c|c|c|c|c|}
\hline \multicolumn{7}{|c|}{$\begin{array}{l}\text { Table A-2: HEAT LOSS, POWER SUPPLIED, EXERGY DESTRUCTION FLOW RATE, EXERGY } \\
\text { DESTRUCTION RATIO, EXERGY DESTRUCTION TO SHALE EXERGY RATIO, AND EXERGETIC } \\
\text { EFFICIENCY FOR PLANT COMPONENTS (CONTInUEd) }\end{array}$} \\
\hline COMPONENT & $\begin{array}{l}\text { HEAT } \\
\text { LOSS } \\
\text { [MW] }\end{array}$ & $\begin{array}{l}\text { POWER } \\
{[\mathrm{MW}]}\end{array}$ & $\begin{array}{l}\text { EXERGY } \\
\text { DESTR. } \\
\text { [MW] }\end{array}$ & $\begin{array}{l}\operatorname{EXD} \\
\text { RATIO } \\
{[8]}\end{array}$ & $\begin{array}{c}\operatorname{EXD} / \\
\operatorname{EShale} \\
{[8]}\end{array}$ & $\begin{array}{l}\text { EXERG. } \\
\text { EFFIC. } \\
\text { [\%] }\end{array}$ \\
\hline $\begin{array}{l}28 \text { Heat Exchanger } \\
102 / 103\end{array}$ & 0.00 & 0.00 & 0.95 & 0.15 & 0.02 & 85.52 \\
\hline $\begin{array}{l}29 \text { Feed Prod theat } \\
\text { Exchanger }\end{array}$ & 0.00 & 0.00 & 5.88 & 0.93 & 0.10 & 78.29 \\
\hline 30 Reformer Furnace & 0.00 & 0.00 & 150.55 & 23.72 & 2.66 & 56.13 \\
\hline 31 Quench Water & 0.00 & 0.00 & 20.44 & 3.22 & 0.36 & 98.52 \\
\hline $\begin{array}{l}32 \text { Heat Exchanger } \\
108 / 109\end{array}$ & 0.00 & 0.00 & 2.42 & 0.38 & 0.04 & 70.65 \\
\hline 33 Shift Conversion & 0.86 & 0.00 & 0.40 & 0.06 & 0.01 & 99.97 \\
\hline $\begin{array}{l}34 \text { Heat Exchanger } \\
110 / 111\end{array}$ & 0.00 & 0.00 & 18.37 & 2.89 & 0.32 & 68.20 \\
\hline 35 Knock-Out Drum IV & 0.00 & 0.00 & 0.00 & 0.00 & 0.00 & 100.00 \\
\hline $\begin{array}{l}36 \text { Heat Exchanger } \\
111 / 112\end{array}$ & 0.00 & 0.00 & 3.73 & 0.59 & 0.07 & 85.40 \\
\hline 37 Knock-Out Drum V & 0.00 & 0.00 & 0.14 & 0.02 & 0.00 & 99.99 \\
\hline $\begin{array}{l}38 \text { Absorber/ } \\
\text { Regenerator }\end{array}$ & 22.85 & 1.01 & 1.21 & 0.19 & 0.02 & 99.90 \\
\hline $\begin{array}{l}39 \text { Compr. to Des, \& } \\
\text { Hydr. }\end{array}$ & 15.92 & 19.92 & 9.57 & 1.51 & 0.17 & 51.96 \\
\hline $\begin{array}{l}40 \text { Desalting \& } \\
\text { Hydrotreating }\end{array}$ & 148.71 & 5.10 & 74.95 & 11.81 & 1.32 & 98.23 \\
\hline $\begin{array}{l}41 \text { Sour Water \& NH3 } \\
\text { Recover }\end{array}$ & 3.57 & 3.50 & 2.94 & 0.46 & 0.05 & 94.66 \\
\hline $\begin{array}{l}42 \text { Natural Gas } \\
\text { Throttling }\end{array}$ & 0.00 & 0.00 & 5.10 & 0.80 & 0.09 & 99.17 \\
\hline 43 Fired Heater & 0.00 & 0.00 & 92.39 & 14.56 & 1.63 & 60.29 \\
\hline 44 Air Fan $78 / 79$ & 0.00 & 3.85 & 0.75 & 0.12 & 0.01 & 80.49 \\
\hline 45 Sum & 464.83 & 97.19 & 634.69 & 100.00 & 11.21 & $\cdots$ \\
\hline 46 Exergy Losses & $\cdots$ & $\cdots$ & 113.95 & $\cdots$ & $\cdots$ & $\cdots$ \\
\hline 47 Total Plant & 464.87 & 97.19 & 748.63 & $\ldots$ & $\cdots$ & 84.86 \\
\hline
\end{tabular}


Table A-3. STEAM GENERATION/CONSUMPTION (Positive values mean steam generation, negative values mean steam consumption)

\begin{tabular}{|c|c|c|}
\hline Component & $\begin{array}{c}\text { Heat Transfer } \\
{[\text { MMBtu/hr] }}\end{array}$ & $\begin{array}{c}\text { Mass Flow Rate } \\
{[\text { [b/hr] }}\end{array}$ \\
\hline
\end{tabular}

HP STEAM

\begin{tabular}{|l|c|c|}
\hline Claus \& Scot Units 132/133 & 95.9 & 93757.1 \\
\hline Reformer Furnace & 94.9 & 130281.5 \\
\hline Heat Exchanger 108/109 & 44.0 & 60413.3 \\
\hline Claus \& Scot Units 135/136 & -28.1 & -38587.0 \\
\hline Lean Oil Stripper & -46.7 & -64104.9 \\
\hline Heat Exchanger 102/103 & -49.3 & -67678.3 \\
\hline Totals & 110.7 & 114081.7 \\
\hline \hline
\end{tabular}

LP STEAM

\begin{tabular}{||l|c|c|}
\hline Heat Exchanger 110/111 & 428.3 & 469712.4 \\
\hline Acid Gas Removal & -115.9 & -127156.4 \\
\hline Claus \& Scot Units 137/138 & -19.7 & -21592.1 \\
\hline Absorber/Regenerator & -71.9 & -78845.7 \\
\hline Totals & 220.7 & 242118.3 \\
\hline \hline
\end{tabular}

FEED WATER PREHEATING

\begin{tabular}{|l|r|r}
\hline Gas Cooler I & 540.6 & 1726910.6 \\
\hline
\end{tabular}

COOLING WATER

\begin{tabular}{|l|c|c|}
\hline Gas Cooler II & 68.3 & 2012316.9 \\
\hline Heat Exchanger $111 / 112$ & 349.4 & 304550.9 \\
\hline
\end{tabular}


Appendix B.

DEVELOPMENT OF THERMOECONOMIC FACTORS FOR THE PFH

PLANT BY TENNESSEE TECHNOLOGICAL UNIVERSITY 
Tennessee Technological University is conducting an initial thermoeconomic evaluation of the PFH plant. The goals of this study are to identify thermodynamic losses, to assist in developing cost-effective solutions to reduce those losses, to improve the understanding of the cost/benefit tradeoffs in the design, and to facilitate future PFH process optimization studies.

The variables to be used for the evaluation of each plant component will be based upon the following variables:

1. The cost of exergy destruction in the $k$-th system. In this study, this cost will be calculated from the following relationship:

$$
\dot{D}_{k}=C_{F, k} \dot{B}_{\mathfrak{D}, k}
$$

$\dot{\boldsymbol{B}}_{\mathrm{D}, \mathrm{k}}$ is the rate of exergy destruction in the $\mathrm{k}$-th system and $\dot{\mathrm{D}}_{\mathbf{k}}$ represents the cost of the fuel used to cover the exergy destruction in the system.

2. The relative cost difference $\left(d_{k}\right)$ between average cost per exergy unit of product and average cost per exergy unit of fuel is

$$
d_{k}=\frac{c_{p, k}-c_{F, k}}{c_{F, k}}=\frac{\dot{D}_{k}+z_{k}}{c_{F, k} \dot{B}_{p, k}}=\frac{1-\zeta_{k}}{\zeta_{k}}+\frac{z_{k}}{c_{F, k} \dot{E}_{p, k}}
$$

This equation reveals the real cost sources in the $k$-th system, which are (a) the capital costs $\left(\dot{z}_{k}\right)$ and (b) the exergy destruction in the system, as expressed by the first term on the right side of the equation. In general, the higher the relative cost difference $d_{k}$, the more attention should be paid to the $k$-th system.

3. The thermoeconomic factor $f_{k}$ is

$$
f_{k}=\frac{\dot{z}_{k}}{z_{k}+D_{k}}
$$

which expresses the contribution of the capital costs $\left(\dot{z}_{x}\right)$ to the relative cost difference $d_{k}$.

4. For the evaluation of heat exchangers from the thermoeconomic viewpoint, the variable $r_{k}$ defined by 


$$
r_{k}=\frac{z_{k}}{E_{p, k}}
$$

Is used in addition to the other variables discussed above. This variable states the capital costs required to transfer a unit of exergy to the cold stream of the heat exchanger.

All these variables w1ll be used to determine the shanges in the PFH plant structure or in a design variable (temperature, pressure, etc.) which could lead to a decrease in the costs of the final products. 

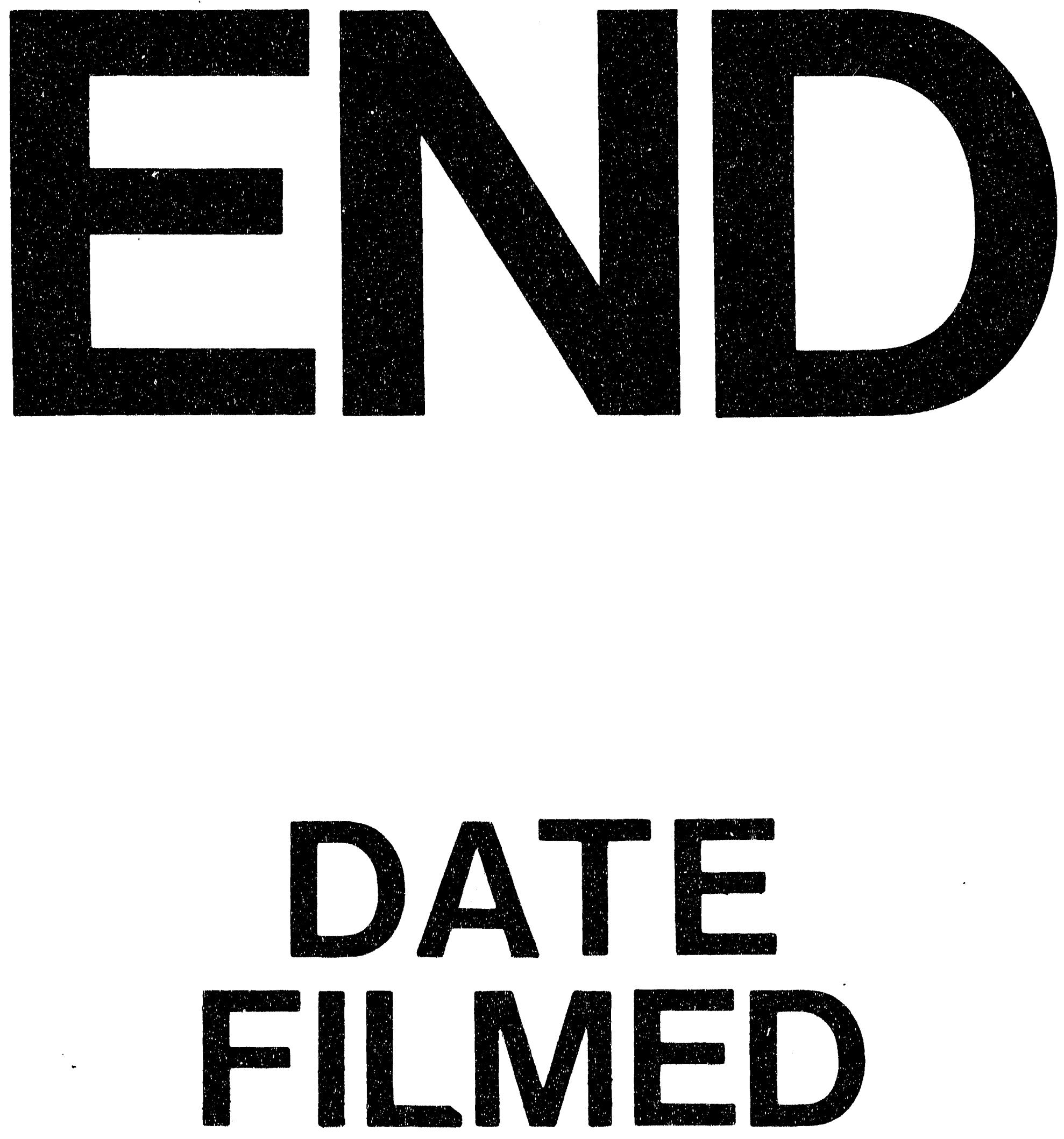

㪯

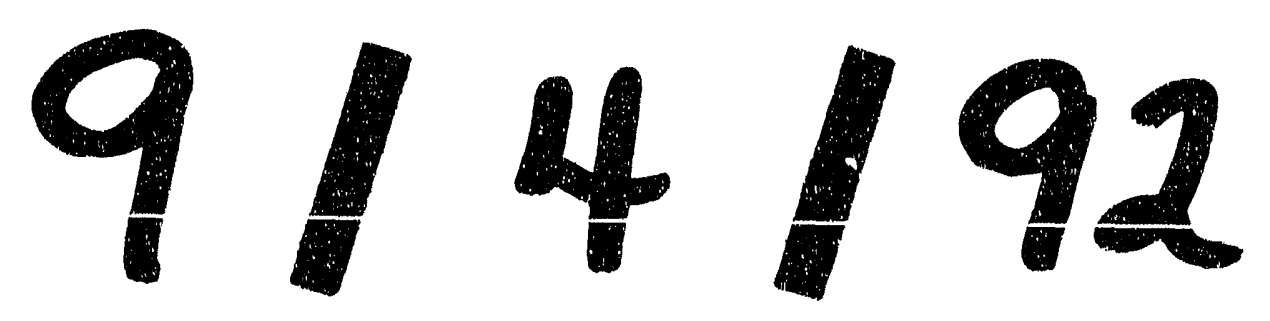


